\title{
WestVirginiaUniversity
}

THE RESEARCH REPOSITORY @ WVU

Graduate Theses, Dissertations, and Problem Reports

2012

\section{Energy saving expert system for West Virginia K-12 schools}

Karthik Reddy Dandu

West Virginia University

Follow this and additional works at: https://researchrepository.wvu.edu/etd

\section{Recommended Citation}

Dandu, Karthik Reddy, "Energy saving expert system for West Virginia K-12 schools" (2012). Graduate Theses, Dissertations, and Problem Reports. 4845.

https://researchrepository.wvu.edu/etd/4845

This Thesis is protected by copyright and/or related rights. It has been brought to you by the The Research Repository @ WVU with permission from the rights-holder(s). You are free to use this Thesis in any way that is permitted by the copyright and related rights legislation that applies to your use. For other uses you must obtain permission from the rights-holder(s) directly, unless additional rights are indicated by a Creative Commons license in the record and/ or on the work itself. This Thesis has been accepted for inclusion in WVU Graduate Theses, Dissertations, and Problem Reports collection by an authorized administrator of The Research Repository @ WVU. For more information, please contact researchrepository@mail.wvu.edu. 
ENERGY SAVING EXPERT SYSTEM FOR WEST VIRGINIA K-12 SCHOOLS

Karthik Reddy Dandu

Thesis Submitted to the College of Engineering and Mineral Resources at West Virginia University

in partial fulfillment of the requirements

for the degree of

Master of Science

In

Mechanical Engineering

Approved by

Dr. Kenneth H. Means, Ph.D., P.E., Committee Chairperson

Dr. Larry E. Banta, Ph.D., P.E.

Dr. Bhaskaran Gopalakrishnan, Ph.D., P.E., CEM

Department of Mechanical and Aerospace Engineering

Morgantown, West Virginia

2012

Keywords: K-12 Schools, Energy, Expert System

Copyright 2012 


\title{
ABSTRACT \\ ENERGY SAVING EXPERT SYSTEM FOR WEST VIRGINIA K-12 SCHOOLS
}

\author{
Karthik Reddy Dandu
}

Investments on energy efficiency measures adopted by K-12 School boards across West Virginia (WV) have not always been economically successful. Since finances play an important role, and school boards have limited resources to invest on energy efficiency measures, the school boards are left with difficult choices on how best to use their funds. An expert system developed in this thesis work aims to assist the WV School Boards to examine the feasibility of implementing different types of energy measures. The expert system acquires data from the user and uses the information to provide the user with savings, installation and payback advice. Many energy efficiency measures were examined for this thesis but only the measures which could have faster paybacks (mostly less than 10 years as required by WV state law) were considered and implemented in the system. Many parameters such as fuel types, climate zones and cost of the fuel were considered in the energy saving options. Some WV school systems have already been studied by the WVU, Center for Building Energy Efficiency. Some energy saving measures have been employed as test cases during the expert system development, with less than $10 \%$ difference in results. The expert system developed in this thesis is user friendly and can be upgraded in the future as new measures are included. 
Dedication

This Thesis is dedicated to my Parents, Dr. Ken Means and all those people who have inspired me in my life to be where I stand today. 


\section{Acknowledgements}

I am very thankful to my advisor, Dr. Ken Means, for giving me a chance to work for him, for his support and guidance during my research work, allowing me to work with the undergraduate students for the senior engineering projects and also becoming one of my role models in life. I am also grateful to my committee members Dr. Banta and Dr. Gopala, for their valuable suggestions and time. West Virginia Division of Energy for giving us the chance to work on school energy projects.

I would also like to thank my parents, Goverdhan and Anantha Dandu, for supporting me throughout my life. I am thankful to god that I have got such a lovely parents. My father's words, if you possess 'Honesty and Patience you might not win today but you will one day for sure' have always inspired me.

I am thankful to my friend Anand Kadiyala for his idea to make a GUI for my thesis, WVU IAC team members for calculations, Srikanth Parupati and ondrej for their help with my programming, and all my friends from WVU and SASTRA who have been with me in good and bad times. 
Table of Contents

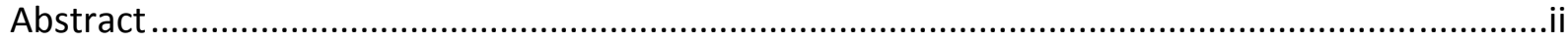

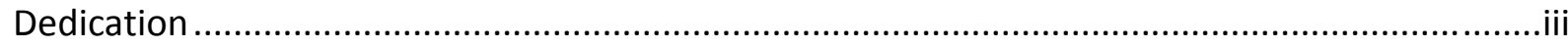

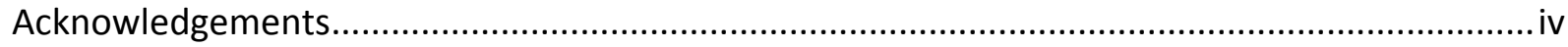

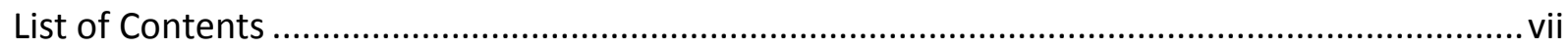

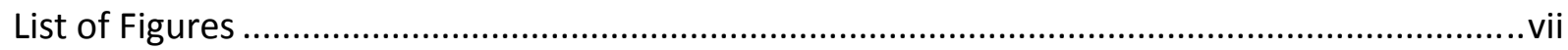

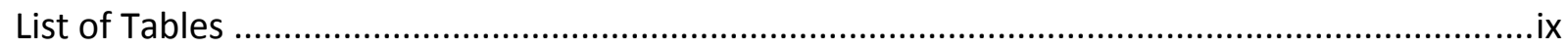

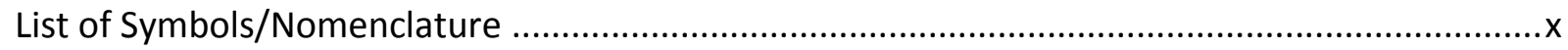

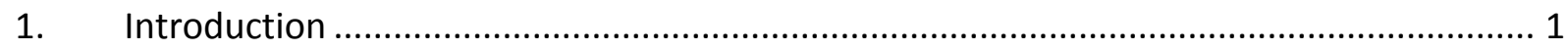

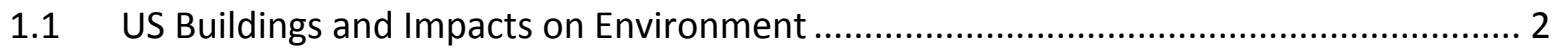

1.2 Work on West Virginia (WV) K-12 Schools Energy Efficiency ...................................... 5

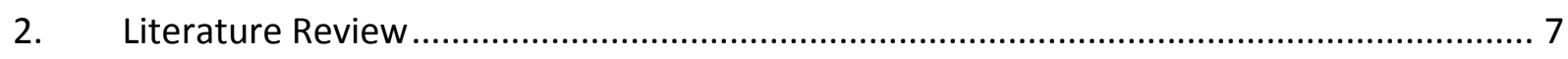

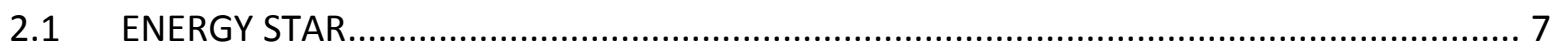

2.2 ASHRAE 90.1

2.3 Advanced Energy Design Guide for K-12 School Buildings (AEDG K-12) ...................... 11

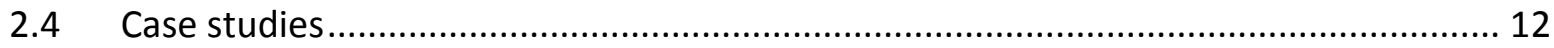

2.5 Schools Using ENERGY STAR Recommendations ..................................................... 12

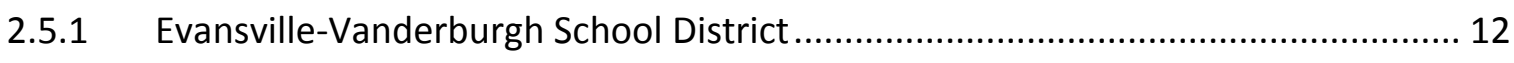

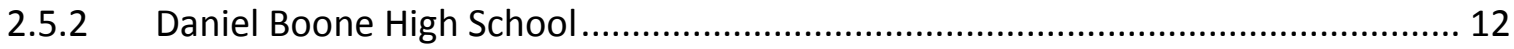

2.6 Schools Using AEDG (K-12) Recommendations and LEED certified ............................. 13

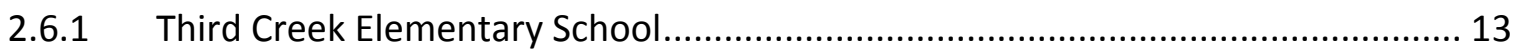

2.7 Schools Using WVU Recommendations ............................................................... 13

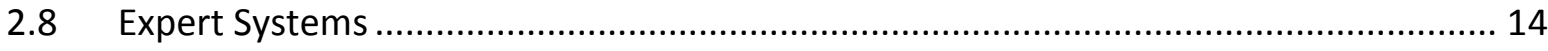

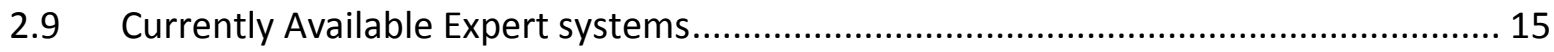

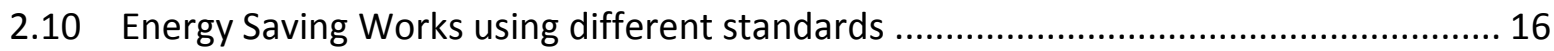

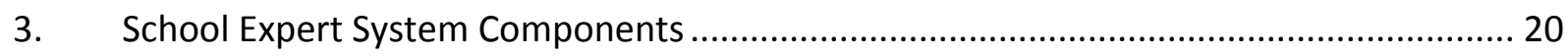




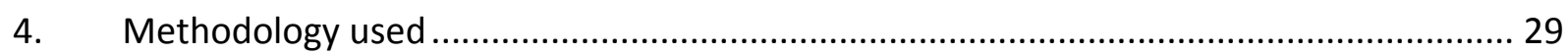

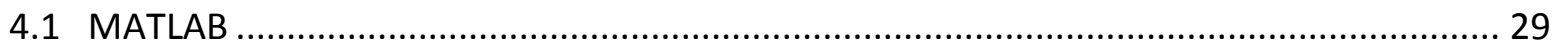

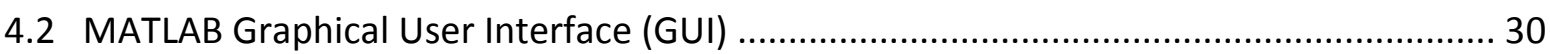

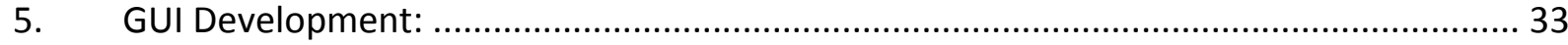

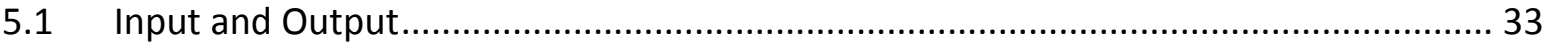

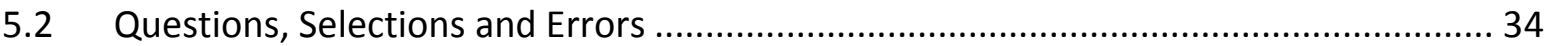

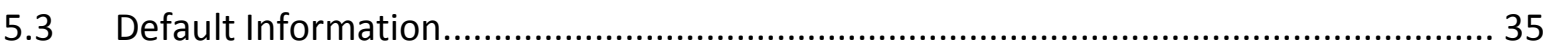

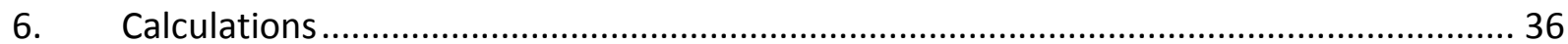

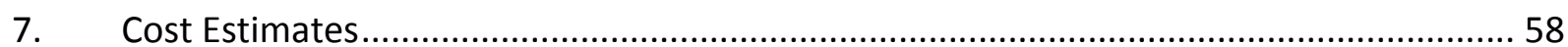

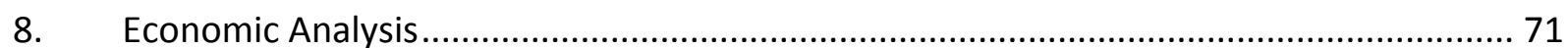

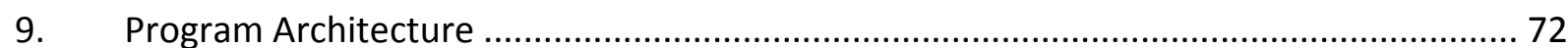

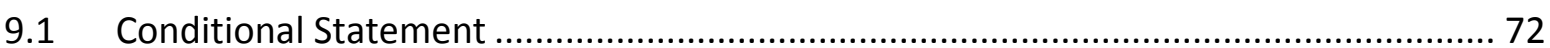

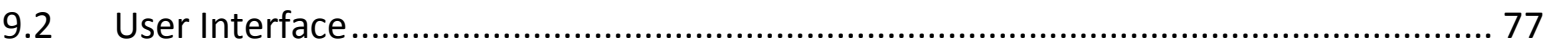

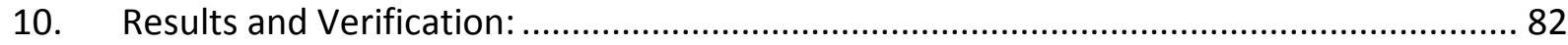

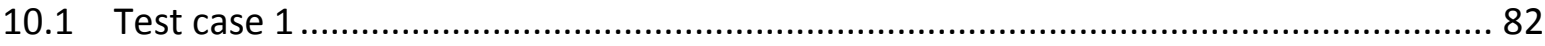

10.2 Test Case 2

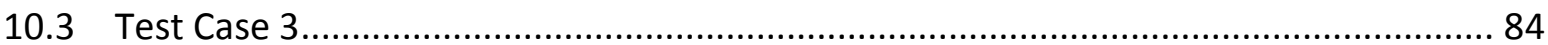

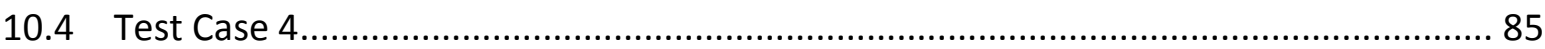

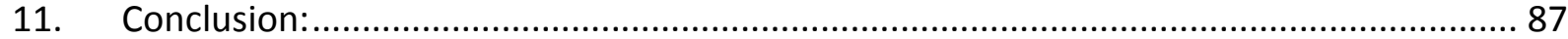

12. Future Work:

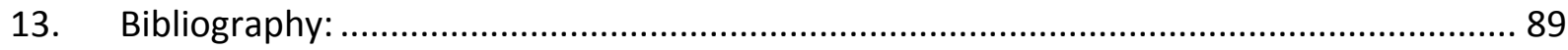

Appendix A: Expert System Software Code for Main Case and Roof Insulation ..........................93 


\section{List of Figures}

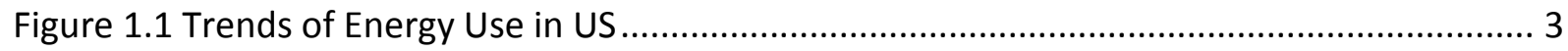

Figure $1.2 \mathrm{CO} 2$ Emissions trends by buildings in different countries ......................................... 4

Figure 1.3 Measuring the Intake Air flow through the Dampers .............................................. 6

Figure 1.4 Measuring Lighting Levels in Pleasants County Middle School ................................... 6

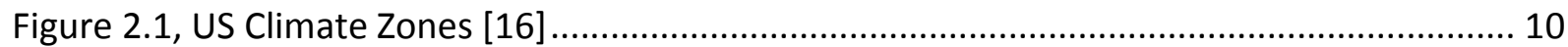

Figure 2.2, Energy Consumption of K-12 Schools by Climate Zone [16] ................................... 11

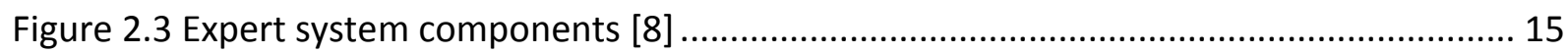

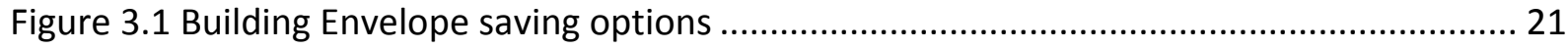

Figure 3.2 Checking the Belmont Elementary School Windows during Audit ........................... 21

Figure 3.3 Brandywine Elementary School with Skylights ...................................................... 23

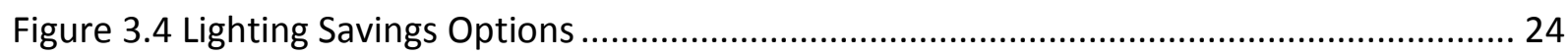

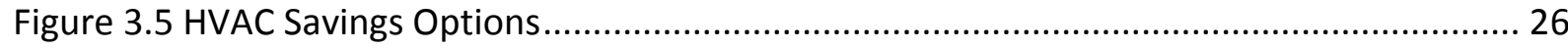

Figure 3.6 Service Water Heater Savings Options .................................................................. 27

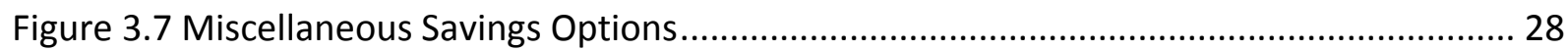

Figure 3.8 Computer Room in Bethlehem Elementary School Ohio County, WV ....................... 28

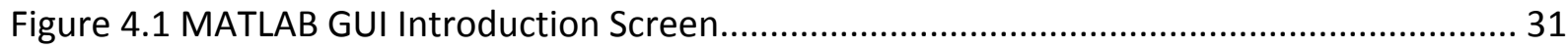

Figure 6.1 Graph for Natural Gas (\% Excess air Vs. Efficiency) ................................................... 50

Figure 6.2 Graph for Fuel Oil (\%Excess air Vs. Efficiency) ........................................................... 51

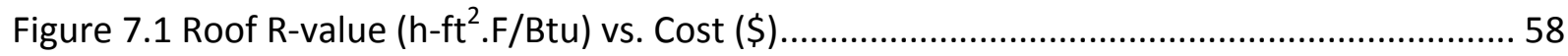

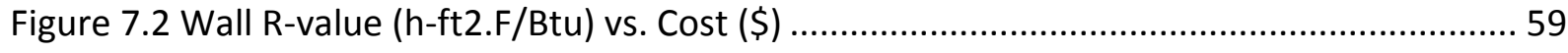

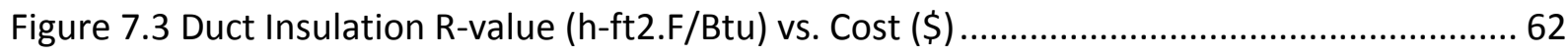

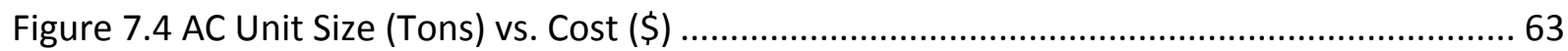

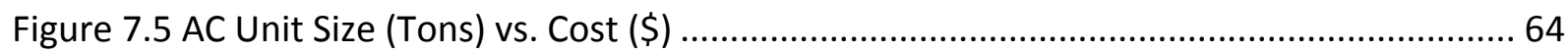

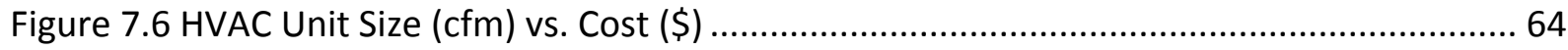

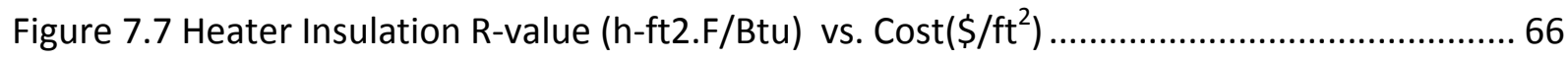

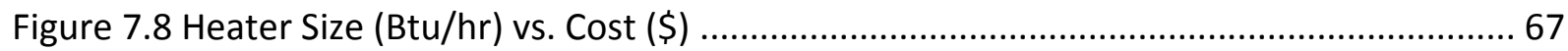

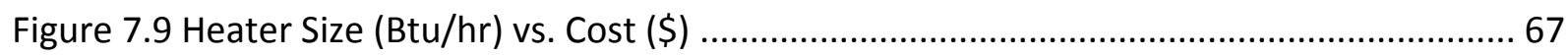

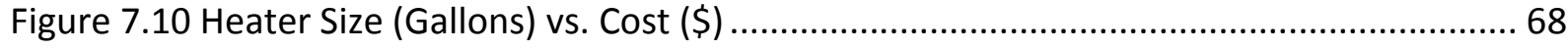


Figure 9.1 Flow chart for default values upon selecting climate zone

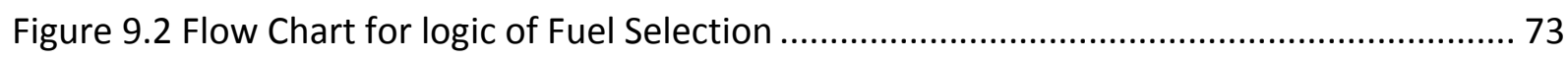

Figure 9.3 Flow chart showing logic for window Floor and type............................................. 74

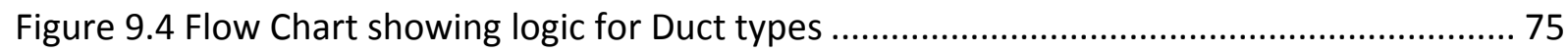

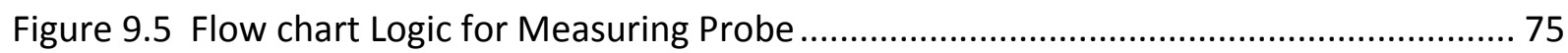

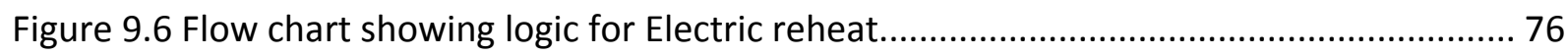

Figure 9.7 Flow chart showing logic for ENERGY STAR EZ GPO Tool ......................................... 76

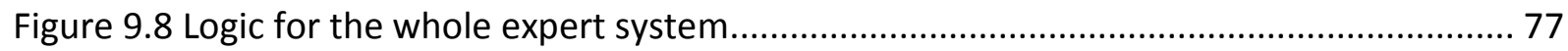

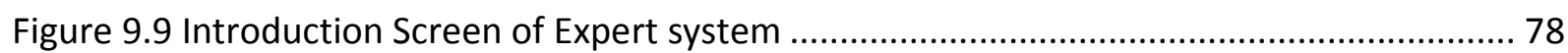

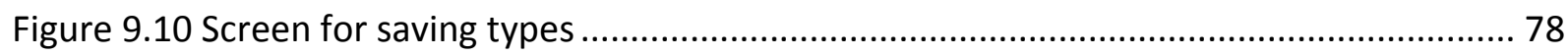

Figure 9.11 Screen showing the selection of Building Envelope Savings .................................... 79

Figure 9.12 Screen showing the questions for Roof Insulation .............................................. 80

Figure 9.13 The error dialogue showing value to be more than 1 .......................................... 81

Figure 9.14 The error dialogue showing enter only numbers ................................................ 81

Figure 9.15 Warning Dialogue showing electric heaters are $100 \%$ efficient............................. 81

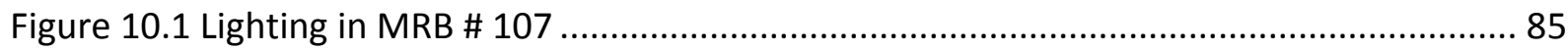




\section{List of Tables}

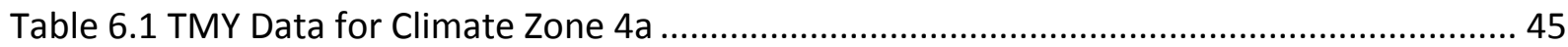

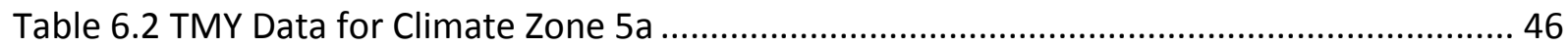

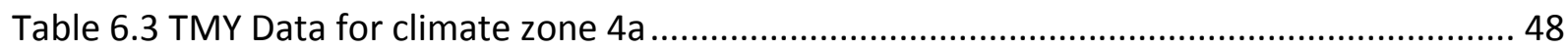

Table 6.4 MY Data for Climate Zone 5a ................................................................................. 48

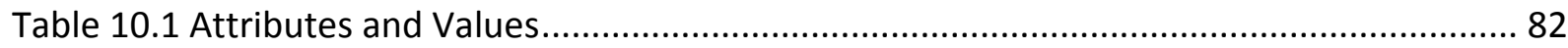

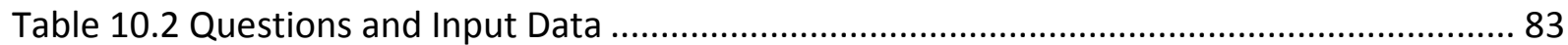

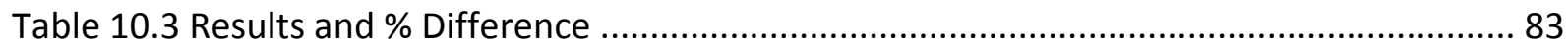

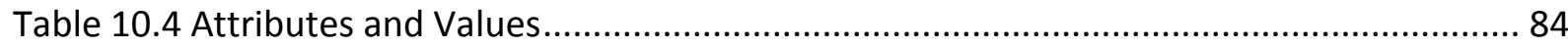

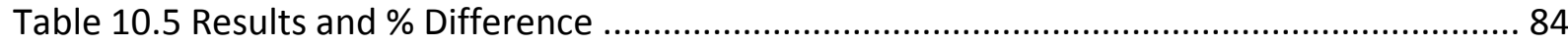

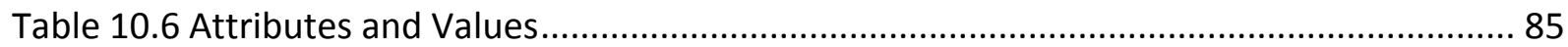

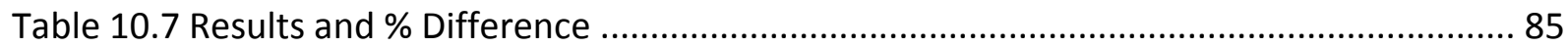

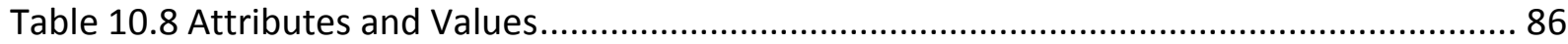

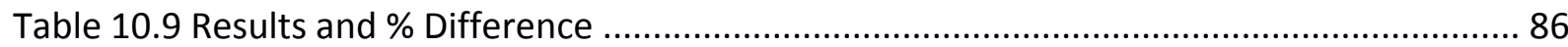




\section{List of Symbols/Nomenclature}

$\$$

Dollars

\#

Number

$\%$

Percent

${ }^{\circ} \mathrm{F}$

Degrees Fahrenheit

$\mathrm{Btu} / \mathrm{hr}$

British thermal unit per hour

$\mathrm{Ft}$

Feet

Ft2

Square feet

Cu.ft. $/ \mathrm{ft}^{3}$

Cubic foot

HV

Heating Value

ASHRAE

American Society of Heating Refrigeration and Air Conditioning Engineers

DOE

Department of Energy

AEDG

Advanced Energy Design Guide

$\mathrm{KW}$

Kilowatt

KWh

Kilowatt hour

gpm

gallons per minute

$\mathrm{Btu} / \mathrm{h} . \mathrm{ft}^{2}{ }^{\circ} \mathrm{F}$

British thermal unit per hour-square feet-degree Fahrenheit

h. $\mathrm{ft}^{2} \cdot{ }^{\circ} \mathrm{F} / \mathrm{Btu}$

Hour-square feet-degree Fahrenheit per British thermal unit

Btu/Gallon

British thermal unit per Gallon

$\mathrm{Btu} / \mathrm{kWh}$

British thermal unit per Kilowatt hour

$\mathrm{Btu} / \mathrm{ft}^{3}$

British thermal unit per cubic foot

HDD

Heating Degree Days

CDD

Cooling Degree Days

HLoad

Heating Load Reduction 


\section{Introduction}

As the world has taken an on the challenge of reducing green house gas emissions and dealing with climate change, engineers have taken several measures to come up with answers and have several options in which Energy Efficiency has become one of the best options. Energy Efficiency is a wide concept and there are several fields in which this concept can be applied and building energy efficiency is one of them. Building types consist of agricultural, commercial, residential, educational, government, industrial, military, parking and storage, religious buildings, transit stations and others.

In this research only $\mathrm{K}-12$ schools are considered and examined. K-12 schools are again classified as Elementary, middle and high schools. Each school has its own approach and strategy with which the maximum amount of energy can be saved.

The objective of this research is to provide an expert system program which gives the West Virginia school boards the energy and money saved, cost for installation and payback period by installing the energy reduction measures considered. The expert system program developed in this study is used to determine if a recommendation to save energy is feasible and has the fastest payback period considering the installation cost of the recommendation selected. In the system, the user has to enter data in the form of answers to a series of questions and also make some selections. These were designed to minimize information and knowledge needed by the schools to give accurate results. If the user enters any undesirable characters or numbers which cannot be considered as parameters for the results to be shown, then the expert system warns and displays a message so that the user enters an appropriate 
value. If the user selections change then the expert system changes the results accordingly. In this research, various possible energy saving capabilities and calculations associated with it which have a fastest payback period were examined.

\subsection{US Buildings and Impacts on Environment}

\section{- Energy Use}

There are around 223,114 establishments/businesses, 128 million residential housing units as of 2007 and 4.9 million commercial buildings and around 124,110 colleges, universities, public and private primary and secondary schools.

Buildings consume 38.9 percent of total US energy consumption as of 2005 in which 46.3 percent goes to commercial buildings and 53.7 percent by residential buildings.

As of 2006, 36 percent of natural gas and 72 percent of total US electricity consumption is used by buildings, and this number may rise to 75 percent by 2025 and in that 75 percent, commercial buildings make 49 percent and residential make up 51 percent.

Energy costs of K-12 schools nationwide amounts to \$8 billion annually and each year the gas bills and electricity bills which schools spend on each student is approximately $\$ 75$ and $\$ 130$ respectively. On an average of $10 \mathrm{kWh}$ of electricity and 50 cubic feet of natural gas per square foot is used annually by K-12 schools. In 2008, a typical school district paid $\$ 1.25 /$ square foot annually for energy. $\$ 1 \mathrm{M}$ is paid annually on energy by a mid-sized school district with 800,000 square feet of space. 
Growth in Buildings Energy Use Relative to Other Sectors
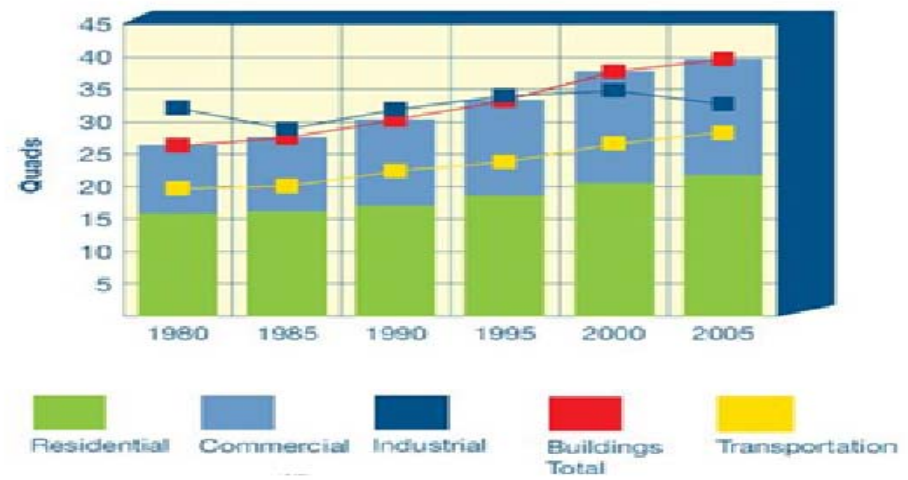

Predominance of Electiricity as Buildings Energy Source
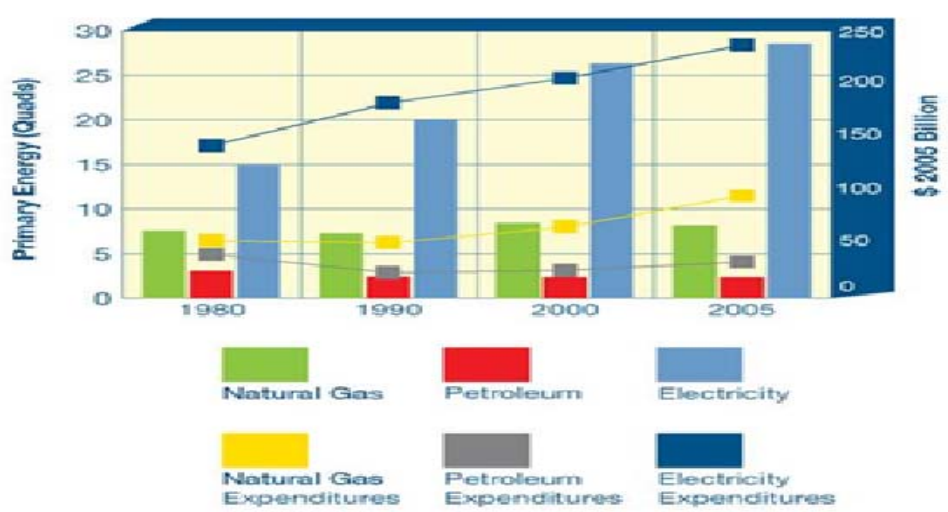

Figure 1.1 Trends of Energy Use in US

- Air and Atmosphere

In the US, buildings contribute to almost 40 percent of carbon dioxide $\left(\mathrm{CO}_{2}\right)$ emissions and 18 percent of it comes from commercial sector, 20.8 percent from residential sector and as of 2005, US buildings account to around 9 percent of global $\mathrm{CO}_{2}$ emissions i.e. 2,319 million metric tons of $\mathrm{CO}_{2}$. 


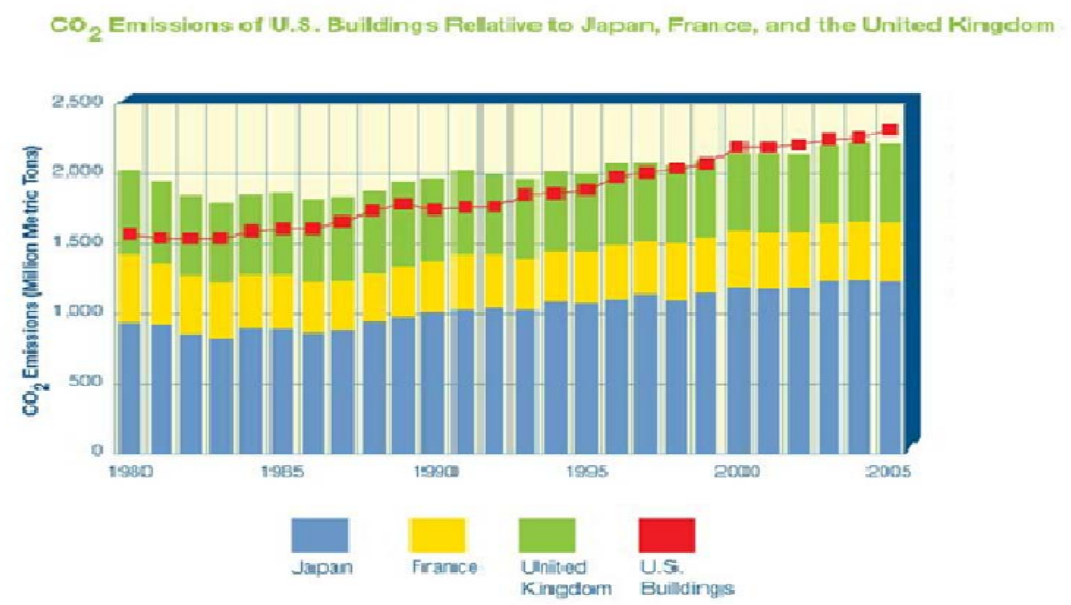

Figure 1.2 $\mathrm{CO} 2$ Emissions trends by buildings in different countries

- Waste

In 2007 US generated a municipal solid waste (MSW) of 254 million tons, the buildings construction and demolition(C\&D) debris totals approximately 160 million tons/year which accounts to 26 percent of total non-industrial waste generation, by combining both the C\&D and MSW there is about two-thirds of all non-industrial solid waste. 


\subsection{Work on West Virginia (WV) K-12 Schools Energy Efficiency}

Energy Efficiency projects on WV K-12 schools are funded by the WV Division of Energy (DOE) and these school projects are handled by West Virginia University (WVU). In WVU these projects are worked by senior engineering students and grad students as a part of their senior project under guidance of Dr. Ken Means for a semester. Before the project starts the school board of a county sends in two years of energy bills, which are entered in the ENERGY STAR's Portfolio Manager Website. After the bills are entered in the website, each school gets a rating from 1-100, the greater the number the better the school is performing and vice versa. Out of all the schools in a county the two least performing schools are chosen for the project. As a part of their work, first the students make visits to the schools and they perform an energy audit on the schools and gather the required information for calculations. The school board provides them with the school building drawings and other required information if needed. During the semester classes the students perform the calculations and if required they re-visit the schools and perform another energy audit. By the end of the semester the students calculate the energy saving potential for various recommendations and their installation and payback period details and present it to the school board. A copy of the report is also sent to the WV DOE and school board. After that the school has to send the report to the WV Department of Education for the funds to be sanctioned. In this whole process there are some issues which have gone unnoticed 
- Not all possible energy saving strategies are mentioned in the recommendations as the time for each school project is not long. Not all information needed is provided by schools or there is some information missing.

- After the recommendations are provided to the schools the funds needed for retrofitting or renovation, takes time to be sanctioned from Department of Education.

- On the other hand, the other energy saving strategies which could be applied with minimal installation costs are also not applied in any of the schools.

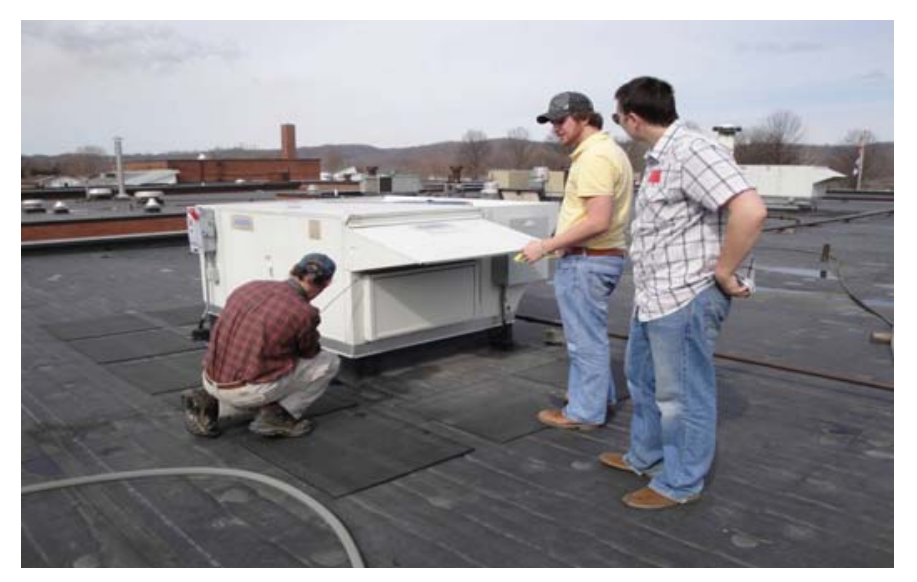

Figure 1.3 Measuring the Intake Air flow through the Dampers

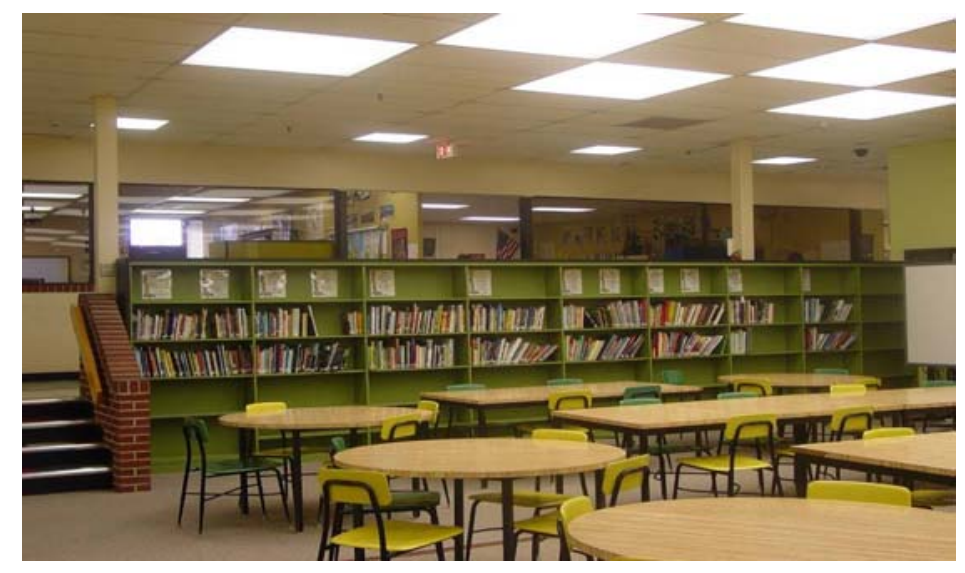

Figure 1.4 Measuring Lighting Levels in Pleasants County Middle School 


\section{Literature Review}

A study was made on the $\mathrm{K}-12$ schools that were certified by the leading Building Certifying system ENERGY STAR. A study by the American Society of Heating, Refrigeration and Air-conditioning Engineers (ASHRAE) 90.1 and Advanced Energy Design Guide (AEDG) for K-12 buildings was also done. Relative case studies were reviewed and a brief summary of the successful K-12 schools that saved energy using the recommendations given by ASHRAE 90.1, AEDG (K-12 schools) and also by West Virginia University (WVU) are provided. And a few other technical papers on expert systems and was also studied.

\subsection{ENERGY STAR}

ENERGY STAR is a government program administered by the U.S. Environmental Protection Agency (EPA) and the U.S. Department of Energy (DOE). Its goal is to protect the environment by identifying and promoting the use of energy efficient products and services [1].

At the first, ENERGY STAR rated and labeled computers for their energy usage. The label covers new homes, commercial and institutional buildings, residential heating and cooling equipment, major appliances, office equipment, lighting, and consumer electronics. For labeling commercial buildings, ENERGY STAR evaluates conformance to energy efficiency and indoor environmental standards, primarily ASHRAE (American Society of Heating, Refrigerating, and Air-Conditioning Engineers) and IES standards. It uses a statistical analysis data set, the DOE's Commercial Buildings Energy Consumption Survey (CBECS), to compare energy intensity of similar buildings across the country. 
EPA provides an innovative energy performance rating system which businesses have already used for more than 130,000 buildings across the country. If a building receives a score of 75 then it indicates that the building performs better than $75 \%$ of comparable buildings in the CBECS database.

ENERGY STAR's new building design guidance is a web-based initiative. It recommends actions at each stage of the design process, focusing on energy efficiency and integrated design. It begins with pre-design, and ends with the building earning the ENERGY STAR label.

The Energy Performance Target Finder is another valuable web-based tool. It allows the user to set an energy target, compare design energy and cost to that target throughout the design process, and measure the effectiveness of various energy design strategies.

For existing buildings, the web-based Portfolio Manager can be used to submit an application for an ENERGY STAR label. This tool allows benchmarking a building's energy performance (utility usage). Then, working with the program's building upgrade manual, helps achieve energy savings that will qualify the building for the label.

ENERGY STAR also has a Building Upgrade Manual [2] which gives a complete approach towards energy saving. First, there is management and planning advice section which consists of benchmarking the building's energy usage, investment analysis and financing. Second, is the staged approach to building upgrades which consists of Retrocommissioning, Lighting, Supplemental Load reductions, Air Distribution Systems and Heating and Cooling Systems. Apart from the staged approach for energy efficiency there are some unique challenges which 
are present for different building types and the manual consists of facilities like K-12 Schools, Supermarkets, Hotels and Motels and Retail Establishments.

\subsection{ASHRAE 90.1}

ASHRAE 90.1 standard was set to provide the buildings with a minimum requirement for the energy-efficient design with an exception for low rise residential buildings. With constant maintenance work done by American National Standards Institute (ANSI) and ASHRAE, the original standard 90 which was published in 1975 has revised editions published in 1980, 1989 and 1999. The recommendations of this standard are applicable to the envelope of the buildings, Heating, Ventilation and Air Conditioning (HVAC) systems, Service Water Heating, electric power distribution and metering provisions, electric motors and belt drives and lighting. The recommendations are not applicable to single-homes, manufactured houses, and equipment in the building which use energy for industrial, manufacturing and commercial processes [3]. The recommendations are available according to the climate zone in which the building is located. In figure [2.1], entire US is divided into 8 climatic zones with the major cities in each climate zone by US DOE and these zones are divided by county boundaries according to the temperature, they are also divided into sub-zones according to the humidity levels. A subzone represents Moist or humid conditions, B represents dry and C represents marine. The state of West Virginia (WV) consists of two climate zones 4a and 5a. 


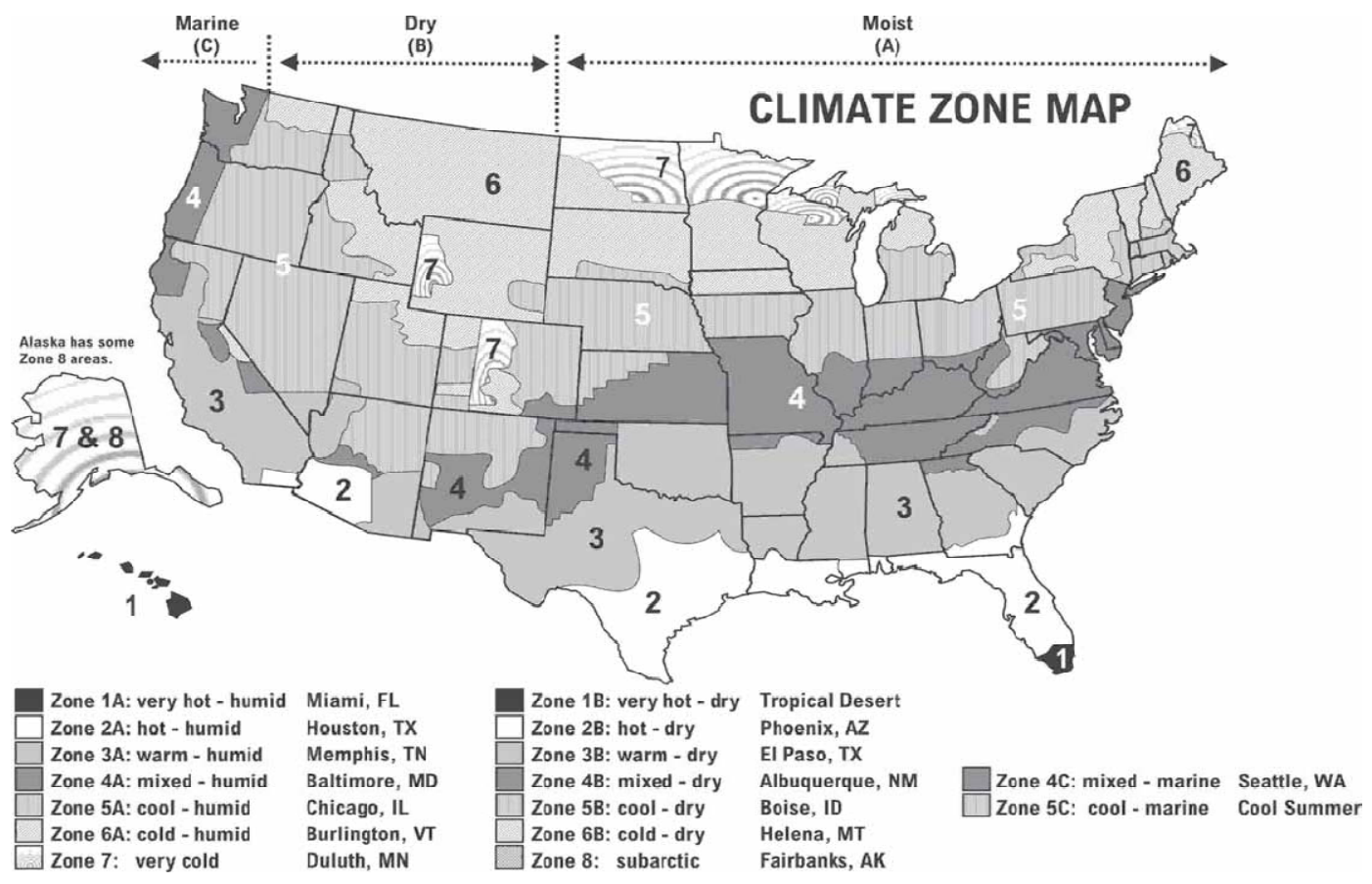

Figure 2.1, US Climate Zones [16]

According to these climate zones approximate energy consumption for heating, cooling, lighting, water systems, electrical devices and fans in the school are shown in figure [2.2] below. 


\section{ENERGY CONSUMPTION BY CLIMATE ZONE}

\begin{tabular}{|c|c|c|c|c|c|c|}
\hline $\begin{array}{c}\text { CLIMATE } \\
\text { ZONE }\end{array}$ & HEATING & COOLING & LIGHTING & $\begin{array}{c}\text { WATER } \\
\text { SYSTEMS }\end{array}$ & $\begin{array}{c}\text { ELECTRICAL } \\
\text { DEVICES }\end{array}$ & FANS \\
\hline $1 \mathrm{~A}$ & $0.5 \%$ & $27.6 \%$ & $27.4 \%$ & $1.0 \%$ & $19.7 \%$ & $23.8 \%$ \\
\hline $2 \mathrm{~A}$ & $4.6 \%$ & $19.8 \%$ & $28.9 \%$ & $1.4 \%$ & $20.8 \%$ & $24.4 \%$ \\
\hline $2 \mathrm{~B}$ & $2.0 \%$ & $22.5 \%$ & $28.1 \%$ & $1.2 \%$ & $20.2 \%$ & $26.1 \%$ \\
\hline $3 \mathrm{~A}$ & $7.2 \%$ & $14.3 \%$ & $30.9 \%$ & $1.7 \%$ & $22.2 \%$ & $23.7 \%$ \\
\hline $3 \mathrm{~B}$ & $2.9 \%$ & $15.0 \%$ & $32.6 \%$ & $1.7 \%$ & $23.5 \%$ & $24.3 \%$ \\
\hline $3 \mathrm{C}$ & $3.7 \%$ & $6.1 \%$ & $34.4 \%$ & $2.2 \%$ & $24.7 \%$ & $28.9 \%$ \\
\hline $4 \mathrm{~A}$ & $15.1 \%$ & $9.1 \%$ & $29.2 \%$ & $2.0 \%$ & $21.0 \%$ & $23.7 \%$ \\
\hline $4 \mathrm{~B}$ & $7.1 \%$ & $10.3 \%$ & $31.7 \%$ & $2.0 \%$ & $22.8 \%$ & $26.1 \%$ \\
\hline $4 \mathrm{C}$ & $10.6 \%$ & $3.3 \%$ & $34.2 \%$ & $2.4 \%$ & $24.5 \%$ & $25.1 \%$ \\
\hline $5 \mathrm{~A}$ & $23.8 \%$ & $6.5 \%$ & $26.1 \%$ & $1.9 \%$ & $18.8 \%$ & $23.0 \%$ \\
\hline $5 \mathrm{~B}$ & $15.6 \%$ & $6.3 \%$ & $29.3 \%$ & $2.1 \%$ & $21.0 \%$ & $25.7 \%$ \\
\hline $6 \mathrm{~A}$ & $32.8 \%$ & $3.9 \%$ & $23.8 \%$ & $1.9 \%$ & $17.1 \%$ & $20.5 \%$ \\
\hline $6 \mathrm{~B}$ & $26.5 \%$ & $3.7 \%$ & $26.1 \%$ & $2.1 \%$ & $18.7 \%$ & $23.0 \%$ \\
\hline $7 \mathrm{~A}$ & $39.6 \%$ & $2.0 \%$ & $21.1 \%$ & $1.9 \%$ & $15.2 \%$ & $20.2 \%$ \\
\hline $8 \mathrm{~A}$ & $58.7 \%$ & $0.6 \%$ & $15.4 \%$ & $1.5 \%$ & $11.1 \%$ & $12.7 \%$ \\
\hline & & & & & & \\
\hline
\end{tabular}

Figure 2.2, Energy Consumption of K-12 Schools by Climate Zone [16]

\subsection{Advanced Energy Design Guide for K-12 School Buildings (AEDG K-12)}

The AEDG K-12 guide is made for elementary, middle and high schools to achieve at least a $30 \%$ savings above those of the minimum requirements of ANSI/ASHRAE/IESNA 90.1-1999 Energy Standard for Buildings Except Low-Rise Residential Buildings, which is considered as a baseline. This Guide is not applicable for schools with Indoor-pools, wet labs and dirty labs and other places with high heat or pollution generation capacity. Recommendations given in this guide do not have all the components of ASHRAE 90.1 and the primary focus is on primary energy systems within the building [6]. These recommendations are provided for schools in 8 climatic zones in a detailed manner in the form of sections Envelope, Lighting, HVAC and Service Water Heating (SWH). 


\subsection{Case studies}

Since this study is on the schools which are in WV. According to ASHRAE 90.1-2007 these schools are in climatic zone $4 a$ and $5 a$. Therefore, the successful schools which used the recommendations of ENERGY STAR, AEDG K-12 and also the work done by West Virginia University on $\mathrm{K}-12$ schools are studied in this section.

\subsection{Schools Using ENERGY STAR Recommendations}

The case studies in this section are from Building Upgrade Manual [2] which gives details about schools which saved energy with energy efficient measures.

\subsubsection{Evansville-Vanderburgh School District}

The Evansville - Vanderburgh School District, Vanderburgh County, Indiana had school buildings that needed to install air conditioning units, with the help of an engineer with a firm named Veazey Parrott Durkin \& Shoulders and using the recommendations given by ENERGY STAR a two-pipe HVAC system was installed which had a lower installation cost than four-pipe versions. The schools also replaced their T12 lighting with T8s. By applying these recommendations the district wide schools could save around 18.2 percent per year [2].

\subsubsection{Daniel Boone High School}

The Daniel Boone High School, Washington County, Tennessee chose to install a geothermal heating system which was more expensive than a two-pipe system and was also the next best option. But that additional $\$ 197,000$ on the geothermal system saved $\$ 62,000$ 
during the first year. And an additional advantage of the geothermal system is it also has a flexibility to vary temperature set-points for individual zones by using direct digital controls.

\subsection{Schools Using AEDG (K-12) Recommendations and LEED certified}

\subsubsection{Third Creek Elementary School}

Third Creek Elementary School, Statesville, North Carolina is a $92,000 \mathrm{ft}^{2}$ building completed in July 2002 at a cost of $\$ 8.7$ million. The building was merged into one building from two old schools and was certified with a LEED v2.0 Gold Certification on completion of the construction. With all the design recommendations applied to the school reduced energy costs of $25 \%$ annually was shown by an energy model and after three years of operation, i.e., in 2005 the number was increased to $33 \%$ annually [6].

\subsection{Schools Using WVU Recommendations}

Suncrest Primary School, Monongalia County, WV could save around $\$ 6,671$ yearly by installing R-30 roof insulation for a pitched roof building with a payback period of just 9 months and also changing of single paned windows to double paned windows has saved $\$ 1880.00$ annually. In Suncrest Middle School, in Morgantown WV has saved $69,120 \mathrm{kWh}$ annually by changing T-12 40 watts bulbs with magnetic ballast to T-8 32 watts bulbs with electronic ballast. Pleasants County Middle School and Belmont Elementary in Pleasants County WV school have saved $\$ 18,000$ by insulating the roof with $R-19$ insulation, removing the excess T-8 bulbs and reducing the excess air brought in by the HVAC units. Slanesville Elementary School in Hampshire County WV used a staged make-up air unit which could supply $3000 \mathrm{cfm}$ of 
air for the kitchen and would heat the air only when needed, the unit had a payback period of just 1.5 years.

\subsection{Expert Systems}

Expert systems are problem solving tools which use a human expertise knowledge base for aiding in decision making process for users who are skeptic about making an appropriate decision when needed.

There are three major methods of operation for an expert system [26]. They are certainty factors, chaining and inference rules. In the chaining method there are two methods, forward chaining and backward chaining. Forward chaining can be defined as a method which starts with an available data and uses rules to extract data, from going through certain rules until one is found to be true. If there are several possible solutions to the same problem then this method is best useful. Backward chaining can be defined as a method which starts with a rule and then finds data to prove factors in that rule that would reach a solution. Different types of systems are used in organization levels for performing specific functions and a few of such are strategic-level systems, management-level systems, knowledge-level systems and operational-level systems. Strategic level systems are known to be supporting the executive personnel, management level are used by the managerial personnel for decision making, information management and as support tools, knowledge level are used for office work and operational level systems are used in processing types [7]. The figure [2.3] shows typical expert system components. 


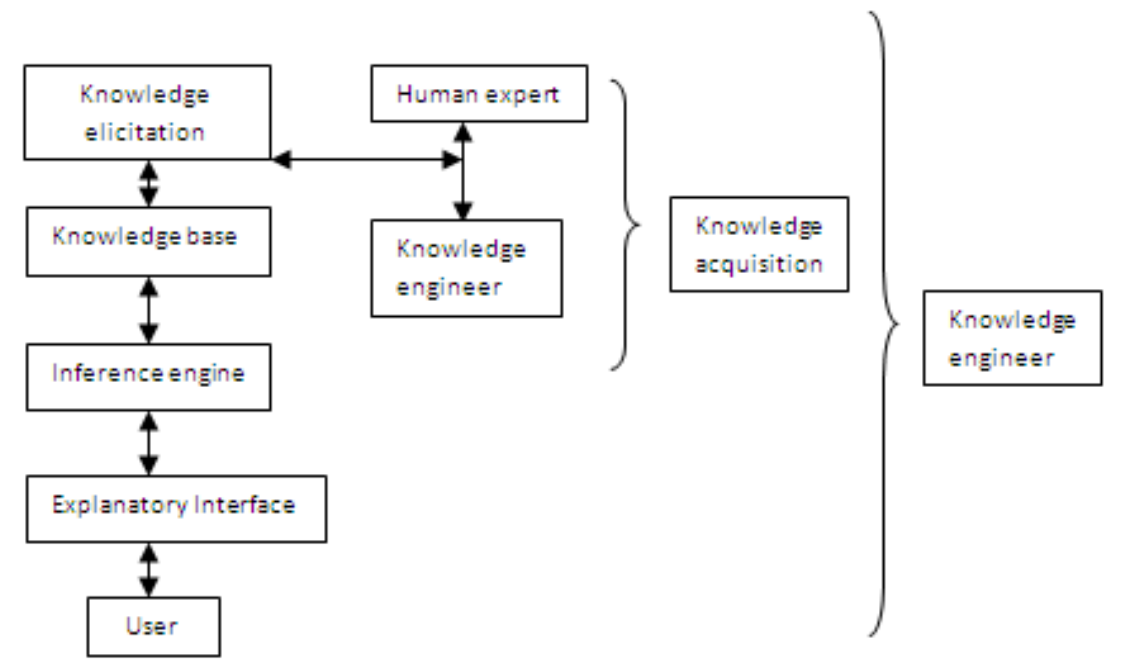

Figure 2.3 Expert system components [8]

Expert systems are generally classified in two types, based on knowledge type, one is, declarative or content type which can be defined as the knowledge required towards the nature of a task and second is, procedural or process type which can be defined as the knowledge required to perform a task efficiently in different ways [8].

\subsection{Currently Available Expert systems}

Presently, there are a number of expert systems which are used in various applications. An expert system (ENERGEX) developed by West Virginia University's (WVU's) Industrial Engineering Department is used to assist engineers in the industries to develop energy conservation opportunities (ECOs) in industrial plants [7]. ENERGEX provides recommendations in lighting, boilers, selection of motors, belt-driven systems analysis, 
insulation and operations of air compressors. ENERGEX is a PC-based system with the knowledge of an expert auditor built into a software package. Upon answering some queries about the plant, the software displays the type of ECO's and the user can select any of them, upon selecting the one ECO there are a series of questions which show up regarding to the ECO. Once the queries are answered the program provides the user with cost and energy savings, implementation costs and payback period. The whole package uses Backward Chaining Method for arriving at a conclusion. Another expert system named 'Wood Energy Expert System' developed by WVU's Mechanical and Aerospace Engineering Department and Appalachian Hardwood Center is used to determine if a wood fueled boiler is economical and feasible for the specific application being examined [9]. Same as ENERGEX expert system, this system also requires the user to enter answers to a series of questions which are used to design a wood fueled boiler system. On the other hand this system uses Forward Chaining to arrive at a result. As there are various recommendations possible for the wood fueled boiler system so the forward chaining technique is used.

\subsection{Energy Saving Works using different standards}

The Texas A\&M University has developed a web-based emissions reduction calculator for code-compliant commercial construction [10] and the objective of this software is to reduce oxides of nitrogen $\left(\mathrm{NO}_{\mathrm{x}}\right)$ emissions by implementing ASHRAE 90.1-1999 standards. Different simulation models of office and retail end-use buildings were created for a general commercial configuration, to quantify the reduction of $\mathrm{NO}_{\mathrm{x}}$ emissions in new constructions. As there are different types of constructions and HVAC equipments present in commercial sectors so the simulation models were modified accordingly. DOE 2.1e simulation program was used to 
create simulation models and then link the models to a web-based graphic user interface and US EPA's eGRID to convert the energy savings to $\mathrm{NO}_{\mathrm{x}}$ emissions reduction. Using the [11] the Texas Engineering Experiment station (TEES) has developed a web-based, Code-Compliant ASHRAE 90.1999 commercial simulation for Texas. The software is attached to DOE-2 software with database platforms running in a cluster of servers and this software is used to check code compliance of new commercial construction for specific building types by commercial builders in Texas. The DOE-2 is a freeware building energy analysis program that is used to predict the energy use and cost for all types of buildings. DOE-2 uses a description of the building layout, constructions, operating schedules, conditioning systems (lighting, HVAC, etc.) and utility rates provided by the user, along with weather data, to perform an hourly simulation of the building and to estimate utility bills [37]. The system provides the user with comparison of total annual energy use between ASHRAE 90.1-1989 and 90.1-1999. The models developed are used to determine the annual and peak day energy savings attained by constructing code-complaint buildings for office, retail buildings, schools and hotels. The resultant savings are processed in EPA's eGrid program to calculate annual and peak $\mathrm{NO}_{\mathrm{x}}$ reductions at the power plants that provided the electricity to the building.

The analysis of the Energy saving potential in K-5 schools [12] in Hot and Humid climates was done by TEES on an existing K-5 school in Central Texas. First, the hourly building energy simulation was performed in DOE-2 program and calibrated with the actual building energy use. After that, the calibrated building energy use is modified to make the energy use compliant with ASHRAE 90.1-1999 and treat it as a base case. Then AEDG K-12 school energy saving recommendation for climate zone 2 is used and applied on the base-case so as to find the 
energy saving potentials. By using the AEDG recommendations the school could save $\$ 25,561$ annually which is $27.1 \%$ less than the base-case. After applying AEDG to the [12] another set of high performance measures and renewable energy systems was applied on a baseline school which is compliant to ASHRAE 90.1-1999, which gave a savings of $38.6 \%$ and including the solar thermal and photovoltaic systems the school could save $68.2 \%$ [23].

A survey was done on high performing schools using US DOE Energy Efficiency and Renewable Energy (EERE) database, which gives the information about energy efficiency measures for school buildings and the case studies of several existing high performance schools. According to the EERE database the Energy use intensity (EUI) for high performance schools is about 23 to 60 ( $\mathrm{kBtu} / \mathrm{sq} . \mathrm{ft}$.), which is on an average of 51 to $62 \%$ less than national average and also is 20 to $40 \%$ lower than the schools compliant with ASHRAE 90.1-1999 [21]. The report [24] shows the analysis of the potential energy savings of four base-case school models that are compliant with ASHRAE 90.1 for three climate zones. A total of 18 measures were considered and applied, which demonstrated $20.2 \%$ to $24.6 \%$ of combined savings more than 1999 base case in AEDG K-12 schools.

The North Carolina Department of Public Instruction has developed Energy Guidelines for K-12 schools which were prepared to assist the construction team to make decisions such that there is less energy used by the facilities. The 2009 NC state building code has set ASHRAE 90.1-2004 as the building energy usage standard and any building designed should operate with at least 30\% lesser energy usage than the base building descried in ASHRAE 90.1 standard [13]. These guidelines start with building energy performance analysis and consist of energy saving 
options in architecture, plumbing, controls, hvac and lighting and power systems. In the end there are also commissioning, operation \& maintenance recommendations also. A simplified simulation tool for high performance K-5 schools in hot and humid climates was developed to automatically generate building shape and to get a calibrated simulation of a case study K-5 school [22]. The differences between simulated and measured values have a $19 \%$ of Root mean square error and $1.4 \%$ of Mean bias error. 


\section{School Expert System Components}

Building Energy savings can be of various types. After a review of various WV school reports and energy saving recommendations given by ASHRAE 90.1, ENERGY STAR and AEDG K12 schools, a format was chosen and saving types were divided into 5 major types

- Building Envelope Savings

- Lighting Savings

- HVAC Savings

- Service Water Heating Savings

- Miscellaneous Savings

* Building Envelope Savings:

Building Envelope can be defined as the exterior plus the semi-exterior portions of a building. Exterior can be defined as the portions of a building that separate conditioned space from the exterior and semi-exterior can be defined as the portions of a building that separate conditioned with an unconditioned space. In this savings there were four types of savings taken into account Roof Insulation, Wall Insulation, Window Caulking and Window single to double paned. Roof and Wall Insulation are about changing the present insulation R-value to a better R-value. Window caulking is about caulking a window periphery with caulking material. And the last one is the changing of single paned window to a double paned window. Door WeatherStripping is sealing the door with a thin strip of compressible stripe to stop interior air from escaping. The flow chart is shown below. 


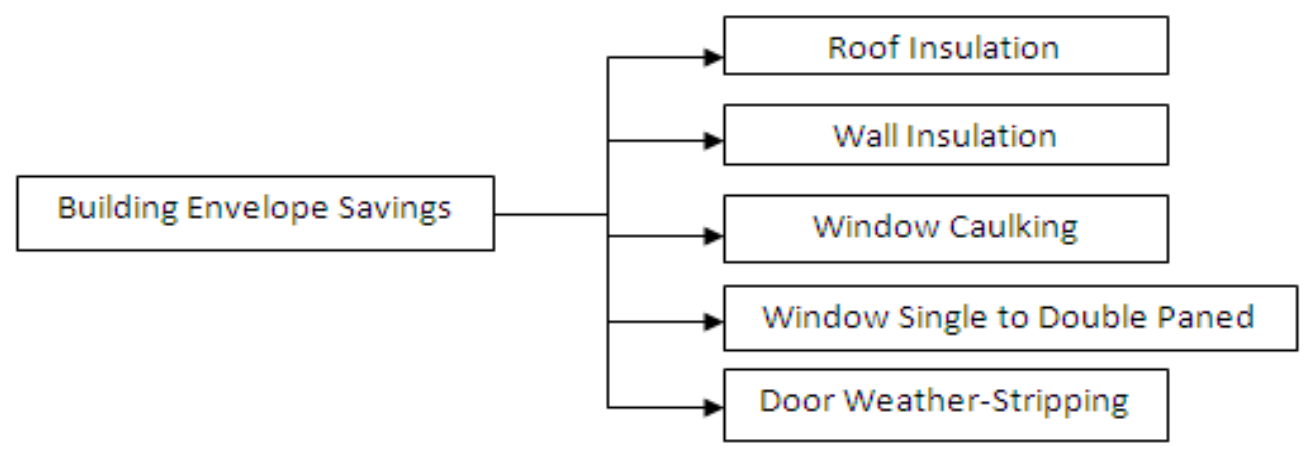

Figure 3.1 Building Envelope saving options

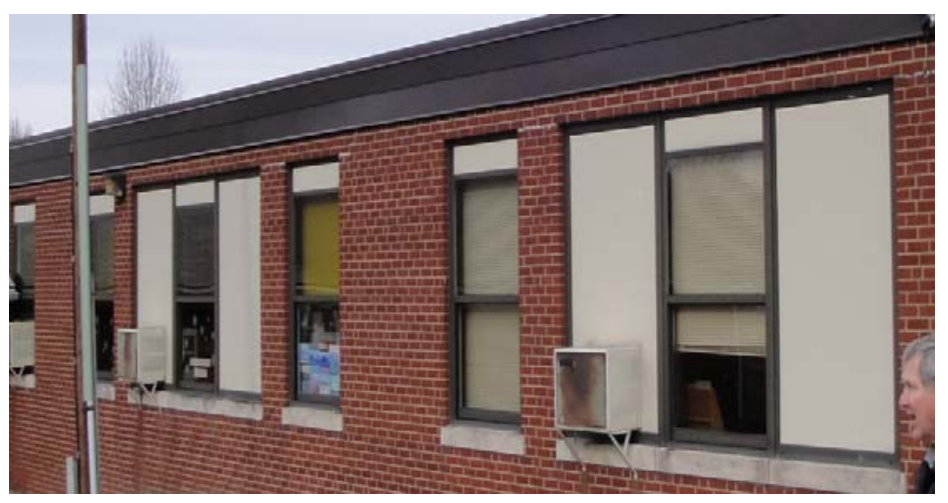

Figure 3.2 Checking the Belmont Elementary School Windows during Audit

Lighting Savings:

Lighting savings can be obtained from changing the low efficient lighting systems with high efficient lighting systems. The saving options are mainly divided into three options, Fluorescent Bulbs, High Intensity Discharge and Lighting levels. The T12 stands for the diameter of a bulb in eights of an inch i.e., 12/8 equals 1.5 inches and in the same way T8 stands for $8 / 8$ equals 1inch. The options in Fluorescent section are T12 96 Watts magnetic ballast to T8 59 Watts electronic ballast, T12 40 Watts magnetic ballast to T8 32 Watts electronic ballast, T12 40 Watts magnetic ballast to T8 28 Watts electronic ballast, T12 40 Watts magnetic ballast to T8 25 
Watts electronic ballast, T8 32 Watts to T8 28 Watts, T8 32 Watts to T8 25 Watts. In the High Intensity Discharge section Metal Halide 400 Watts to 360 Watts Magnetic Ballast, Metal Halide 400 Watts to 360 Watts Electronic Ballast and in lighting levels section the option is lighting level Requirement.

The last option is the maintaining of lighting levels in different areas of the school and if any activity area has higher lighting levels it is recommended to remove the excess bulbs or add extra bulbs if needed. Before choosing this option a lighting level calculation method was taken into account. In this method, the Room cavity Ratio (RCR) was calculated, which is a measure of room proportion determined by length, width and height of the room in feet. After calculating RCR the lighting levels of the room in Foot-candles (fc) was calculated. In this calculation the Light Lumens (LL), Co-efficient of Utilization (CU) and Light Loss Factor (LLF) are used. But the LL, CU and LLF for each bulb is different depend on manufacturer, and are time degradable, and there are other factors which come into consideration. As the information needed for the calculation is large and varied, the results are not consistent for an expert system, so this method of calculating lighting levels was not considered.

The LED lighting is not included in the options because LED's do not emit heat energy and if they are installed the heating loads are increased in the room and the other reason is the cost of installing the LED's is very high. The skylights option was applied on different schools in climate zones 4a and 5a using DOE-2's eQuest software and it was found that the schools instead of saving energy are wasting energy and the reason being the solar heat gain and infiltration losses. Figure [3.2] shows Brandywine Elementary school in Pendleton County WV 
with skylights ON. The reasons for not included Daylighting option is, it requires an in depth study about Daylighting in each room, if the skylights are not installed properly the infiltration losses are high and if there are ducts present above the ceilings, the duct system should be redesigned for bringing in the daylight. The flow chart is shown below in figure [3.3].

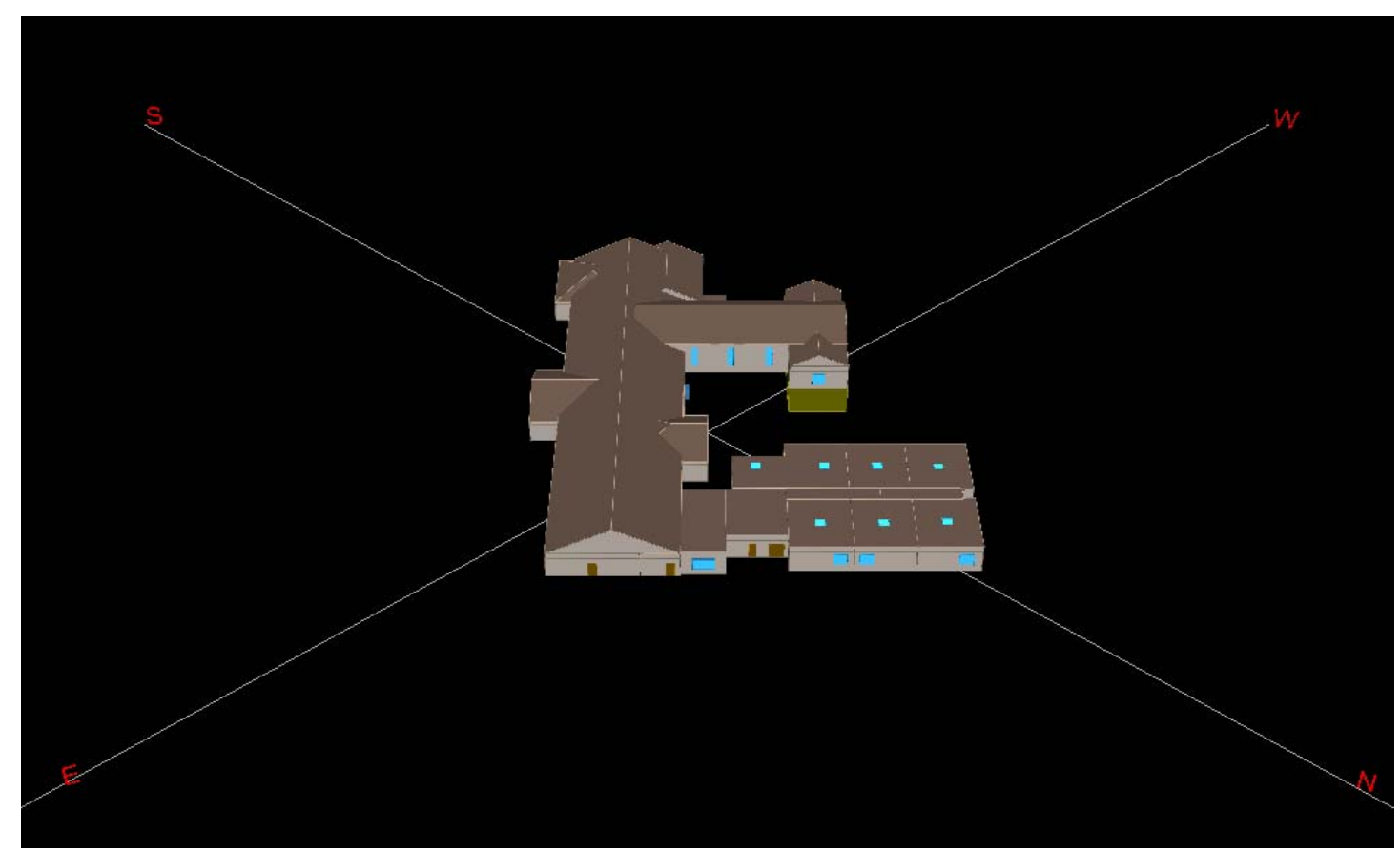

Figure 3.3 Brandywine Elementary School with Skylights 


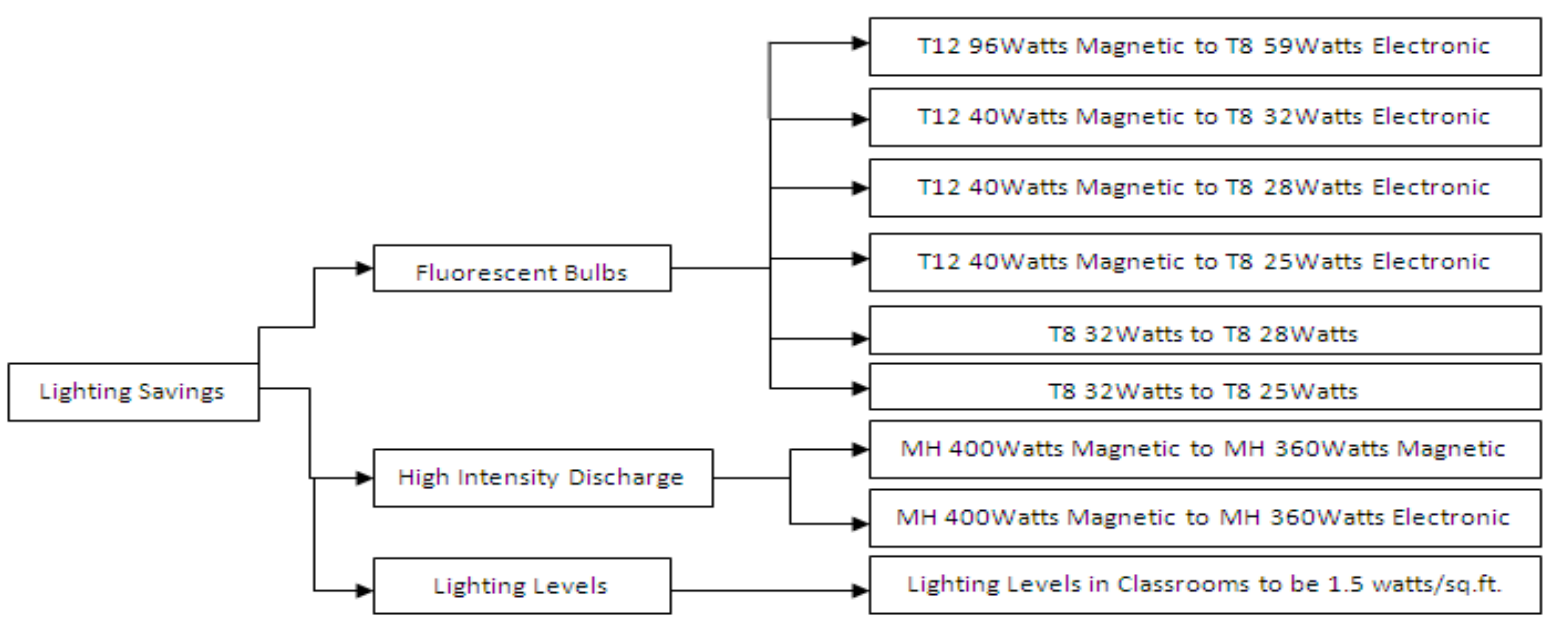

Figure 3.4 Lighting Savings Options

HVAC Savings:

HVAC savings are about the saving options which can be obtained by changing, upgrading or making new additions to Heating, Ventilation and Air Conditioning units. The options in this section are

- 'Duct Insulation' - is the insulating of the ducts carrying the air from HVAC units with better R-Value.

- 'Cooling SEER'- is the improving of Seasonal Energy Efficiency Ratio of the AC units. 'Amount of Ventilation air needed' - is the saving option which gives information about how much outside air is needed each minute by the school and also about how much energy can be saved by limiting the air needed.

- 'Shut-off Electric Reheat System' - is about shutting off the electric reheat system in summer time so as to stop energy usage for heating. 
- 'Economizer'- air economizer is used to bring in air without cooling it when the outside is below certain temperature.

- 'Staged Make-up Air Unit' - is an electric staged make-up air unit used in kitchen, which can be installed instead of a normal make-up air unit.

- 'Setback Controls' - are used to decrease temperature during heating season unoccupied hours so as to save energy.

- 'HVAC Maintenance' is an option where a set of advices and benefits are provided to the user by cleaning and maintaining the different HVAC systems.

The Variable Speed Drive Fans are good option but there are reasons due to which this option is not included. Most of the schools have Packed Single Zone units and the VSD is not required for such units, high initial costs, if the average speed requirement is near the rated speed level of the motor the energy savings are generally low, requires regular maintenance and special knowledge personnel for trouble shooting. Another option which is not included is the use of Thermal Wheel and the reasons for not including it are high initial cost, since two air streams are adjacent to each other in the unit, constant maintenance is required, the fill-medium should be maintained. If not repaired properly, air cross-contamination is possible. The flow chart is shown below. 


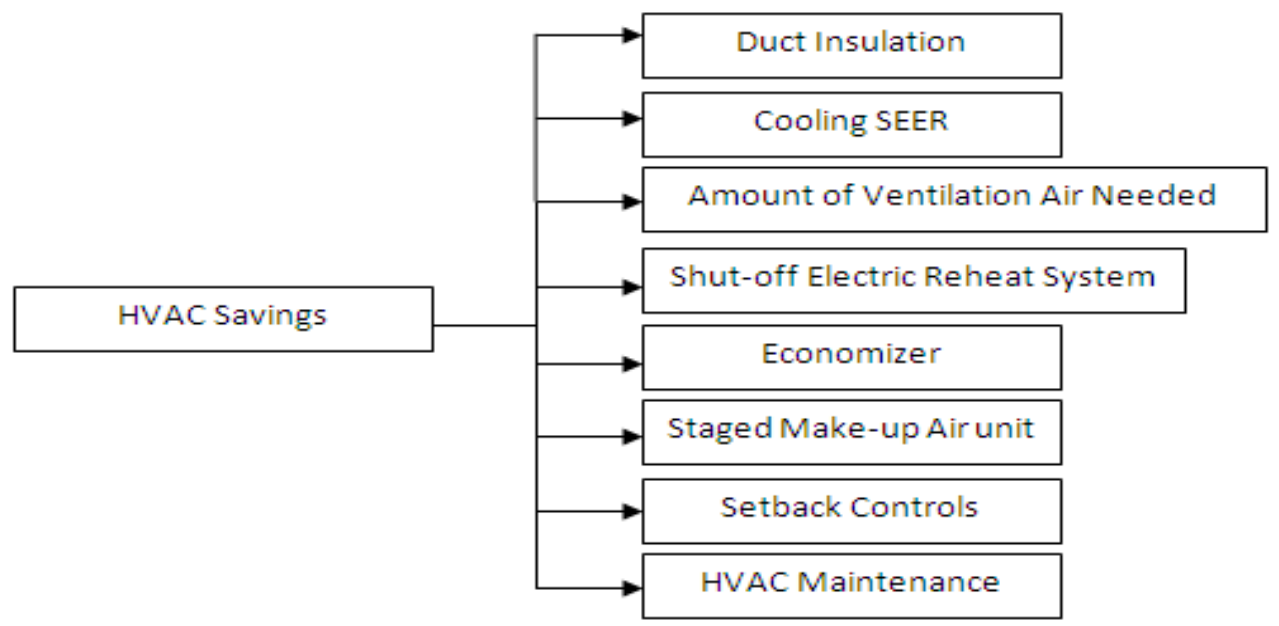

Figure 3.5 HVAC Savings Options

Service Water Heating Savings:

In this section the savings from service water heating can be obtained by choosing the seven options listed below. First option is 'Excess Oxygen Sensor', which is using a probe consisting of an oxygen sensor, which gives the user the information about the amount of excess oxygen used in a boiler for burning the fuel by reducing the amount of oxygen, energy is saved. Second option is 'Heater Insulation' which is insulating the water heater with better rvalue. Third option is 'Instantaneous Heater' which is replacing the conventional storage water heater with an instantaneous water heater. Fourth option is 'Water Heater efficiency' improving, by installing a new water heater with better efficiency less fuel is used for heating water. Fifth option is 'Boiler maintenance', which is the cleaning of the scales formed inside the boiler walls; scales formed inside the boiler acts as an insulator certain percentage of heat required to boil the water, because of which more fuel is required to boil the water. Sixth 
option is 'Water Temperature' which is heating the water more than the required temperature for domestic use; most of the schools heat the water to more than $120^{\circ} \mathrm{F}$ if they bring it down to $120^{\circ} \mathrm{F}$ they could save substantial amount of money. Seventh option is 'Pipe Insulation' which is insulating the water pipes serving the hot water coils to the HVAC units and other domestic uses. The flow chart is shown in figure [3.5].

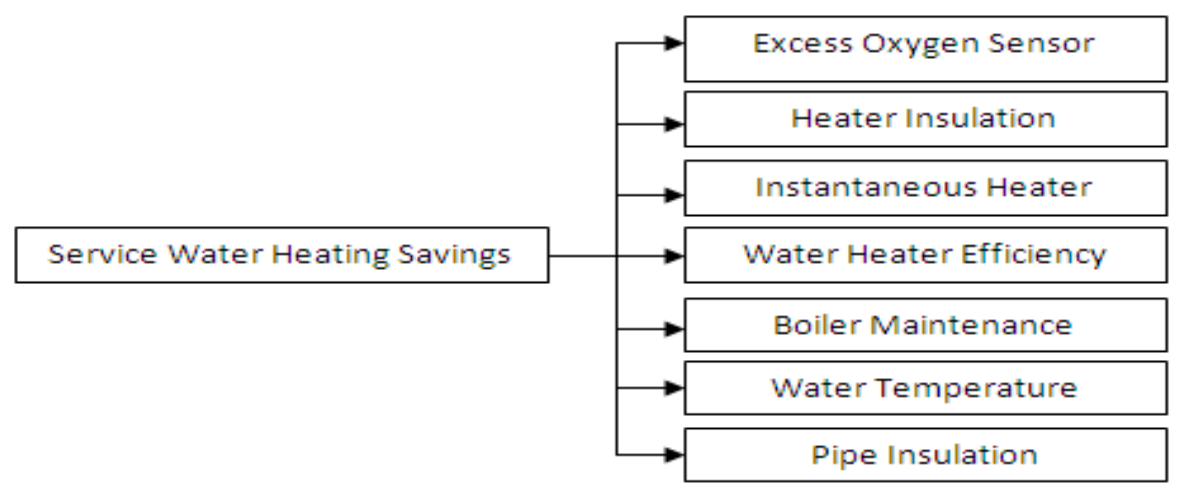

Figure 3.6 Service Water Heater Savings Options

Miscellaneous Savings:

Miscellaneous savings can be classified as the extra category savings which have gone unnoticed or widely ignored. There are four options which were found useful. They are Computer Low Power Mode, Shower Heads, Faucet (aerators) and Pool covers.

- 'Computer Low Power Mode' is an ENERGY STAR EZ GPO or EZ Wizard tool which can be installed in a computer for free and puts the computer in a hyper sleep mode.

- 'Shower Heads' is the changing of shower heads to a lower more efficient flow rate shower heads. 
- 'Faucets (aerators)' is also same as the shower heads.

- 'Pool Covers' is putting a cover on a swimming pool so as to save water and also energy.

- 'Faucet Leaks' is fixing the faucets so that the leakage of water is minimized. The flow chart for the above saving types is shown below.

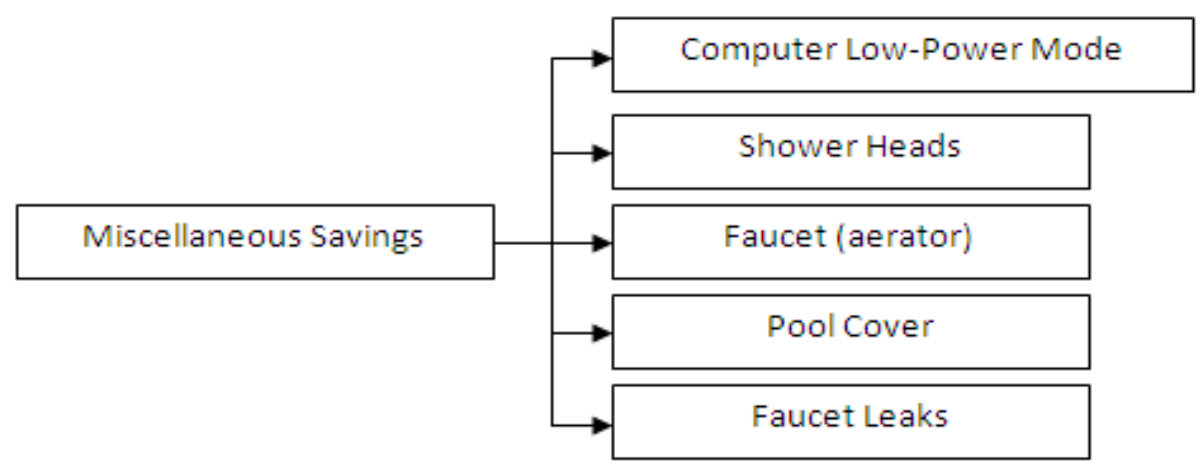

Figure 3.7 Miscellaneous Savings Options

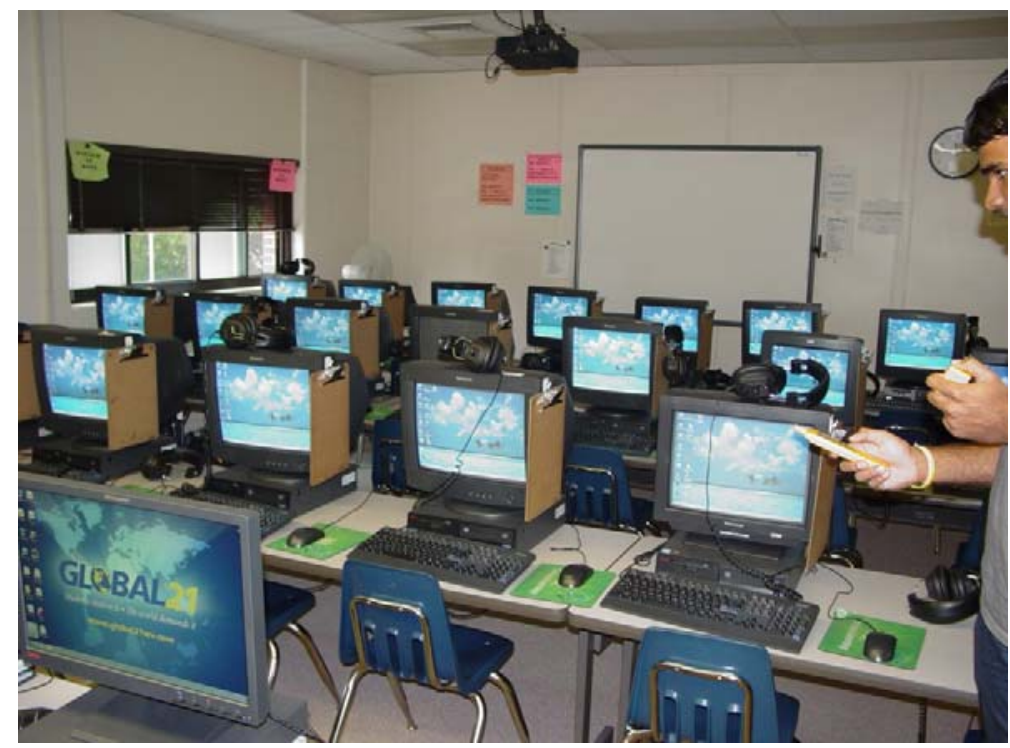

Figure 3.8 Computer Room in Bethlehem Elementary School Ohio County, WV 


\section{Methodology used}

The system developed in this case uses Forward Chaining Method to arrive at a result. The system acquires data by user inputs in the form of answers to series of questions, and then uses these data to evaluate a series of rules entered in the program in the form of 'If' and 'Else if' statements and also some switch cases. This chaining method was used for this application because there are various recommendations that could be made for the savings types. When one of the rules is true which is confirmed by the user input data, then based on that rule the program uses information to set default values and also determine what equations will be applied for the calculations.

The system is designed such that it can be used by the users who are familiar with the building operation and maintenance. This expert system has a several energy saving recommendations to choose from and upon selecting the recommendation and entering the answers the expert system gives a result. To develop such a system, specific data needs to be compiled and formulae need to be entered into the system. The expert system shows a result when the information to a problem is gathered usually through a series of questions, and then coupling the information with a series of rules. When the data is gathered and executed properly the expert system can take the place of an expert and give appropriate results.

\subsection{MATLAB}

The MATLAB 7.9.0 (R2009b) programming language stands for Matrix Laboratory was developed by Mathworks and released in 1984. MATLAB is available to users with a license under an exclusive legal right of the copyright holder. MATLAB is used for matrix manipulations, 
functions and data plotting, algorithm implementation, creating user interfaces and interfacing with programs written in programming languages like $\mathrm{C}, \mathrm{C}++$, Java and FORTRAN. Programs written in MATLAB are also operable on Windows and Linux [27].

MATLAB is an object oriented programming language and has an array structure in which each element of the array has the same field names. MATLAB code can be executed by typing it in the command window. With a number of tools it is very helpful for a user to create a program with improved performance and also improved graphics.

\subsection{MATLAB Graphical User Interface (GUI)}

Graphical User Interface can be defined as a human-computer interface which uses icons, windows, pushbuttons and menus, which can be controlled or accept inputs by a mouse and to an extent with keyboard also. Graphical user interface has two types, one object oriented user interfaces and the other application oriented interfaces. An object oriented user interface is about controlling entities like functions, variables, values and data structures using a programming language [28]. MATLAB GUI can be initiated by the typing guide in the command window and selecting blank GUI in the menu. The Guide start-up screen is show in the figure [4.1]. 


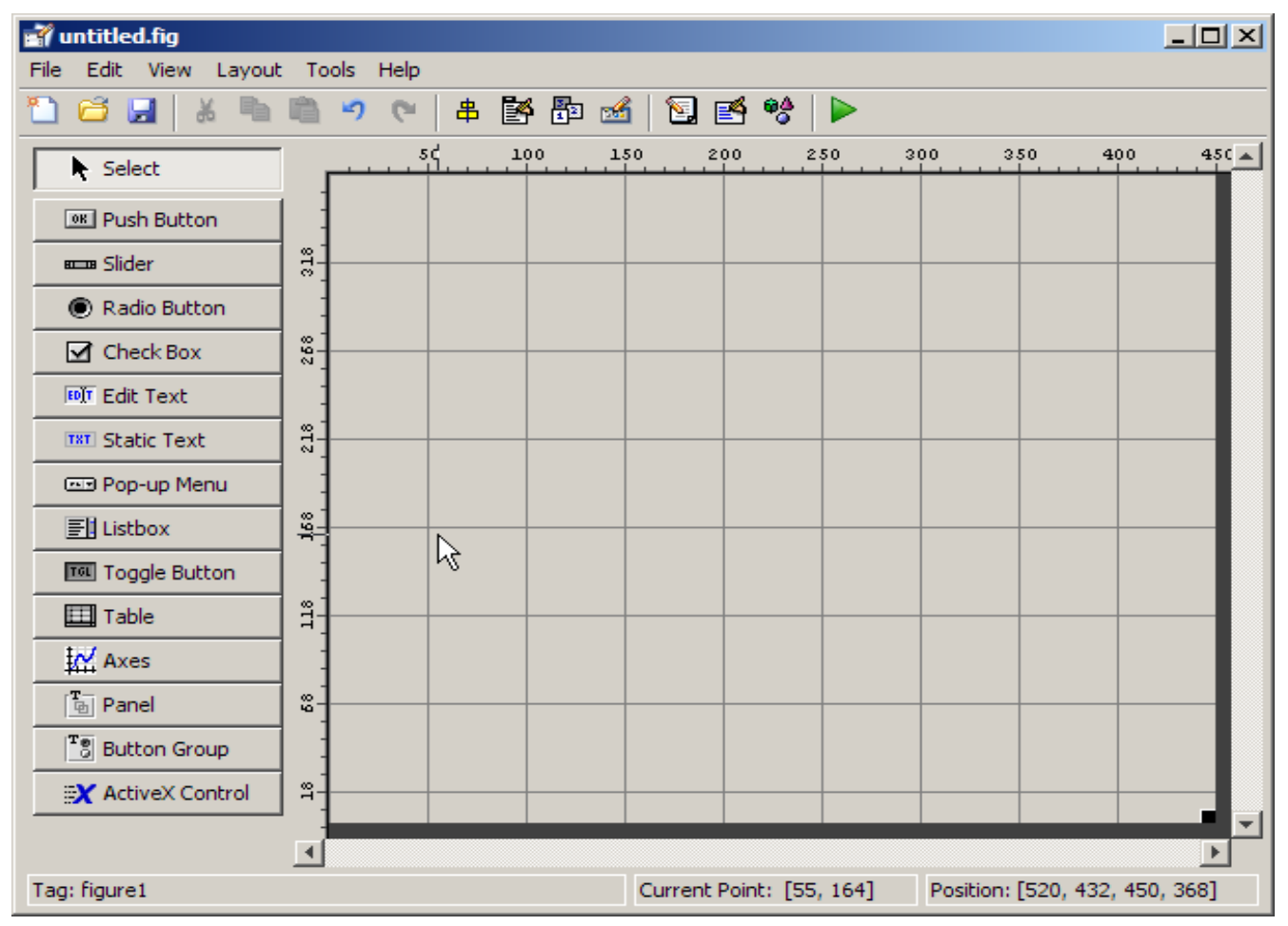

Figure 4.1 MATLAB GUI Introduction Screen

The MATLAB GUI consists of several options as shown on the left hand side of the figure shown above to create an interface. The user can select any of the components necessary to create a GUI and after saving this GUI there is program which is automatically generated. After the generated program appears there can be a custom code which the user can write in the generated program so that the program runs as the user desires.

MATLAB GUI was selected for this project as it is easy to use and can be operated on various operating systems and it can be converted into a web-based program. The important thing was that the language used was compatible with the webpage format and various other operating systems, so that a webpage version will be available for the user. 
MATLAB Builder NE is a tool which can create a .NET or COM components from MATLAB programs, GUI's and graphics. These components can be deployed into computers which do not have a MATLAB installed by integrating them into .NET, COM and web applications. This whole process is done using a MATLAB compiler in which the MATLAB programs are encrypted and are generated into .NET and COM components [28]. By doing the above mentioned process the user has no need of installing any type of other components and can directly use a webpage. 


\section{GUI Development:}

The GUI developed for this project uses selections and user inputs to determine if the recommendation is economically feasible option for school board to go forward with. The GUI discussed in this thesis will determine the energy savings, money savings, and installation cost and payback period for each and every recommendation the user selects and inputs required data to the questions in each recommendation. Several issues need to be addressed and considered about the saving types and the calculations.

\subsection{Input and Output}

In the opening screen of the expert system there is information regarding the WV counties and the climate zones in which the WV counties lie in. Upon starting the GUI, there is a saving type's panel box on the top left corner of the screen and has Building Envelope savings, Lighting savings, HVAC savings, Service Water Heating and Miscellaneous savings options as buttons. Upon selecting each saving type there is information box in middle of the screen which gives detailed information regarding each saving type and the saving choices in each and their limitations given by ASHRAE 90.1, ENERGY STAR or AEDG for K-12 schools. Below the saving type's panel box there is a list box which consists of the saving choices. As the user clicks any of the choices, the input screen appears where there are different inputs requirements which the user needs to enter and select. Upon entering all the data and required selections made by the user there is a savings button which the user needs to click on, upon clicking, the analysis will be performed and energy savings, money savings, installation cost and pay period are displayed as the outputs to the user. If the user wants to go back to the main menu then there is button 
in the bottom right corner of each input pop-up screen. The output for Energy Saved can change accordingly, as per the user selection of fuel type in cubic foot/yr for natural gas, gallons/year for Fuel oil and Propane and $\mathrm{KWh} / \mathrm{yr}$ for electric heating. According the fuel selected the payback period changes.

\subsection{Questions, Selections and Errors}

There are a several types of questions which appear upon selecting different energy saving choices, by answering those questions the parameter information needed for the formulae are fulfilled to run the savings calculations. For example, if a user selects the Roof Insulation energy saving choice the question which appear are

1. Selecting Type of Roof (Flat or Pitched Roof)

2. Selecting Roof with Material Type

3. Enter the present Roof Insulation R-Value (h.ft ${ }^{2}$.F/Btu)

4. Enter the changed Roof Insulation R-Value (h. $\mathrm{ft}^{2}$.F/Btu)

5. Enter the HVAC unit Efficiency (\%)

6. Enter the Roof Area $\left(\mathrm{ft}^{2}\right)$

7. Selecting the climate Zone $4 a$ or $5 a$

8. Selecting Fuel type used in HVAC units Natural gas, Propane, Fuel Oil \# 2, Electric.

When the user selects any roof with different material type then a default value appears in the "Present Roof Insulation R-Value" section and if the user knows the R-value of the roof then the user can enter the value manually. If the user enters a number less than 1 then there is an error dialog which appears as "Enter a number greater than 1", if the user enters a special character 
then the error dialog appears as "Enter only numbers". The same information can be carried to other questions also. Upon the selection of climate zone and fuel type there are certain default values which are selected by the program for the values of parameters needed for savings calculations. The selection of climate zones and fuel type if the user selects a climate zone and a fuel type the program is written in such a way that only one button is on and the others are off. When the electric heating is selected as fuel type then the HVAC unit efficiency is set as $100 \%$ and there is a warning dialog which appears as "Electric Heaters are $100 \%$ efficient". There is another question which appears upon selecting different fuel types, "Do you know how much you pay for a unit of fuel?" which changes appropriately as per the fuel selected, there are two buttons "Yes "or "No" which also appear. Upon selecting "Yes" there is an extra question which appears as "Enter the amount (\$)" and a box to enter the amount, and on selecting "No" there is default fuel cost which appears for each fuel.

\subsection{Default Information}

If the user does not know the answer to one of the questions asked or if a user selects different options in different types of questions as data input, then the program will use an educated estimation of the unknown value by using information from database.

The user selects climate zones $4 a$ or $5 a$ for the calculations to run, if a user selects climate zone 4a then the default values which are used are Heating Degree Days (HDD) as 4987 in Roof, wall, Duct insulation and Single to double paned windows options ; Cooling Degree days (CDD) as 1288 in Seasonal Energy Efficiency Ratio (SEER) ; Cooling Load (CLoad) in Economizer option as 1880.5 Btu.hr/lb-air; Heating Load (HLoad) as 8050 Btu.hr/lb-air in Staged 
Make-up air unit; Velocity of air (V) in Window caulking option as $16 \mathrm{mph}$ and if the user selects climate zone 5a then the default values are Heating Degree Days (HDD) as 5522, Cooling Degree days (CDD) as 985, Cooling Load (CLoad) as 2925.4 Btu.hr/lb-air, Heating Load (HLoad) as 8700 Btu.hr/lb-air and Velocity of air (V) as $18 \mathrm{mph}$. If the user selects any of the four fuel types then there is a default heating value for each type of fuel Natural Gas is $1050 \mathrm{Btu} / \mathrm{cu}$. $\mathrm{ft}$, Propane is $90000 \mathrm{Btu} /$ Gallon, Fuel oil (\# 2) is $140000 \mathrm{Btu} /$ Gallon and Electric is $3413 \mathrm{Btu} / \mathrm{KWh}$. If the user does not know how much he pays per unit of fuel then upon selection of a No option, then there is a default fuel cost for each fuel type which is shown on the screen for the user $\$ 10 / \mathrm{MCF}, \$ 2.65 /$ Gallon, $\$ 2.6 /$ Gallon and $\$ 0.07 / \mathrm{KWh}$. There are also some more default values the user can obtain if he doesn't know by clicking the pushbuttons for certain questions like number of hours the lights are ON per year.

\section{Calculations}

The entire questionnaire present in the expert system which the user has to answer for each saving option are installed taking into consideration that every question has an answer in the school drawings and other information would be present with maintenance personnel. To determine the energy and money savings, installation cost and payback period there a series of calculations which were performed. The input questions in the program and the formulae used are given below for each section. The Heating Degree Days (HDD), Cooling Degree Days (CDD) were calculated according to the climate Zones, for Climate Zone 4a the average HDD and CDD values of Mercer, Kanawha and Tyler counties was calculated and for Zone $5 a$ the averages of Summers, Lewis and Hancock counties was calculated [14]. The 
average of these counties was chosen according to the latitude of each county from south to north in each climate zone. The Energy Saved results are obtained in MCF, Gallons and kWh.

\section{- Building Envelope Savings}

1. Roof Insulation: In the Roof Insulation section the user has to enter the present roof Rvalue, the changed R-Value, efficiency of HVAC system, Roof area, select climate Zone and Fuel type. There are two different types of roof construction in most schools namely Flat and Pitched roofs. The both roof types have several options, upon selection the value in present R-value box changes accordingly. If the user knows how much he pays for the fuel then he can enter the amount he pays per MCF or gallon or KWh of the type of fuel he selects. If not then their default fuel cost which are displayed.

$$
\mathrm{ES}=\frac{\mathrm{RA} * \mathrm{HDD} * 24 *(\mathrm{U} 1-\mathrm{U} 2)}{\eta * \mathrm{HV}}[6.1]
$$

Where, ES = Energy Saved, MCF/yr, Gallons/yr, kWh/yr

$$
\begin{aligned}
& \mathrm{RA}=\text { Roof Area, } \mathrm{ft}^{2} \\
& \mathrm{HDD}=\text { Heating Degree Days, }{ }^{\circ} \mathrm{F} \text {-days } \\
& \mathrm{U} 1=1 / \mathrm{R} 1, \mathrm{U} \text {-Factor of Present Roof Insulation, Btu/h. } \mathrm{ft}^{2} .^{\circ} \mathrm{F} \\
& \mathrm{U} 2=1 / \mathrm{R} 2, \mathrm{U} \text {-Factor of Changed Roof Insulation, Btu/h. } \mathrm{ft}^{2} .^{\circ} \mathrm{F} \\
& \eta=\text { Seasonal Efficiency of the HVAC Unit, \% } \\
& \mathrm{HV}=\text { Heating Value of the Fuel, Btu/Gallon, Btu/kWh, Btu/ } \mathrm{ft}^{3}
\end{aligned}
$$

2. Wall Insulation: In the Wall Insulation section the user has to enter the present Wall Rvalue, the changed R-Value, efficiency of HVAC system, Wall area, select climate Zone and Fuel type. Even in this saving option the user has several wall options and upon 
selection the value in present R-value box changes accordingly, if the user knows the value then he can enter the value.

$$
\mathrm{ES}=\frac{\mathrm{WA} * \mathrm{HDD} * 24 *(\mathrm{U} 1-\mathrm{U} 2)}{* \mathrm{HV}} \quad[6.2]
$$

Where, ES = Energy Saved, MCF/yr, Gallons/yr, kWh/yr

$$
\begin{aligned}
& \mathrm{RA}=\text { Roof Area, } \mathrm{ft}^{2} \\
& \mathrm{HDD}=\text { Heating Degree Days, }{ }^{\circ} \mathrm{F} \text {-days } \\
& \mathrm{U} 1=1 / \mathrm{R} 1, \mathrm{U} \text {-Factor of Present Roof Insulation, Btu/h. } \mathrm{ft}^{2} .{ }^{\circ} \mathrm{F} \\
& \mathrm{U} 2=1 / \mathrm{R} 2, \mathrm{U} \text {-Factor of Changed Roof Insulation, Btu/h. } \mathrm{ft}^{2} .{ }^{\circ} \mathrm{F} \\
& \eta=\text { Efficiency of the HVAC Unit, \% } \\
& \mathrm{HV}=\text { Heating Value of the Fuel, Btu/Gallon, Btu/kWh, Btu/ } / \mathrm{ft}^{3}
\end{aligned}
$$

3. Window Caulking: In this section the user has to enter the total window area and number windows the caulking is needed. Select climate zones, floor number, window type and fuel type. The velocity (V) was chosen as $16 \mathrm{mph}$ for zone 4a and $18 \mathrm{mph}$ for zone $5 \mathrm{a}$, the stack co-efficient (Cs) and wind co-efficient (Cw) are obtained from [5] according the $1^{\text {st }}$, 2nd and $3^{\text {rd }}$ floors and also shielding class. $\Delta T$ is the design temperature and it is chosen as $70^{\circ} \mathrm{F}$.

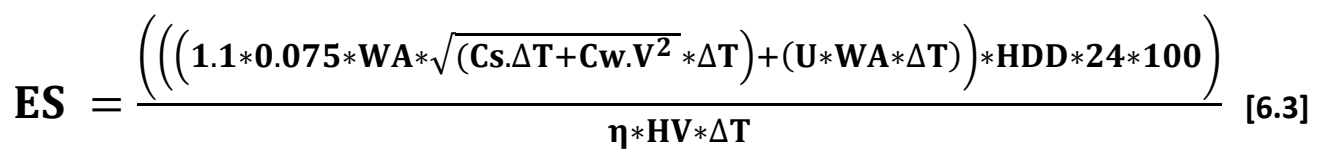

Where, ES = Energy Saved, MCF/yr, Gallons/yr, kWh/yr

$$
\begin{aligned}
& \text { WA }=\text { Window Area }, \mathrm{ft}^{2} \\
& \Delta \mathrm{T}=\text { Difference between Indoor and Outdoor temperatures of the room, }{ }^{\circ} \mathrm{F} \\
& \mathrm{Cs}=\text { Stack Co-efficient }, \mathrm{cfm}^{2} /\left(\mathrm{in}^{4} .{ }^{\circ} \mathrm{F}\right)
\end{aligned}
$$


$\mathrm{CW}=$ Wind Co-efficient, $\mathrm{cfm}^{2} /\left(\mathrm{in}^{4} \cdot \mathrm{mph}^{2}\right)$

$\mathrm{V}=$ Velocity of air, $\mathrm{mph}$

HDD = Heating Degree Days, ${ }^{\circ} \mathrm{F}$-days

$\mathrm{U}=\mathrm{U}$-factor of Window, Btu/h.ft ${ }^{2} .^{\circ} \mathrm{F}, \eta=$ Efficiency of the HVAC Unit, \%

$\mathrm{HV}=$ Heating Value of the Fuel, Btu/Gallon, Btu/kWh, Btu/ $\mathrm{ft}^{3}$

4. Window Single Paned to Double Paned: In this section the user has to enter the total window area, number of windows and HVAC unit efficiency, select climate zones and fuel type.

$$
\mathbf{E S}=\frac{\left(\left(\left(1.1 * 0.094 * \mathbf{W A} * \sqrt{\left(\mathbf{C s} . \Delta \mathbf{T}+\mathbf{C w} . \mathbf{V}^{2}\right.} * \Delta \mathbf{T}\right)+(\Delta \mathrm{U} * \mathrm{WA} * \Delta \mathrm{T})\right) * \mathrm{HDD} * \mathbf{2 4} * 100\right)}{(\boldsymbol{\eta} * \mathbf{H V} * \Delta \mathbf{T})}
$$

Where, ES = Energy Saved, MCF/yr, Gallons/yr, kWh/yr

$W A=$ Window Area, $\mathrm{ft}^{2}$,

$\Delta T=$ Difference between Indoor and Outdoor temperatures of the room, ${ }^{\circ} \mathrm{F}$

Cs $=$ Stack Co-efficient, $\mathrm{cfm}^{2} /\left(\mathrm{in}^{4} .{ }^{\circ} \mathrm{F}\right)$

$\mathrm{CW}=$ Wind Co-efficient, $\mathrm{cfm}^{2} /\left(\mathrm{in}^{4} \cdot \mathrm{mph}^{2}\right)$

$\mathrm{V}=$ Velocity of air, $\mathrm{mph}$

$\mathrm{HDD}=$ Heating Degree Days, ${ }^{\circ} \mathrm{F}$-days $\eta=$ Efficiency of the HVAC Unit, \%

$\mathrm{HV}=$ Heating Value of the Fuel, Btu/Gallon, Btu/kWh, Btu/ft ${ }^{3}$

$\Delta U=$ Difference in U-factor of Single and Double Paned

5. Door Weather-stripping: In this section the user has to enter total door area, number of doors, HVAC unit efficiency, select climate zone, fuel type, door type, and floor number. The Effective Air Leakage area is obtained from [4] for both door type's i.e. single and 
double door. The Door area comes into account when the door type is double, for a single door the Door area is ignored as the Effective leakage area is constant $1.4 \mathrm{in}^{2}$ ea.

$$
\mathrm{ES}=\frac{\left(\left(\left(1.1 * \mathrm{LA} * \mathrm{DA} * \sqrt{\left(\mathrm{Cs} . \Delta \mathrm{T}+\mathrm{Cw} . \mathrm{V}^{2}\right.} * \Delta \mathrm{T}\right)\right) * \mathrm{HDD} * \mathbf{2 4} * \mathbf{1 0 0}\right)}{\eta * \mathrm{HV} * \Delta \mathrm{T}}
$$

Where, ES = Energy Saved, MCF/yr, Gallons/yr, kWh/yr

$$
\begin{aligned}
& \mathrm{DA}=\text { Door Area, } \mathrm{ft}^{2} ; \mathrm{LA}=\text { Leakage area, } \mathrm{in}^{2} / \mathrm{ft}^{2}, \mathrm{in}^{2} \text { ea. } \\
& \Delta \mathrm{T}=\text { Difference between Indoor and Outdoor temperatures of the room, }{ }^{\circ} \mathrm{F} \\
& \mathrm{Cs}=\text { Stack Co-efficient, } \mathrm{cfm}^{2} /\left(\mathrm{in}^{4} \cdot{ }^{\circ} \mathrm{F}\right)[5] \\
& \mathrm{CW}=\text { Wind Co-efficient, } \mathrm{cfm}^{2} /\left(\mathrm{in}^{4} \cdot \mathrm{mph}^{2}\right)[5] \\
& V=\text { Velocity of air, } \mathrm{mph} \\
& \mathrm{HDD}=\text { Heating Degree Days, }{ }^{\circ} \mathrm{F}-\text { days } \\
& \mathrm{U}=\mathrm{U} \text {-factor of Door, Btu/h. } \mathrm{ft}^{2} .{ }^{\circ} \mathrm{F}, \mathrm{\eta}=\text { Efficiency of the HVAC Unit, \% } \\
& \mathrm{HV}=\text { Heating Value of the Fuel, Btu/Gallon, Btu/kWh, Btu/ } / \mathrm{ft}^{3}
\end{aligned}
$$

- Lighting Savings

1. For options, 1 to 4 that is changing T12 96 Watt bulb with Magnetic ballast to T8 59 Watt Bulb with Electronic ballast, T8 40 Watt bulb with Magnetic ballast to T8 32Watt, 28Watt and 25Watt Electronic ballast. For options 5 and 6, T8 32Watt bulbs changed to T8 28Watt and 25Watt the ballast factors are same. For options 7 and 8, Metal Halide bulbs are changed from 400 Watts to 360 Watts and there is only one bulb per fixture present. The user has to enter the number of fixtures and number of bulbs per fixture (limited to 4) and number of hours the lights are ON per year. The Ballast factor of magnetic ballast is chosen as 0.95 and electronic ballast is chosen as 0.88 . 


$$
\begin{aligned}
& \mathbf{E S}=((\mathbf{F} *(\mathbf{B} / \mathbf{F}) * \mathbf{W} \mathbf{1} * \mathbf{B F} \mathbf{1})-(\mathbf{F} * \mathbf{B} / \mathbf{F} * \mathbf{W} \mathbf{2} * \mathbf{B F} 2)) *\left(\frac{\mathrm{Hrs}}{\mathbf{1 , 0 0 0}}\right) \text { [6.6] } \\
& \begin{array}{l}
\text { Where, ES }=\text { Energy Saved, kWh/yr } \\
\mathrm{F}=\text { Number of Fixtures } \\
\text { B/F }=\text { Number of Bulbs/ Fixture } \\
\text { W1 }=\text { Bulb with Higher Wattage, Watts } \\
\text { W2 }=\text { Bulb with Lower Wattage, Watts } \\
\text { BF1, BF2 = Ballast Factor Magnetic, Electronic } \\
\text { Hrs }=\text { Hours the bulbs are ON per Year, hrs/yr }
\end{array}
\end{aligned}
$$

2. Lighting Level Requirements: According to ASHRAE 90.1 it is recommended to maintain certain amount of lighting levels in different activity areas and to check the savings. The user has to select whether there is too much lighting or too little according to the users choice, and upon selection the number of lights to be uninstalled or installed box appears. The user has to also enter the number of fixtures, bulbs, length and width of the room and hours the lights are ON per year, select type of fixture and bulbs.

$$
\begin{gathered}
\mathbf{E S}=\left(\frac{(\mathbf{F} *(\mathbf{B} / \mathbf{F}) * \mathbf{W})}{\mathbf{A}}-\mathbf{L L}\right) *\left(\frac{\mathbf{A} * \mathbf{H r s}}{\mathbf{1 , 0 0 0}}\right)[6.7] \\
\mathbf{E L}=\left(\frac{(\mathbf{F} *(\mathbf{B} / \mathbf{F}) * \mathbf{W})}{\mathbf{A}}-\mathbf{L L}\right)[6.8] \\
\mathbf{L}=\left(\frac{\mathbf{E L} * \mathbf{A}}{\mathbf{W}}\right)[6.9]
\end{gathered}
$$

Where, ES = Energy Saved, $\mathrm{kWh} / \mathrm{yr}$

$F=$ Number of Fixtures

$B / F=$ Number of Bulbs/ Fixture

W = Bulb Wattage, Watts 


$$
\begin{aligned}
& \mathrm{LL}=\text { Recommended Lighting Level of the activity area, Watt } / \mathrm{ft}^{2} \\
& \mathrm{Hrs}=\text { Hours the bulbs are ON per Year, hrs/yr } \\
& \mathrm{EL}=\text { Extra or Less Lighting Level, watt } / \mathrm{ft}^{2} \\
& \mathrm{~L}=\text { Number of Lights needed to be uninstalled or installed }
\end{aligned}
$$

- HVAC Savings

1. Duct Insulation: In this section the user has to enter the present and changed Insulation value and efficiency of HVAC system. Also has to select Climate Zone, fuel type, duct type and also enter the corresponding parameter associated with the type of duct. For the Circular Duct the user should enter the duct diameter and duct length and for Square/Rectangular Duct the user should enter duct width, depth and length. Same as before upon selection of fuel type the question appears about how much he pays for the fuel then he can enter the amount he pays per MCF or gallon or KWh of the type of fuel he selects.

$$
\mathbf{E S}=\frac{\mathrm{DA} * \mathrm{HDD} * \mathbf{2 4} *(\mathrm{U} 1-\mathrm{U} 2)}{\eta * \mathrm{HV}}
$$

Where, ES = Energy Saved, MCF/yr, Gallons/yr, kWh/yr

$$
\begin{aligned}
& \mathrm{DA}=\text { Duct Area, } \mathrm{ft}^{2} \\
& \mathrm{HDD}=\text { Heating Degree Days, }{ }^{\circ} \mathrm{F} \text {-days } \\
& \mathrm{U} 1=1 / \mathrm{R} 1, \mathrm{U} \text {-Factor of Present Duct Insulation, Btu/h. } \mathrm{ft}^{2} .^{\circ} \mathrm{F} \\
& \mathrm{U} 2=1 / \mathrm{R} 2, \mathrm{U} \text {-Factor of Changed Duct Insulation, Btu/h. } \mathrm{ft}^{2} .^{\circ} \mathrm{F} \\
& \eta=\text { Efficiency of the HVAC Unit, \% } \\
& \mathrm{HV}=\text { Heating Value of the Fuel, Btu/Gallon, Btu/kWh, Btu/ } \mathrm{ft}^{3}
\end{aligned}
$$


2. Cooling SEER: Cooling Seer is about increasing the Seasonal Energy Efficiency Ratio of the $A C$ units. In this section the user has to enter the size of the $A C$ unit in tons, present and changed SEER and selecting climate zone.

$$
\mathbf{E S}=\frac{(\mathrm{AC} * \mathbf{1 2 0 0 0} * \mathbf{C D D} * \mathbf{2 4})}{(\mathbf{1 0 0 0} *(\mathbf{S E E R} 1-\mathrm{SEER} 2) * \Delta \mathrm{T})}
$$

Where, ES = Energy Saved, kWh/yr

$$
\begin{aligned}
& A C=\text { Size of Air-Conditioning Unit, Tons } \\
& \text { CDD = Cooling Degree Days, }{ }^{\circ} \mathrm{F} \text {-days } \\
& \text { SEER1 = Seasonal Energy Efficiency Ratio of Present Unit, (Btu/h/W) } \\
& \text { SEER2 = Seasonal Energy Efficiency Ratio of Changed Unit, (Btu/h/W) } \\
& \Delta T=\text { Difference between Indoor and Outdoor temperatures of the room, }{ }^{\circ} \mathrm{F}
\end{aligned}
$$

3. Amount of Ventilation Air Needed: Most of the schools in WV bring in more air than they require and according to ASHRAE standard each student needs $10 \mathrm{cfm}$ of air for ventilation. In this section the user has to enter the number of students, amount of air (cfm) brought by HVAC units, efficiency of HVAC unit and selecting fuel type and climate zone.

$$
\mathbf{E S}=\frac{(1.1 * \mathbf{V} * \Delta \mathbf{T} * \mathbf{H D D} * \mathbf{2 4})}{(\boldsymbol{\eta} * \mathbf{H V} * \Delta \mathbf{T})}
$$

Where, ES = Energy Saved, MCF/yr, Gallons/yr, kWh/yr

$\mathrm{V}=$ Amount of air brought by HVAC units, $\mathrm{ft}^{3} / \mathrm{min}$

$\mathrm{HDD}=$ Heating Degree Days,${ }^{\circ} \mathrm{F}$-days

$\eta=$ Efficiency of the HVAC Unit, \%

$\mathrm{HV}=$ Heating Value of the Fuel, Btu/Gallon, Btu/kWh, Btu/ft ${ }^{3}$

$\Delta T=$ Difference between Indoor and Outdoor temperatures of the room, ${ }^{\circ} \mathrm{F}$ 
4. Shutoff Electric Reheat Systems: Not all schools in WV have electric HVAC units so if any of the schools do have electric reheats then this option is about switching off the reheat system in summer. In this section the user has to enter the reheat size and the number of days the reheat unit is switched off.

$$
\mathrm{ES}=\mathrm{RS} * \text { Days } * 24 \quad[6.13]
$$

Where, ES = Energy Saved, kWh/yr

$$
\mathrm{RS}=\text { Reheat Size, } \mathrm{kW}
$$

Days $=$ Days Reheat Unit is Shut Down

5. Economizer: In Air-side Economizer section the user has to enter the AC unit size and Seasonal Energy efficiency ratio (SEER) of the system and select the corresponding zone. The Cooling Load is calculated using the bin data based on the TMY data of Charleston weather file for zone $4 \mathrm{a}$ and Harrison county weather file for zone $5 \mathrm{a}$. The $5^{\circ} \mathrm{F}$ bins are shown for five months with the corresponding enthalpy, difference from return air, operating hours, and Btu-hr/lbm-air. The return air was assumed to have an enthalpy of $25 \mathrm{Btu} / \mathrm{lbm}$ based on a return air of $68^{\circ} \mathrm{F}$ and $55 \%$ humidity. The utilization factor (UF) of the economizer was assumed to be $60 \%$. The TMY data of Charleston weather file is shown in [6.1] and Harrison weather file is shown [6.2]. 
Table 6.1 TMY Data for Climate Zone 4a

\begin{tabular}{|c|c|c|c|c|c|c|}
\hline \multicolumn{7}{|l|}{ May } \\
\hline $\begin{array}{l}\text { Db temp } \\
\quad\left({ }^{\circ} \mathrm{F}\right)\end{array}$ & $\begin{array}{l}\text { Wb temp } \\
\left({ }^{\circ} \mathrm{F}\right)\end{array}$ & $\begin{array}{l}\text { Enthalpy of } \\
\text { OA (Btu/lb) }\end{array}$ & Hrs & $\begin{array}{l}\text { Enthalpy of } \\
\text { EA (Btu/lb) }\end{array}$ & $\begin{array}{c}\text { Enthalpy } \\
\text { Diff } \\
\text { (Btu/lb) }\end{array}$ & $\begin{array}{c}\text { Cooling Load } \\
\text { (Btu-hr/lb) }\end{array}$ \\
\hline 62 & 55 & 23.3 & 131 & 25 & 1.7 & 222.7 \\
\hline \multirow[t]{2}{*}{55} & 48 & 19.2 & 100 & 25 & 5.8 & 580 \\
\hline & & & & & & 802.7 \\
\hline \multicolumn{7}{|l|}{ June } \\
\hline $\begin{array}{l}\text { Db temp } \\
\quad\left({ }^{\circ} \mathrm{F}\right)\end{array}$ & $\begin{array}{l}\text { Wb temp } \\
\left({ }^{\circ} \mathrm{F}\right)\end{array}$ & $\begin{array}{l}\text { Enthalpy of } \\
\text { OA (Btu/lb) }\end{array}$ & Hrs & $\begin{array}{l}\text { Enthalpy of } \\
\text { EA (Btu/lb) }\end{array}$ & $\begin{array}{c}\text { Enthalpy } \\
\text { Diff } \\
\text { (Btu/lb) }\end{array}$ & $\begin{array}{l}\text { Cooling Load } \\
\text { (Btu-hr/lb) }\end{array}$ \\
\hline 63 & 57 & 24.5 & 71 & 25 & 0.5 & 35.5 \\
\hline \multirow[t]{2}{*}{57} & 53 & 22.1 & 47 & 25 & 2.9 & 136.3 \\
\hline & & & & & & 171.8 \\
\hline \multicolumn{7}{|l|}{ July } \\
\hline $\begin{array}{l}\text { Db temp } \\
\quad\left({ }^{\circ} \mathrm{F}\right)\end{array}$ & $\begin{array}{l}\text { Wb temp } \\
\left({ }^{\circ} \mathrm{F}\right)\end{array}$ & $\begin{array}{l}\text { Enthalpy of } \\
\text { OA (Btu/lb) }\end{array}$ & Hrs & $\begin{array}{l}\text { Enthalpy of } \\
\text { EA (Btu/llb) }\end{array}$ & $\begin{array}{c}\text { Enthalpy } \\
\text { Diff } \\
\text { (Btu/lb) }\end{array}$ & $\begin{array}{c}\text { Cooling Load } \\
\text { (Btu-hr/lb) }\end{array}$ \\
\hline 63 & 54 & 22.6 & 25 & 25 & 2.4 & 60 \\
\hline \multirow[t]{2}{*}{57} & 50 & 20.3 & 12 & 25 & 4.7 & 56.4 \\
\hline & & & & & & 116.4 \\
\hline \multicolumn{7}{|l|}{ Aug } \\
\hline $\begin{array}{l}\text { Db temp } \\
\quad\left({ }^{\circ} \mathrm{F}\right)\end{array}$ & $\begin{array}{l}\text { Wb temp } \\
\left({ }^{\circ} \mathrm{F}\right)\end{array}$ & $\begin{array}{l}\text { Enthalpy of } \\
\text { OA (Btu/lb) }\end{array}$ & Hrs & $\begin{array}{l}\text { Enthalpy of } \\
\text { EA (Btu/lb) }\end{array}$ & $\begin{array}{c}\text { Enthalpy } \\
\text { Diff } \\
\text { (Btu/lb) }\end{array}$ & $\begin{array}{l}\text { Cooling Load } \\
\text { (Btu-hr/lb) }\end{array}$ \\
\hline 60 & 54 & 22.6 & 57 & 25 & 2.4 & 136.8 \\
\hline \multirow[t]{2}{*}{56} & 50 & 20.3 & 18 & 25 & 4.7 & 84.6 \\
\hline & & & & & & 221.4 \\
\hline \multicolumn{7}{|l|}{ Sept } \\
\hline $\begin{array}{l}\text { Db temp } \\
\quad\left({ }^{\circ} \mathrm{F}\right)\end{array}$ & $\begin{array}{l}\text { Wb temp } \\
\left({ }^{\circ} \mathrm{F}\right)\end{array}$ & $\begin{array}{l}\text { Enthalpy of } \\
\text { OA (Btu/lb) }\end{array}$ & Hrs & $\begin{array}{l}\text { Enthalpy of } \\
\text { EA (Btu/lb) }\end{array}$ & $\begin{array}{c}\text { Enthalpy } \\
\text { Diff } \\
\text { (Btu/lb) }\end{array}$ & $\begin{array}{l}\text { Cooling Load } \\
\text { (Btu-hr/lb) }\end{array}$ \\
\hline 60 & 55 & 23.3 & 122 & 25 & 1.7 & 207.4 \\
\hline \multirow[t]{2}{*}{55} & 51 & 20.9 & 88 & 25 & 4.1 & 360.8 \\
\hline & & & & & & 568.2 \\
\hline Total & & & & & & 1880.5 \\
\hline
\end{tabular}


Table 6.2 TMY Data for Climate Zone 5a

\begin{tabular}{|c|c|c|c|c|c|c|}
\hline \multicolumn{7}{|l|}{ May } \\
\hline $\begin{array}{l}\text { Db temp } \\
\qquad\left({ }^{\circ} \mathrm{F}\right)\end{array}$ & $\begin{array}{l}\text { Wb temp } \\
\quad\left({ }^{\circ} \mathrm{F}\right)\end{array}$ & $\begin{array}{l}\text { Enthalpy of } \\
\text { OA (Btu/lb) }\end{array}$ & Hrs & $\begin{array}{c}\text { Enthalpy } \\
\text { of EA } \\
\text { (Btu/lb) }\end{array}$ & $\begin{array}{c}\text { Enthalpy } \\
\text { Diff (Btu/lb) }\end{array}$ & $\begin{array}{l}\text { Cooling Load } \\
\text { (Btu-hr/lb) }\end{array}$ \\
\hline 62 & 55 & 23.3 & 272 & 25 & 1.7 & 462.4 \\
\hline \multirow[t]{2}{*}{55} & 48 & 19.2 & 180 & 25 & 5.8 & 1044 \\
\hline & & & & & & 1506.4 \\
\hline \multicolumn{7}{|l|}{ June } \\
\hline $\begin{array}{l}\text { Db temp } \\
\quad\left({ }^{\circ} \mathrm{F}\right)\end{array}$ & $\begin{array}{l}\text { Wb temp } \\
\quad\left({ }^{\circ} \mathrm{F}\right)\end{array}$ & $\begin{array}{l}\text { Enthalpy of } \\
\text { OA (Btu/lb) }\end{array}$ & Hrs & $\begin{array}{c}\text { Enthalpy } \\
\text { of EA } \\
\text { (Btu/lb) }\end{array}$ & $\begin{array}{c}\text { Enthalpy } \\
\text { Diff (Btu/lb) }\end{array}$ & $\begin{array}{l}\text { Cooling Load } \\
\text { (Btu-hr/lb) }\end{array}$ \\
\hline 63 & 58 & 24.5 & 113 & 25 & 0.5 & 35.5 \\
\hline \multirow[t]{2}{*}{57} & 53 & 22.1 & 56 & 25 & 2.9 & 162.4 \\
\hline & & & & & & 197.9 \\
\hline \multicolumn{7}{|l|}{ July } \\
\hline $\begin{array}{l}\text { Db temp } \\
\quad\left({ }^{\circ} \mathrm{F}\right)\end{array}$ & $\begin{array}{l}\text { Wb temp } \\
\quad\left({ }^{\circ} \mathrm{F}\right)\end{array}$ & $\begin{array}{l}\text { Enthalpy of } \\
\text { OA (Btu/lb) }\end{array}$ & Hrs & $\begin{array}{c}\text { Enthalpy } \\
\text { of EA } \\
\text { (Btu/lb) }\end{array}$ & $\begin{array}{c}\text { Enthalpy } \\
\text { Diff (Btu/lb) }\end{array}$ & $\begin{array}{l}\text { Cooling Load } \\
\text { (Btu-hr/lb) }\end{array}$ \\
\hline 63 & 54 & 22.6 & 82 & 25 & 2.4 & 196.8 \\
\hline \multirow[t]{2}{*}{57} & 50 & 20.3 & 17 & 25 & 4.7 & 79.9 \\
\hline & & & & & & 276.7 \\
\hline \multicolumn{7}{|l|}{ Aug } \\
\hline $\begin{array}{l}\text { Db temp } \\
\qquad\left({ }^{\circ} \mathrm{F}\right)\end{array}$ & $\begin{array}{l}\text { Wb temp } \\
\quad\left({ }^{\circ} \mathrm{F}\right)\end{array}$ & $\begin{array}{l}\text { Enthalpy of } \\
\text { OA (Btu/lb) }\end{array}$ & Hrs & $\begin{array}{c}\text { Enthalpy } \\
\text { of EA } \\
\text { (Btu/lb) }\end{array}$ & $\begin{array}{c}\text { Enthalpy } \\
\text { Diff (Btu/lb) }\end{array}$ & $\begin{array}{l}\text { Cooling Load } \\
\text { (Btu-hr/lb) }\end{array}$ \\
\hline 60 & 54 & 22.6 & 96 & 25 & 2.4 & 230.4 \\
\hline \multirow[t]{2}{*}{56} & 50 & 20.3 & 29 & 25 & 4.7 & 136.3 \\
\hline & & & & & & 366.7 \\
\hline \multicolumn{7}{|l|}{ Sept } \\
\hline $\begin{array}{l}\text { Db temp } \\
\quad\left({ }^{\circ} \mathrm{F}\right)\end{array}$ & $\begin{array}{l}\text { Wb temp } \\
\left({ }^{\circ} \mathrm{F}\right)\end{array}$ & $\begin{array}{l}\text { Enthalpy of } \\
\text { OA (Btu/lb) }\end{array}$ & Hrs & $\begin{array}{c}\text { Enthalpy } \\
\text { of EA } \\
\text { (Btu/lb) }\end{array}$ & $\begin{array}{c}\text { Enthalpy } \\
\text { Diff (Btu/lb) }\end{array}$ & $\begin{array}{c}\text { Cooling Load } \\
\text { (Btu-hr/lb) }\end{array}$ \\
\hline 60 & 55 & 23.3 & 130 & 25 & 1.7 & 221 \\
\hline \multirow[t]{2}{*}{55} & 51 & 20.9 & 87 & 25 & 4.1 & 356.7 \\
\hline & & & & & & 577.7 \\
\hline Total & & & & & & 2925.4 \\
\hline
\end{tabular}




$$
\mathrm{ES}=\frac{(\mathrm{AC} * 400 * \mathrm{CL} * 60 * 0.0769 * \mathrm{UF} * 293)}{(1,000,000 * \mathrm{SEER} * 0.293)}
$$

Where, ES = Energy Saved, $\mathrm{kWh} / \mathrm{yr}$

$A C=$ Size of Air Conditioning Unit, Tons

$\mathrm{CL}=$ Cooling Load Reduction, Btu-hr/lb

UF = Utilization Factor

SEER = Seasonal Energy Efficiency Ratio of AC unit, (Btu/hr/W)

6. Staged Make-up Air Unit (MAU): Schools use Make-up air units in kitchen which run at full blast from 6:00 am to $11: 00$ am and there is a big savings potential. The user has to enter MAU size in cubic-foot/minute and select the climate zone. The calculations are done in the same way as the Economizer's; instead of cooling load there is heating load. As the unit runs for 5 hours every day the $5^{\circ} \mathrm{F}$ bins of the TMY data were taken from 6:00 am to $11: 00$ am below $70^{\circ} \mathrm{F}$. The inside air is assumed to have an enthalpy of 25.5 Btu/lbm based on a return air of $70^{\circ} \mathrm{F}$ and $50 \%$ humidity. The tables are shown for two weather zones with the corresponding enthalpy, difference from inside air, operating hours, and Btu-hr/lbm-air. The operating hours are calculated for all months where the temperature is below $70^{\circ} \mathrm{F}$. 
Table 6.3 TMY Data for climate zone 4a

\begin{tabular}{|c|c|c|c|c|c|c|}
\hline $\begin{array}{c}\text { Db temp } \\
\left({ }^{\circ} \mathbf{F}\right)\end{array}$ & $\begin{array}{c}\text { Wb temp } \\
\left({ }^{\circ} \mathbf{F}\right)\end{array}$ & $\begin{array}{c}\text { Enthalpy of OA } \\
(\text { Btu/lb) }\end{array}$ & $\begin{array}{c}\text { Hours } \\
(\mathbf{h r s} / \mathbf{y r})\end{array}$ & $\begin{array}{c}\text { Enthalpy } \\
\text { of IA } \\
(\text { Btu/lb) }\end{array}$ & $\begin{array}{c}\text { Enthalpy } \\
\text { Diff } \\
(\text { Btu/lb) }\end{array}$ & $\begin{array}{c}\text { Heating Load } \\
\text { (Btu-hr/lbm-air) }\end{array}$ \\
\hline-12 & -12.5 & -2.6 & 3 & 25.5 & 28.1 & 84.3 \\
\hline-7 & -7.7 & -1.3 & 8 & 25.5 & 26.8 & 214.4 \\
\hline-2 & -2.5 & 0.14 & 9 & 25.5 & 25.36 & 228.24 \\
\hline 3 & 2.7 & 1.6 & 2 & 25.5 & 23.9 & 47.8 \\
\hline 7 & 6.5 & 2.75 & 19 & 25.5 & 22.75 & 432.25 \\
\hline 12 & 11.5 & 4.25 & 30 & 25.5 & 21.25 & 637.5 \\
\hline 18 & 16.8 & 6 & 27 & 25.5 & 19.5 & 526.5 \\
\hline 22 & 20.5 & 7.3 & 66 & 25.5 & 18.2 & 1201.2 \\
\hline 26 & 24 & 8.5 & 112 & 25.5 & 17 & 1904 \\
\hline 33 & 31 & 11.4 & 132 & 25.5 & 14.1 & 1861.2 \\
\hline 37 & 35 & 13 & 167 & 25.5 & 12.5 & 2087.5 \\
\hline 42 & 40 & 15.2 & 171 & 25.5 & 10.3 & 1761.3 \\
\hline 48 & 44.5 & 17.5 & 175 & 25.5 & 8 & 1400 \\
\hline 53 & 48 & 19.2 & 171 & 25.5 & 6.3 & 1077.3 \\
\hline 57 & 50 & 20.2 & 203 & 25.5 & 5.3 & 1075.9 \\
\hline 63 & 55 & 23.4 & 190 & 25.5 & 2.1 & 399 \\
\hline 66 & 58 & 25 & 256 & 25.5 & 0.5 & 128 \\
\hline & & & & & & 15066.39 \\
\hline
\end{tabular}

Table 6.4 TMY Data for climate zone 5a

\begin{tabular}{|c|c|c|c|c|c|c|}
\hline $\begin{array}{c}\text { Db temp } \\
\left({ }^{(} \mathbf{F}\right)\end{array}$ & $\begin{array}{c}\mathbf{W b} \text { temp } \\
\left({ }^{\circ} \mathbf{F}\right)\end{array}$ & $\begin{array}{c}\text { Enthalpy of OA } \\
(\mathbf{B t u} / \mathbf{l b})\end{array}$ & $\begin{array}{c}\text { Hours } \\
(\mathbf{h r s} / \mathbf{y r})\end{array}$ & $\begin{array}{c}\text { Enthalpy of } \\
\text { EA (Btu/lb) }\end{array}$ & $\begin{array}{c}\text { Enthalpy } \\
\text { Diff (Btu/lb) }\end{array}$ & $\begin{array}{c}\text { Heating Load } \\
\text { (Btu-hr/lbm-air) }\end{array}$ \\
\hline 7 & 6.5 & 2.75 & 6 & 25.5 & 22.75 & 136.5 \\
\hline 12 & 11.5 & 4.25 & 20 & 25.5 & 21.25 & 425 \\
\hline 18 & 16.8 & 6 & 49 & 25.5 & 19.5 & 955.5 \\
\hline 22 & 20.5 & 7.3 & 104 & 25.5 & 18.2 & 1892.8 \\
\hline 26 & 24 & 8.5 & 122 & 25.5 & 17 & 2074 \\
\hline 33 & 31 & 11.4 & 212 & 25.5 & 14.1 & 2989.2 \\
\hline 37 & 35 & 13 & 193 & 25.5 & 12.5 & 2412.5 \\
\hline 42 & 40 & 15.2 & 120 & 25.5 & 10.3 & 1236 \\
\hline 48 & 44.5 & 17.5 & 174 & 25.5 & 8 & 1392 \\
\hline 53 & 48 & 19.2 & 173 & 25.5 & 6.3 & 1089.9 \\
\hline 57 & 50 & 20.2 & 154 & 25.5 & 5.3 & 816.2 \\
\hline 63 & 55 & 23.4 & 233 & 25.5 & 2.1 & 489.3 \\
\hline 66 & 58 & 25 & 200 & 25.5 & 0.5 & 100 \\
\hline & & & & & & $\mathbf{1 6 0 0 8 . 9}$ \\
\hline
\end{tabular}




$$
\mathrm{ES}=\frac{(\mathrm{MS} * \mathrm{HL} * 60 * 0.0769 * 293)}{(1000000)}[6.15]
$$

Where, ES = Energy Saved, kWh/yr

MS = Make-up air Unit size, $\mathrm{cfm}$

$\mathrm{HL}=$ Heating Load Reduction, Btu-hr/lb

7. Setback Controls: In this section the user has to enter the areas and R-value's of roof, wall, window, door, floor, outside air brought by HVAC units, heating season unoccupied hours and number of HVAC units. The $\triangle T$ was assumed to be $7^{\circ} \mathrm{F}$ which is the decreasing of temperature during unoccupied hours of winter season. The reason for not including the cooling setback that is increasing the set temperature by $4^{\circ} \mathrm{F}$ is, the schools are closed during the summer session for the months of July and August and also during the rest of the heating months May, June and August the average night time temperatures are between 65 to $70^{\circ} \mathrm{F}$ which is lesser than the setback temperature. So it is advised for the schools just to shut down the units in weekends and after school hours in summer months.

$$
\mathbf{E S}=[\boldsymbol{\Sigma}(\text { Aper } \times \mathbf{U})+\text { qvent }] * \Delta \mathbf{T} * \mathbf{h r} / \mathbf{H V}[6.16]
$$

Where, ES = Energy Saved, MCF/yr, Gallons/yr, kWh/yr

Aper $=$ Surface Area of Perimeter Envelope, $\mathrm{ft}^{2}$

$\mathrm{U}=$ Effective $\mathrm{U}$-factors of thermal Envelope, Btu/h. $\mathrm{ft}^{2}{ }^{\circ} \mathrm{F}$

qvent $=$ Ventilation Load, Btu/hr. ${ }^{\circ} \mathrm{F}$

$\Delta T=$ Difference in temperature of occupied and unoccupied hours, ${ }^{\circ} \mathrm{F}$

$\mathrm{hr}=$ Hours unoccupied, $\mathrm{hr}$

$\mathrm{HV}=$ Heating Value of the Fuel, Btu/Gallon, Btu/kWh, Btu/ft ${ }^{3}$ 
8. HVAC Maintenance: In this section, the user is provided with some advisory information regarding the savings got by the maintenance of different types of HVAC systems. The information provided in this option are cleaning cooling coils, cleaning filters and cooling towers.

- Service Water Heating Savings

1. Excess Oxygen Sensor: In this section the user has to enter boiler size, amount of present and changed excess air percentage, number of hours the boiler is $\mathrm{ON}$ and fuel type. The graphs show the \% Excess air vs. Efficiency plots for two fuels and there are also equations which have $\mathrm{C} 1$ and $\mathrm{C} 2$ values. The $\mathrm{C} 1$ values for Natural gas and Fuel oil are -0.0941 and -0.0948 respectively and $C 2$ are 79.1 and 79.517 . In the bottom right corner of each graph there is an equation which is about the \% Excess air vs. \% oxygen.

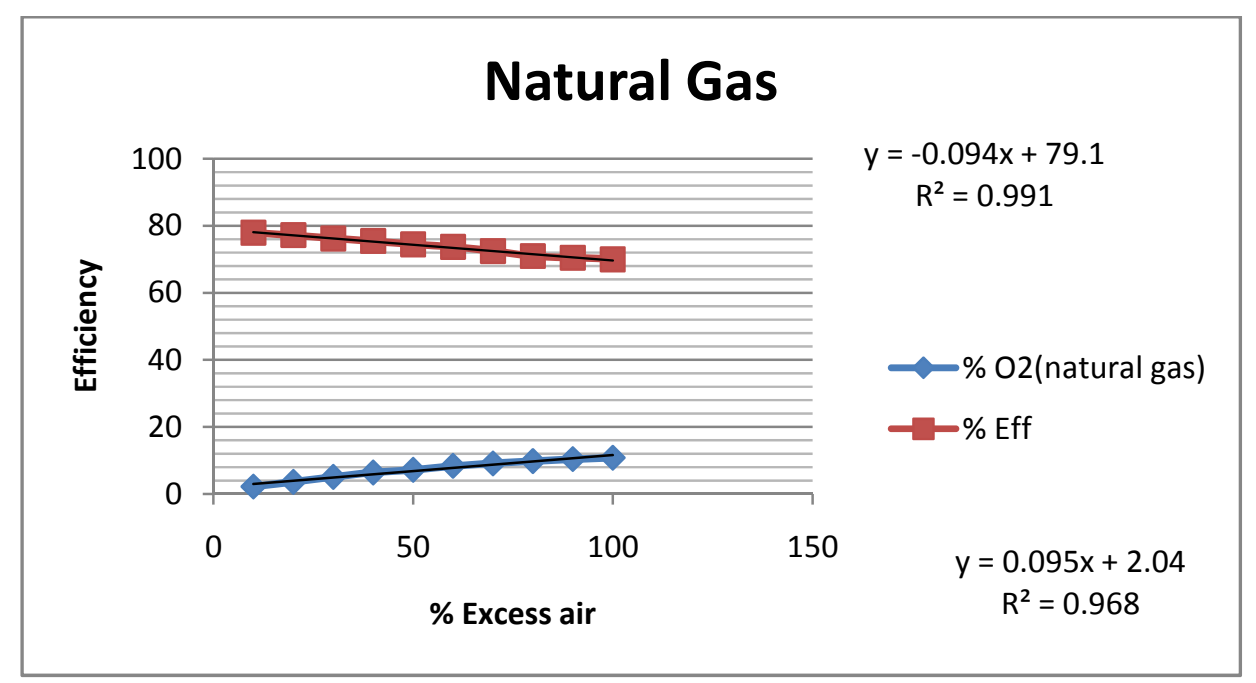

Figure 6.1 Graph for Natural Gas (\% Excess air Vs. Efficiency) 


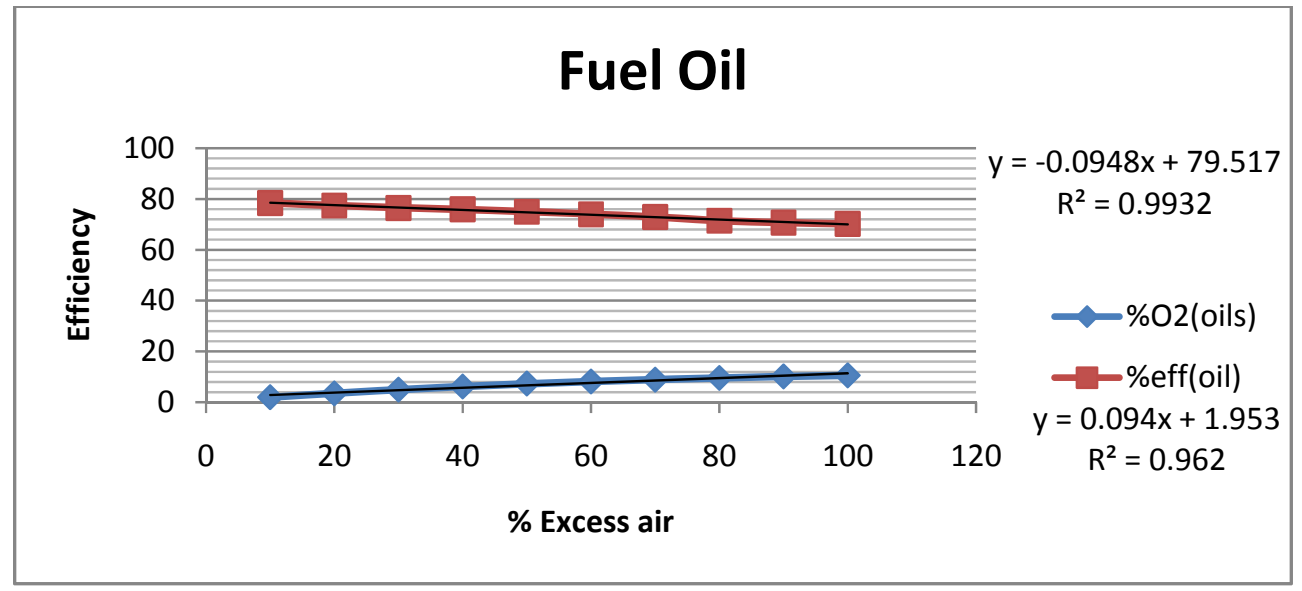

Figure 6.2 Graph for Fuel Oil (\%Excess air Vs. Efficiency)

$$
\mathbf{E S}=\frac{(\mathrm{BS} * \mathrm{HDD} *((\mathrm{C} 1 * \text { Excess air2 })+\mathrm{C} 2)-(\mathbf{C 1} * \text { Excess air1 })+\mathrm{C} 2)))}{(\mathbf{1 0 0} * \Delta \mathrm{T} * \mathrm{HV})}
$$

Where, ES = Energy Saved, MCF/yr, Gallons/yr, kWh/yr

BS = Boiler Size, Btu/hr

Excess air $2=$ Percent of excess air changed, \%

Excess air $1=$ Percent of excess air Present, $\%$

$\mathrm{C} 1, \mathrm{C} 2$ = Constants from graphs

$\mathrm{HV}=$ Heating Value of the Fuel, Btu/Gallon, Btu/kWh, Btu/ft ${ }^{3}$

2. Heater Insulation: In this section the user has to enter present and changed heater insulation, surface area of the heater, efficiency of heater and select fuel type.

$$
\mathbf{E S}=\frac{(\mathrm{U} 1-\mathrm{U} 2) * \mathrm{HA} * \Delta \mathrm{T} * \mathrm{OH}}{\eta * \mathrm{HV}}[6.18]
$$

Where, ES = Energy Saved, MCF/yr, Gallons/yr, kWh/yr

$$
\mathrm{HA}=\text { Heater Area, } \mathrm{ft}^{2}
$$




$$
\begin{aligned}
& \mathrm{U} 1=1 / \mathrm{R} 1, \mathrm{U} \text {-Factor of Present Duct Insulation, Btu/h.ft}{ }^{2} .{ }^{\circ} \mathrm{F} \\
& \mathrm{U} 2=1 / \mathrm{R} 2, \mathrm{U} \text {-Factor of Changed Duct Insulation, Btu/h. } \mathrm{ft}^{2} .{ }^{\circ} \mathrm{F} \\
& \eta=\text { Efficiency of the HVAC Unit, \% } \\
& \mathrm{HV}=\text { Heating Value of the Fuel, Btu/Gallon, Btu/kWh, Btu/ft }{ }^{3} \\
& \Delta \mathrm{T}=\text { Difference between inlet and outlet water temperatures, }{ }^{\circ} \mathrm{F} \\
& \mathrm{OH}=\text { Heater Operating Hours, } \mathrm{hrs} / \mathrm{yr}
\end{aligned}
$$

3. Instantaneous Heater: In this section the user has to enter water heater size, number of hours the water heater is used, and efficiency of water heater and select fuel type. In most of the boilers stand-by losses account for $10 \%$ and so for the calculation purpose they are assumed to be $10 \%$ and the combustion losses are assumed as 1-Efficiency of heater.

$$
\mathrm{ES}=\frac{\mathrm{HS} * \mathrm{OH} *(1-\mathrm{CL}-\mathrm{SB})}{(\mathrm{HV})}[6.19]
$$

Where, ES = Energy Saved, MCF/yr, Gallons/yr, kWh/yr

$$
\begin{aligned}
& \mathrm{HS}=\text { Heater Size, Btu/hr } \\
& \mathrm{OH}=\text { Heater operating hours, } \mathrm{hrs} / \mathrm{yr} \\
& \mathrm{CL}=\text { Combustion Losses }=1-\text { Efficiency of heater } \\
& \mathrm{SB}=\text { Standby Losses } \\
& \mathrm{HV}=\text { Heating Value of the Fuel, Btu/Gallon, Btu/kWh, Btu/ft }{ }^{3}
\end{aligned}
$$

4. Water Heater Efficiency: In this section the user has to enter heater size, hours it is used, present and changed efficiency of the heaters and selecting fuel type. 


$$
\mathrm{ES}=\frac{(\mathrm{HS} * \mathrm{OH}) *(\mathrm{E} 2-\mathrm{E} 1)}{\mathrm{HV}}[6.20]
$$

Where, ES = Energy Saved, MCF/yr, Gallons/yr, kWh/yr

$$
\begin{aligned}
& \mathrm{HS}=\text { Heater Size, Btu/hr } \\
& \mathrm{OH}=\text { Heater operating hours, hrs/yr } \\
& \mathrm{E} 2=\text { Changed heater Efficiency, } \% \\
& \mathrm{E} 1=\text { Present heater Efficiency, } \% \\
& \mathrm{HV}=\text { Heating Value of the Fuel, Btu/Gallon, Btu/kWh, Btu/ft }{ }^{3}
\end{aligned}
$$

5. Boiler Maintenance: Most of the boilers present in the schools have scale formations in the inner walls of the boiler because of which the efficiency is decreased. In this section the user has to enter the boiler size, select the scale thickness in inches, climate zone and fuel type. Upon selecting the thickness the user is provided with the percentage loss of efficiency in the boiler. The Scale Thickness and Percentage Efficiency Loss (\%) are obtained from [43]. The savings are provided by performing chemical treatment to clean the boiler.

$$
\mathrm{ES}=\frac{(\mathrm{BS} * \mathrm{HDD} * 24 * \mathrm{E})}{\Delta \mathrm{T} * \mathrm{HV}}[6.21]
$$

Where, ES = Energy Saved, MCF/yr, Gallons/yr, kWh/yr

BS = Boiler Size, Btu/hr

HDD = Heating Degree Days, ${ }^{\circ} \mathrm{F}-$ Days

$E=$ Percentage of Efficiency loss (\%)

$\Delta \mathrm{T}=$ Difference in Indoor and Outdoor Temperature, $70^{\circ} \mathrm{F}$

$\mathrm{HV}=$ Heating Value of the Fuel, Btu/Gallon, Btu/kWh, Btu/ft ${ }^{3}$ 
6. Water Temperature: In this section the calculations are done based on the water consumption of the students in different types of schools one the Elementary School and the other Junior or High School. According to [39] each student on an average day in "Elementary school" consumes 0.6 gallons/day and in "Junior or High School" 1.8 gallons/day. Considering the above condition the school the user has to select the type of school, enter the number of students, select heated water temperature, and enter the water heater efficiency, and select fuel type, climate zone.

$$
\mathbf{E S}=\frac{\mathbf{G} * \mathrm{NS} * 8.34 * \mathrm{Cp} * \Delta \mathrm{T} * \mathrm{ND} * \mathbf{2 4}}{(\boldsymbol{\eta} * \mathrm{HV})}[6.22]
$$

Where, ES = Energy Saved, MCF/yr, Gallons/yr, kWh/yr

$\mathrm{G}=$ Gallons Consumed by a student, Gallons/day

$\mathrm{Cp}=$ Specific Heat Capacity of Water, Btu/lbm- ${ }^{\circ} \mathrm{F}$

$\Delta \mathrm{T}=$ Difference between required and present water temperatures, ${ }^{\circ} \mathrm{F}$

ND = Number of days the heater is ON per year

$\eta=$ Efficiency of the HVAC Unit, \%

$\mathrm{HV}=$ Heating Value of the Fuel, Btu/Gallon, Btu/kWh, Btu/ $\mathrm{ft}^{3}$

7. Pipe Insulation: In this section the insulation of water pipes serving the water coils to HVAC units and water carried to the faucets and domestic water usage is provided. The heat loss factors are obtained from [42]. The user has to select the Pipe Internal Diameter, Insulation value, climate zone, fuel type and enter length of the pipe.

$$
\mathrm{ES}=\frac{(\mathrm{L} * \mathrm{HDD} * 24 *(\mathrm{U} 1-\mathrm{U} 2))}{(\Delta \mathrm{T} * \mathrm{HV})}[6.23]
$$

Where, ES = Energy Saved, MCF/yr, Gallons/yr, kWh/yr 
$L=$ Length of the pipe, $\mathrm{ft}$

HDD $=$ Heating Degree Days, ${ }^{\circ} \mathrm{F}-$ Days

$\mathrm{U} 1, \mathrm{U} 2=$ Bare Pipe and Insulated Pipe Heat loss factor, Btu/h. ft. ${ }^{\circ} \mathrm{F}$

$\Delta \mathrm{T}=$ Difference between required and present water temperatures, ${ }^{\circ} \mathrm{F}$

$\mathrm{HV}=$ Heating Value of the Fuel, Btu/Gallon, Btu/kWh, Btu/ $\mathrm{ft}^{3}$

- Miscellaneous Savings

1. Computer Low Power Mode: Computer low power mode is the savings obtained by putting the computer in a hyper sleep mode. There is a message screen which is displayed about ENERGY STAR's EZ GPO \& EZ Wizard tool.

2. Shower Heads: Changing of shower heads does impact some of the energy usage and also saves water. In this section the user has to enter the present and changed shower head ratings, shower running time in the whole year, number of shower heads changed, and efficiency of the water heater and select fuel type. The water is heated from $55^{\circ} \mathrm{F}$ which is ground water temperature to $140^{\circ} \mathrm{F}$; the difference is shown as 85 in the equation.

$$
\mathbf{E S}=\frac{(\mathrm{SH} 1-\mathrm{SH} 2) * \mathrm{ST} * \mathrm{NSH} * \mathbf{8 . 3 4} * 85}{\eta * \mathrm{HV}}
$$

Where, ES = Energy Saved, MCF/yr, Gallons/yr, kWh/yr

SH1 = Present Shower Head, gpm

$\mathrm{SH} 2=$ Changed Shower Head, gpm

ST = Shower usage time, $\mathrm{min} / \mathrm{yr}$

$\mathrm{NSH}=$ Number of Shower Heads 
$\eta=$ Efficiency of the HVAC Unit, \%

$\mathrm{HV}=$ Heating Value of the Fuel, Btu/Gallon, Btu/kWh, Btu/ft ${ }^{3}$

3. Faucet (aerator): Faucet (Aerator) changing also helps some energy and water savings. In this section the user has to present and changed faucet ratings, faucet usage time for a year, number of faucets changed, and efficiency of the water heater and select fuel type.

$$
\mathbf{E S}=\frac{(\mathbf{F 1}-\mathrm{F} 2) * \mathrm{FT} * \mathrm{FH} * 8.34 * 85}{\eta * \mathrm{HV}}[6.25]
$$

Where, ES = Energy Saved, MCF/yr, Gallons/yr, kWh/yr

SH1 $=$ Present Shower Head, gpm

$\mathrm{SH} 2=$ Changed Shower Head, gpm

$\mathrm{ST}=$ Shower usage time, $\mathrm{min} / \mathrm{yr}$

$\mathrm{NSH}=$ Number of Shower Heads

$\eta=$ Efficiency of the HVAC Unit, \%

$\mathrm{HV}=$ Heating Value of the Fuel, Btu/Gallon, Btu/kWh, Btu/ft ${ }^{3}$

4. Pool Covers: Some schools in WV have indoor pools and they do not use a pool covers when the pool is not in service but heated. In this section the user has to enter the pool area, efficiency of the heater, and the hours the pool is not in service and select fuel type. For indoor pools, water temperature is assumed as $80^{\circ} \mathrm{F}$ and air temperature as $75^{\circ} \mathrm{F}$ and relative humidity $50 \%$ and pressures are $\mathrm{Pw}=0.507$ psia and $\mathrm{Pa}=0.211$ psia [20].

$$
\begin{gathered}
\mathbf{E S}=\frac{((\mathbf{E L}+\mathbf{C L}+\mathbf{R L}) * \mathbf{O H})}{\eta+\mathbf{H V}}[6.26] \\
\text { EL }=\mathbf{0 . 2 0 4} * \mathbf{1 0 5 0} *(\mathbf{P w}-\mathbf{P a}) * \mathbf{P A}[6.27]
\end{gathered}
$$




$$
\begin{gathered}
\text { CL }=0.38 *(\mathbf{T w}-\mathbf{T a})^{0.25} *(\mathbf{T w}-\mathbf{T a}) * \mathbf{P A} \quad[6.28] \\
\mathbf{R L}=\mathbf{0 . 1 7 4} *\left(10^{-8}\right) * \mathbf{0 . 9 3} *\left[(\mathbf{4 6 0}+\mathbf{T w})^{4}-(460+\mathbf{T a})^{4}\right] * \mathbf{P A} \quad[6.29]
\end{gathered}
$$

Where, ES = Energy Saved, MCF/yr, Gallons/yr, kWh/yr

$$
\begin{aligned}
& \mathrm{PA}=\text { Pool Area, } \mathrm{ft}^{2} \\
& \mathrm{EL}=\text { Evaporative Loss, Btu/hr } \\
& \mathrm{CL}=\text { Convective Loss, Btu/hr} \\
& \mathrm{RL}=\text { Radiant Loss, Btu/hr} \\
& \mathrm{Pw}, \mathrm{Pa}=\text { Pressure of Water, air, Psia } \\
& \mathrm{Tw}, \mathrm{Ta}=\text { Temperature of Water, air, }{ }^{\circ} \mathrm{F} \\
& \mathrm{HV}=\text { Heating Value of the Fuel, Btu/Gallon, Btu/kWh, Btu/ft }{ }^{3} \\
& \mathrm{OH}=\text { Hours pool is heated but not used, hrs } / \mathrm{yr}
\end{aligned}
$$

5. Faucet Leakage: In schools, the leaks contribute some amount of water and energy losses. Taking this into consideration the user has to enter the number of leaking faucets and select the leakage rate of water for example 1 drip/minute, 2 drips/minute and so on so forth till 120 drips/minute. Volume of each faucet drip was assumed to be 0.25 milliliter ( $\mathrm{ml}$ [38], and taking that into consideration one gallon of water equals 15,140 drips.

$$
\begin{gathered}
\mathrm{WS}=\frac{(\mathrm{NF} * \mathrm{LR} * 24 * 60 * 365)}{15140}[6.30] \\
\mathrm{ES}=\frac{\mathrm{WS} * 8.34 * \Delta \mathrm{T}}{\mathrm{HV}}[6.31]
\end{gathered}
$$

Where, ES = Energy Saved, MCF/yr, Gallons/yr, kWh/yr

$$
\text { WS }=\text { Water Saved, gallons } / y r
$$




$$
\begin{aligned}
& N F=\text { Number of Faucets } \\
& L R=\text { Leakage rate, drips } / \text { min } \\
& \Delta T=\text { Temperature Difference between Inlet and Outlet Water Temperature }\left({ }^{\circ} \mathrm{F}\right)
\end{aligned}
$$

\section{Cost Estimates}

Several websites and books where cross-checked in order to determine installation costs for each recommendation type which are shown in the expert system. The Cost estimates of each selection, formulae and reason for using the formulae are given below.

- Building Envelope Savings

1. Roof Insulation: In the Roof Insulation section the cost estimation was done using the fiberglass, blankets or batts, paper or foil backing insulation [17]. The costs of R-19, R-21, $\mathrm{R}-25, \mathrm{R}-30$ and $\mathrm{R}-38$ which include labor, operation and profit costs are plotted on a graph with R-value on $\mathrm{X}$-axis and cost on $\mathrm{Y}$-axis. According to the graph generated by MS-excel, there is an equation which is regressed from the data points and using this equation the installation cost is calculated.

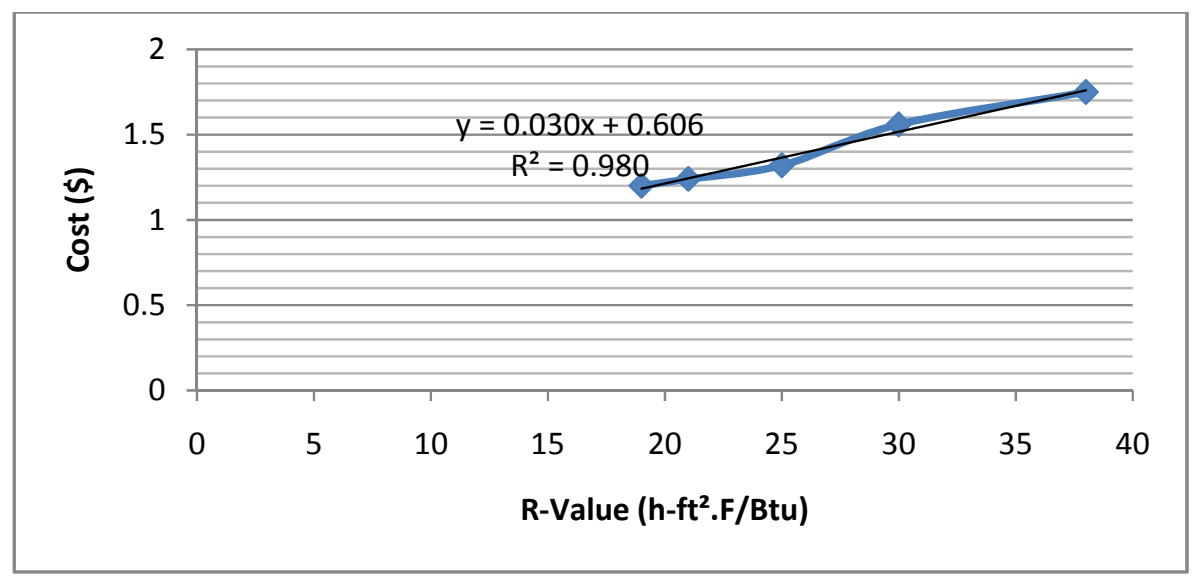

Figure 7.1 Roof R-value (h- $\mathrm{ft}^{2}$.F/Btu) vs. Cost (\$) 


$$
\text { Installation } \operatorname{Cost}(\$)=((0.0304 *(\mathbf{R 2}-\mathbf{R} 1)+0.6066) * \mathbf{R A}[7.1]
$$

Where,

$$
\begin{aligned}
& \mathrm{R} 2=\text { Changed } \mathrm{R}-\text { Value, } \mathrm{h} \cdot \mathrm{ft}^{2} . \mathrm{F} / \text { Btu } \\
& \mathrm{R} 1=\text { Present R-Value, } \mathrm{h} \cdot \mathrm{ft}^{2} . \mathrm{F} / \text { Btu } \\
& \mathrm{RA}=\text { Roof Area }, \mathrm{ft}^{2}
\end{aligned}
$$

2. Wall Insulation: Same as the Roof Insulation section, the cost of wall insulation R-11, R13 and R-15 Kraft faced fiberglass insulation [17] costs are plotted on a graph with Rvalue on $\mathrm{X}$-axis and cost on $\mathrm{Y}$-axis.

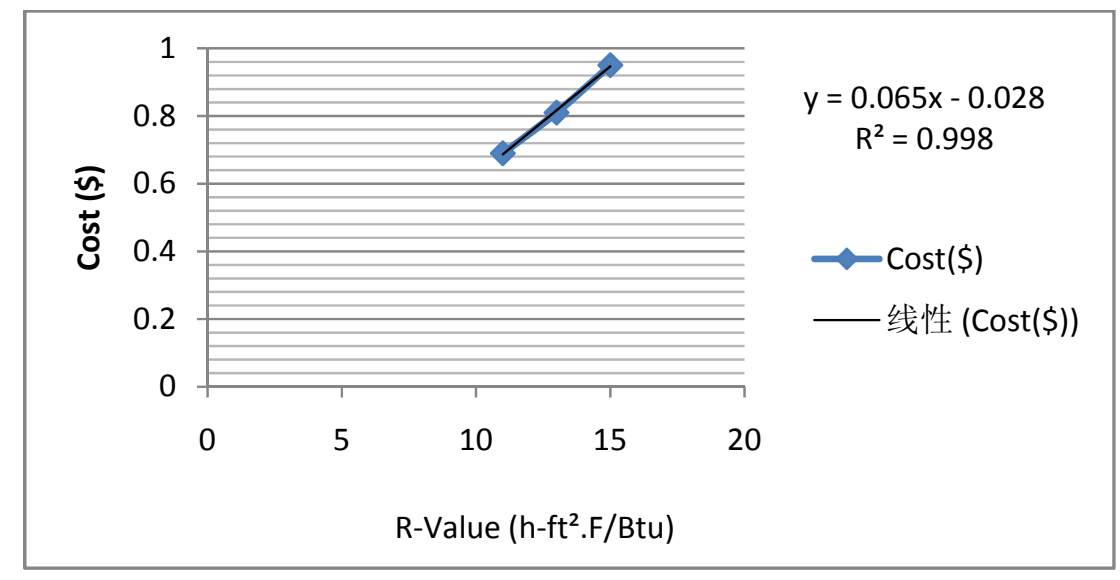

Figure 7.2 Wall R-value (h-ft2.F/Btu) vs. Cost (\$)

$$
\text { Installation } \operatorname{Cost}(\$)=((0.065 *(\mathbf{R} 2-\mathbf{R} 1)-\mathbf{0 . 0 2 8 3}) * \text { WA [7.2] }
$$

Where, $\mathrm{R} 2$ = Changed R-Value, $\mathrm{h} \cdot \mathrm{ft}^{2}$.F/Btu

$$
\begin{aligned}
& \mathrm{R} 1=\text { Present } \mathrm{R}-\text { Value, } \mathrm{h} \cdot \mathrm{ft}^{2} . \mathrm{F} / \text { Btu } \\
& \mathrm{WA}=\text { Wall Area, } \mathrm{ft}^{2}
\end{aligned}
$$


3. Window Caulking: In this section as the user enters the number of windows the equation is initialized. This cost data was from [31]. The cost also includes the caulking gun cost which is $\$ 6.55$ and the tube costs $\$ 7$.

$$
\text { Installation } \operatorname{Cost}(\$)=(\mathrm{NW} * 7)+6.55+(\mathrm{NW} * 0.25 * 15)[7.3]
$$

Where, $\mathrm{NW}=$ Number of Windows

4. Window Single Paned to Double Paned: The cost of double paned windows is optimized to $\$ 650$ which includes the labor, operation and profit costs as there different sizes and types of window frames available [17].

$$
\text { Installation } \operatorname{Cost}(\$)=\mathrm{NW} * 650[7.4]
$$

Where, $\mathrm{NW}=$ Number of Windows

5. Door Weather-Stripping: The cost of weather-stripping a door is obtained from [31] which is $\$ 17$ for a $7 \mathrm{ft} * 1$ inch strip. The cost includes labor cost which is $\$ 15 / \mathrm{hr}$ and weather-stripping each door takes approximately 1 labor hours.

$$
\text { Installation } \operatorname{Cost}(\$)=(\mathrm{ND} * 17)+(\mathrm{ND} * 15)[7.5]
$$

Where, ND $=$ Number of Doors

\section{- Lighting Savings}

1. For Fluorescent bulbs each fixture has different number of bulbs the cost of electronic ballast changes accordingly. For a fixture with 4 bulbs, electronic ballast costs $\$ 19$, for 3 bulb fixture costs $\$ 17.50$, for 2 bulb fixture costs $\$ 16$ and 1 bulb fixture costs $\$ 14$. Each T8 59Watt bulb costs $\$ 7$. The labor cost was estimated at $\$ 15 / \mathrm{hr}$ and it would take 
approximately 30 minutes to change the ballast and 5 minutes to fix a bulb. The T8 32 Watt bulb costs $\$ 2$, T8 28 Watt bulb costs $\$ 3.50$ and bulb costs $\$ 4.50$. For the T8 32 Watt to T8 28 Watt and T8 25 Watt options ballast cost is ignored. The cost data for all bulbs and ballast was taken from [32].

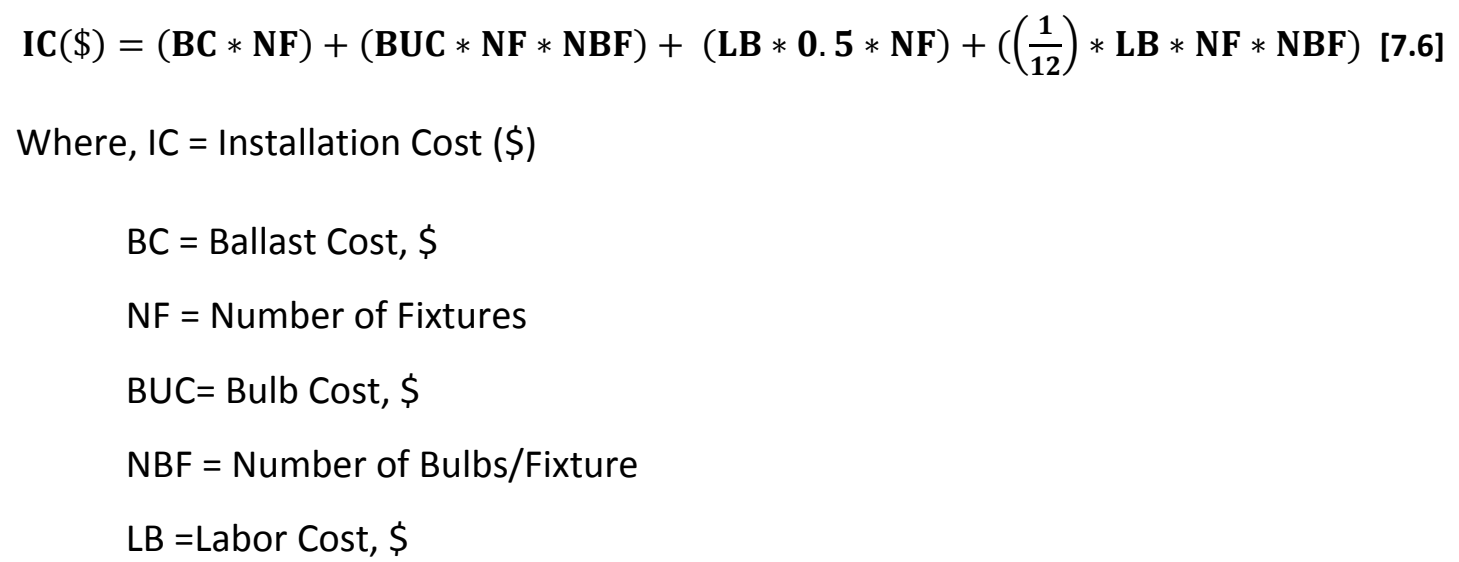

2. For High Intensity Discharge bulb options, each $\mathrm{MH} 360$ watts bulb costs $\$ 24.19$ [32] and the electronic ballast costs $\$ 100$ each [35], for the first option ballast cost is ignored, the formula used is given below.

$$
\text { Installation } \operatorname{Cost}(\$)=(\mathrm{BUC} * \mathrm{NB})+(\mathrm{LB} * \mathbf{0 . 5} * \mathrm{NB})+(\mathrm{BC} * \mathrm{NB})[7.7]
$$

Where, NB= Number of Bulbs

$$
\begin{aligned}
& \text { BUC = Bulb Cost }, \$ \\
& \mathrm{LB}=\text { Labor Cost } \$ \\
& \mathrm{BC}=\text { Ballast cost }, \$
\end{aligned}
$$

3. Lighting Levels Requirement: In this section as there are no light bulbs which are installed there is no installation cost. The excess bulbs are to be uninstalled. 
- HVAC Savings

1. Duct Insulation: In the Duct Insulation section the cost estimation was done using the Blanket type, fiberglass, flexible insulation [17]. The costs of R-3.5, R-5 and R-7 are taken and plotted on a graph with R-value on X-axis and cost on $\mathrm{Y}$-axis. According to the graph generated by MS-excel, there is an equation which is regressed from graph sheet and using this equation the installation cost is calculated.

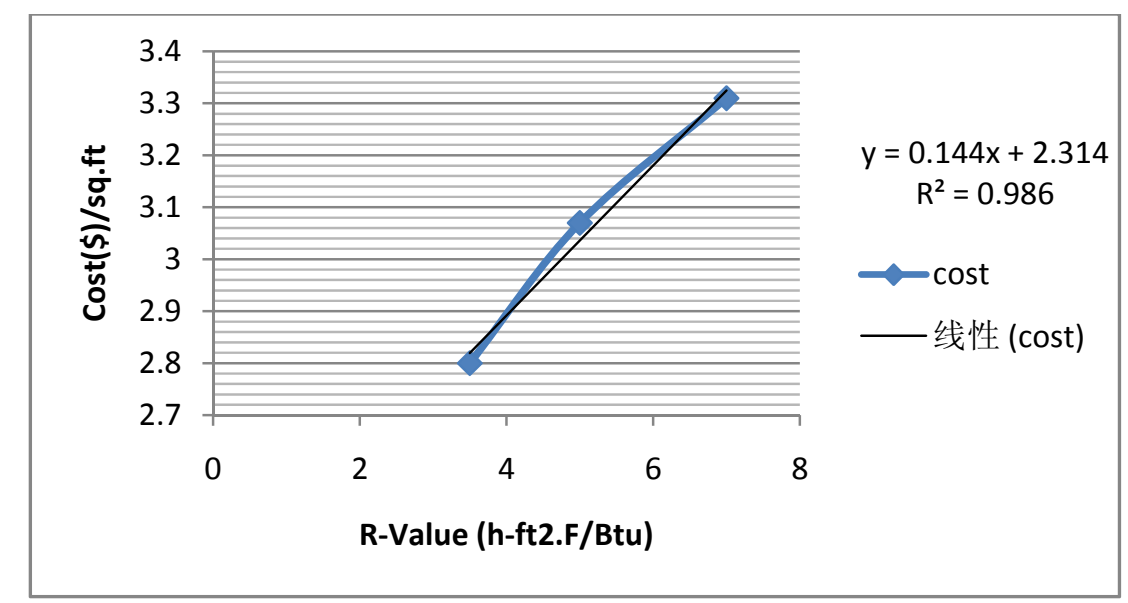

Figure 7.3 Duct Insulation R-value (h-ft2.F/Btu) vs. Cost (\$)

$$
\text { Installation } \operatorname{Cost}(\$)=((0.1443 *(\mathbf{R 2}-\mathbf{R} 1)+2.3143) * \text { DA [7.8] }
$$

Where, $R 2=$ Changed R-Value, h.ft ${ }^{2}$.F/Btu

$$
\begin{aligned}
& \mathrm{R} 1=\text { Present } \mathrm{R}-\text { Value, } h \cdot \mathrm{ft}^{2} . F / \text { Btu } \\
& \mathrm{DA}=\text { Duct Area, } \mathrm{ft}^{2}
\end{aligned}
$$

2. Cooling SEER: In Cooling Seer section the user may enter different ac unit size taking this into consideration, from [18] the cost of unit sizes 5, 7.5, 12.5, 18, 25 and 40 Tons packed single zone ac units were plotted in MS-Excel and the equation is obtained. 


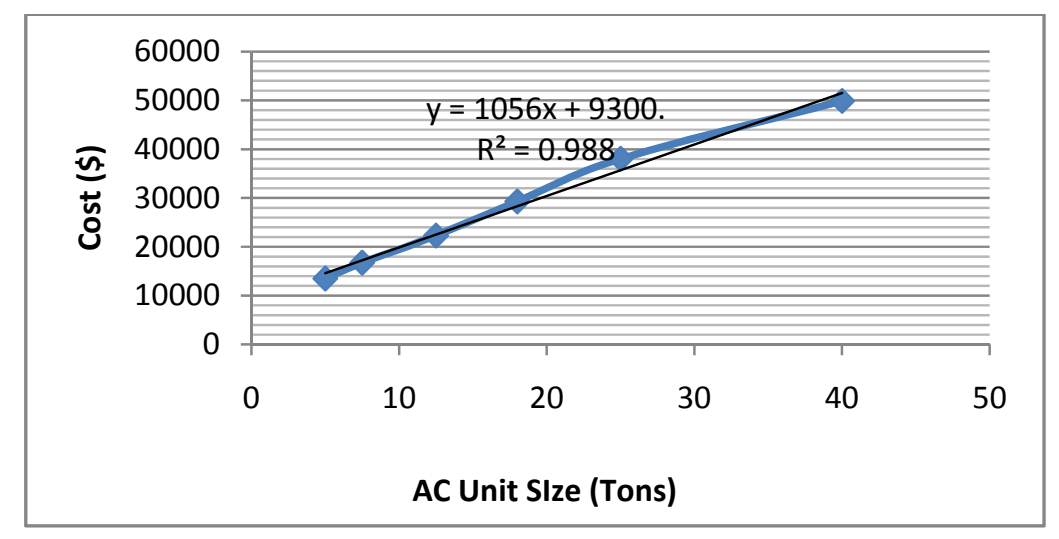

Figure 7.4 AC Unit Size (Tons) vs. Cost (\$)

$$
\text { Installation Cost }=(1056 * \mathrm{AC})+9300.7[7.9]
$$

Where, $\mathrm{AC}=\mathrm{AC}$ unit Size, Tons

3. Amount of Ventilation Air Needed: For this section there is a technician cost taken into account as the task requires a skilled technician and his fee would be on an average of $\$ 70 / \mathrm{hr}$ and since the task requires to be performed the whole day, the cost is $\$ 560 /$ day.

4. Shutoff Electric Reheat Systems: Since the electric reheat system is to be switched off for the summer time there is no installation cost or technician cost required.

5. Economizer: In this the cost of Economizer varies according to the size of the units. The cost of installing an economizer also includes labor cost. The labor cost is considered to be $\$ 400 /$ day as the job takes almost to be done. From [45] the cost of $10,20,25,40$ and 50 Tons unit are obtained and plotted on a graph. 


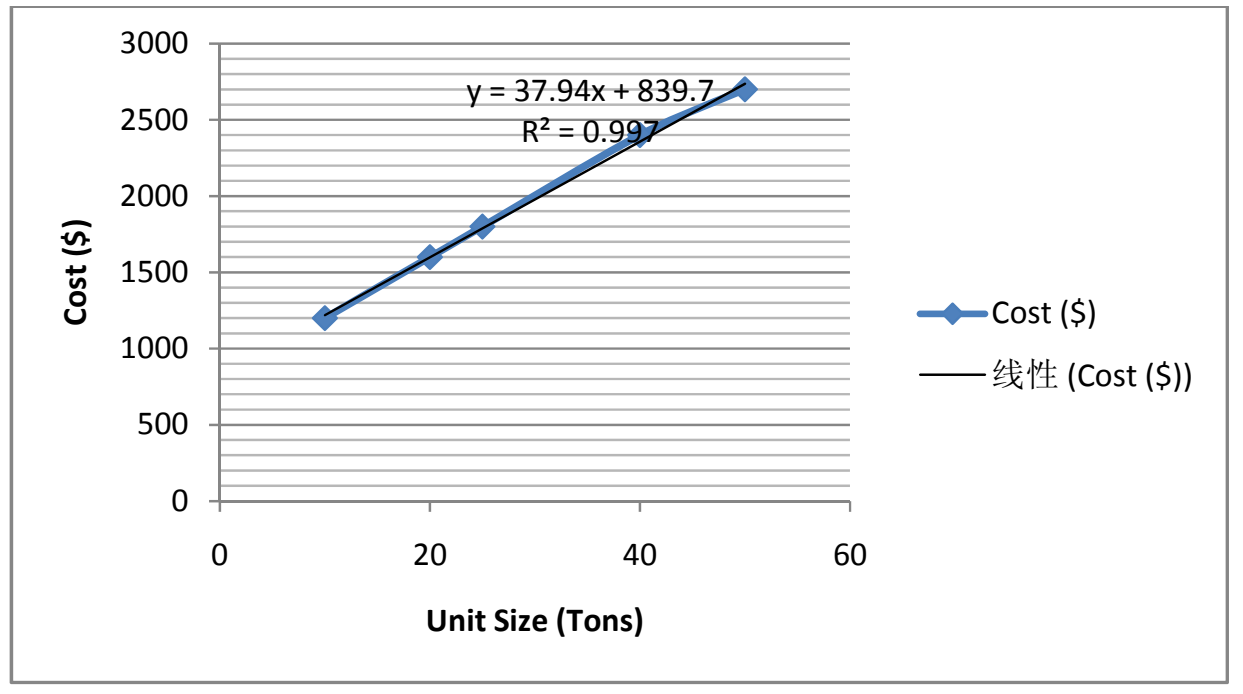

Figure 7.5 AC Unit Size (Tons) vs. Cost (\$)

$$
\text { Installation Cost }(\$)=(37.941 * \mathrm{AC})+839.71[7.10]
$$

Where $A C=A C$ unit Size, Tons

6. Staged Make-up Air Unit (MAU): The cost of Electric Make-up air unit is obtained from [34] and the unit sizes and costs are plotted on a graph and an equation for installation cost is obtained. The labor cost for these units are assumed to be same as the gas makeup air units [18].

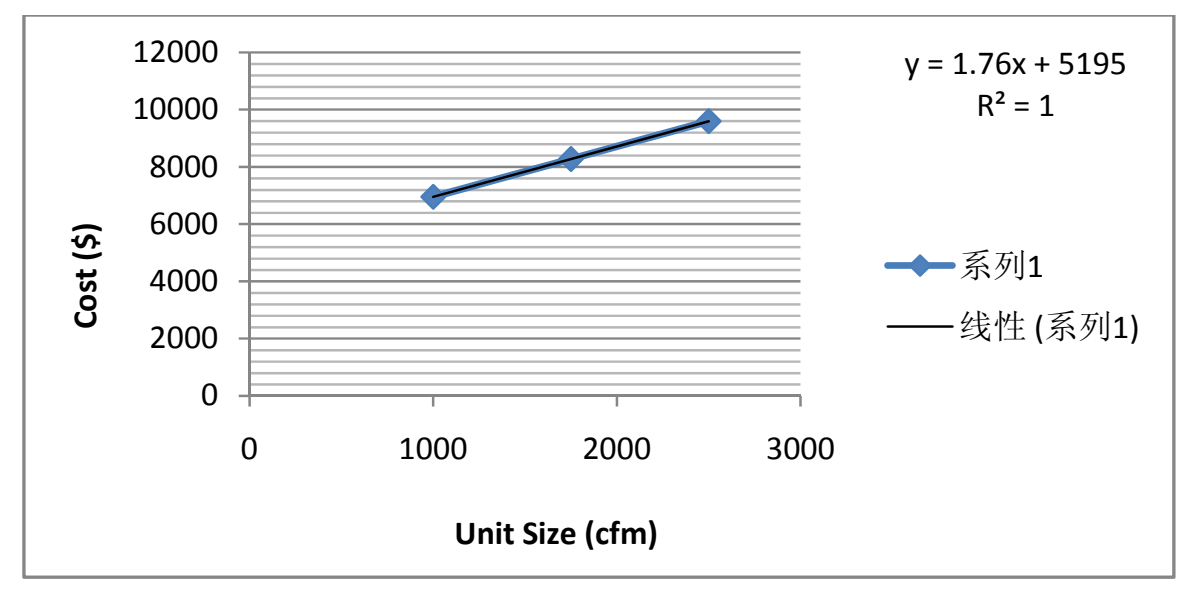

Figure 7.6 HVAC Unit Size (cfm) vs. Cost (\$) 


$$
\text { Installation Cost }=(1.76 * \text { US })+5195[7.11]
$$

Where, US = Unit Size, cfm

7. Setback Controls: The setback controls were assumed to be using a 2 time set back electric unit with a locking cover for each HVAC unit [18].

$$
\text { Installation } \operatorname{Cost}(\$)=\text { No. of HVAC units } * 250(\$)[7.12]
$$

8. HVAC Maintenance: This section consists of advising of different HVAC unit's maintenance, so there is no installation cost or other costs included.

- Service Water Heating Savings

1. Excess Oxygen Sensor: The Combustion analyzer cost was obtained from [36] and it is displayed directly as installation cost.

$$
\text { Installation } \operatorname{Cost}(\$)=\$ 1350[7.13]
$$

2. Heater Insulation: The graph for Heater Insulation is shown in the figure [5.8]. The $r-$ values chosen in the graph are $\mathrm{R}-5, \mathrm{R}-6.9$ and $\mathrm{R}-10$ [33]. The labor cost was assumed to be $\$ 15$ per hour. 


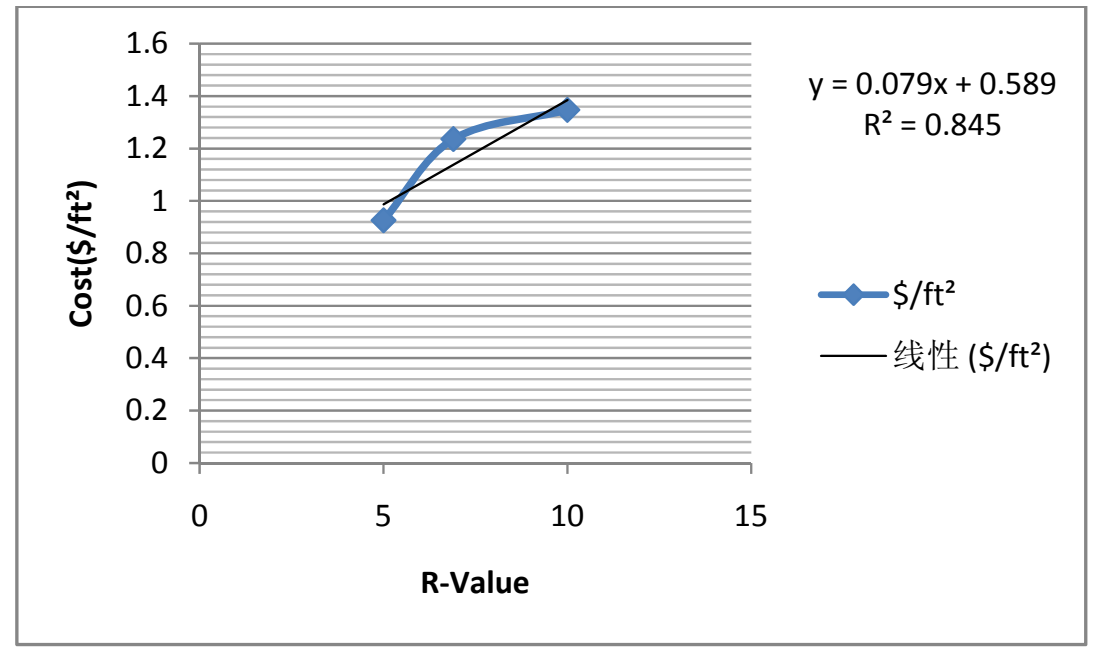

Figure 7.7 Heater Insulation R-value (h-ft2.F/Btu) vs. Cost $\left(\$ / \mathrm{ft}^{2}\right)$

$$
\text { Installation Cost }(\$)=((0.0795 *(\mathbf{R} 2-\mathbf{R} 1)+0.5895) * \mathrm{HA})+15[7.14]
$$

Where,

$$
\begin{aligned}
& \mathrm{R} 2=\text { Changed R-Value, } \mathrm{h} . \mathrm{ft}^{2} . \mathrm{F} / \text { Btu } \\
& \mathrm{R} 1=\text { Present R-Value, } \mathrm{h} \cdot \mathrm{ft}^{2} . \mathrm{F} / \text { Btu } \\
& \mathrm{HA}=\text { Heater Area, } \mathrm{ft}^{2}
\end{aligned}
$$

3. Instantaneous Heater: Since there are two types of Instantaneous or tankless gas heaters, the cost of heaters varies accordingly. The graphs showing the cost of both types of heaters which includes labor cost, Wiring and piping cost are shown in figures [5.8] [5.9] according to the sizes of the heaters. The equations for types of heaters are also given below. 


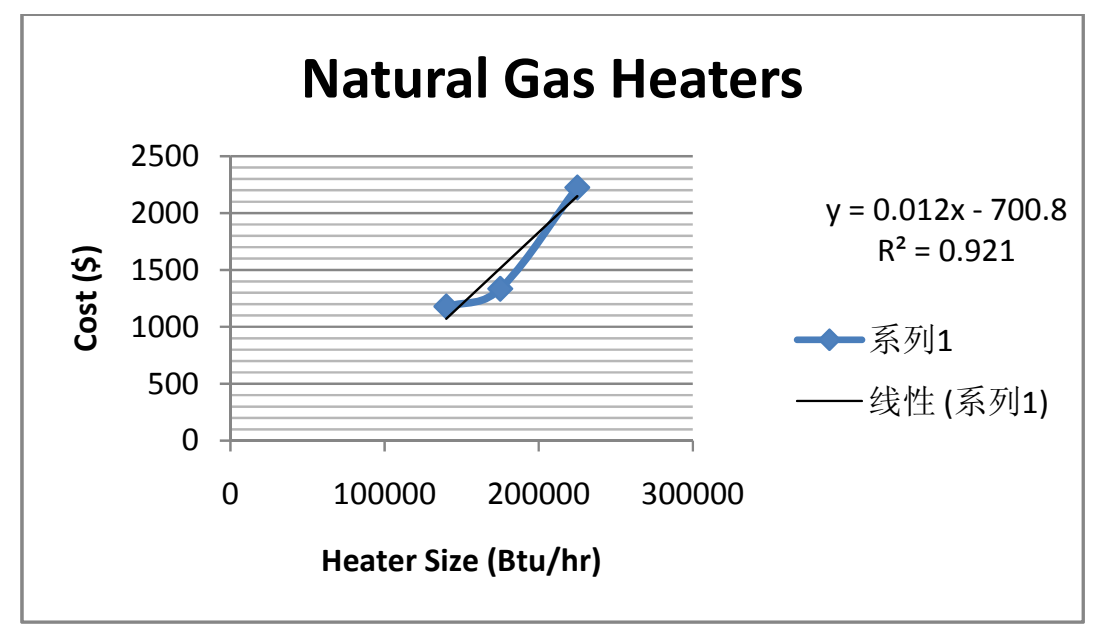

Figure 7.8 Heater Size (Btu/hr) vs. Cost (\$)

For Natural Gas, Installation $\operatorname{Cost}(\$)=(0.0127 *$ HS $)-700.8[7.15]$

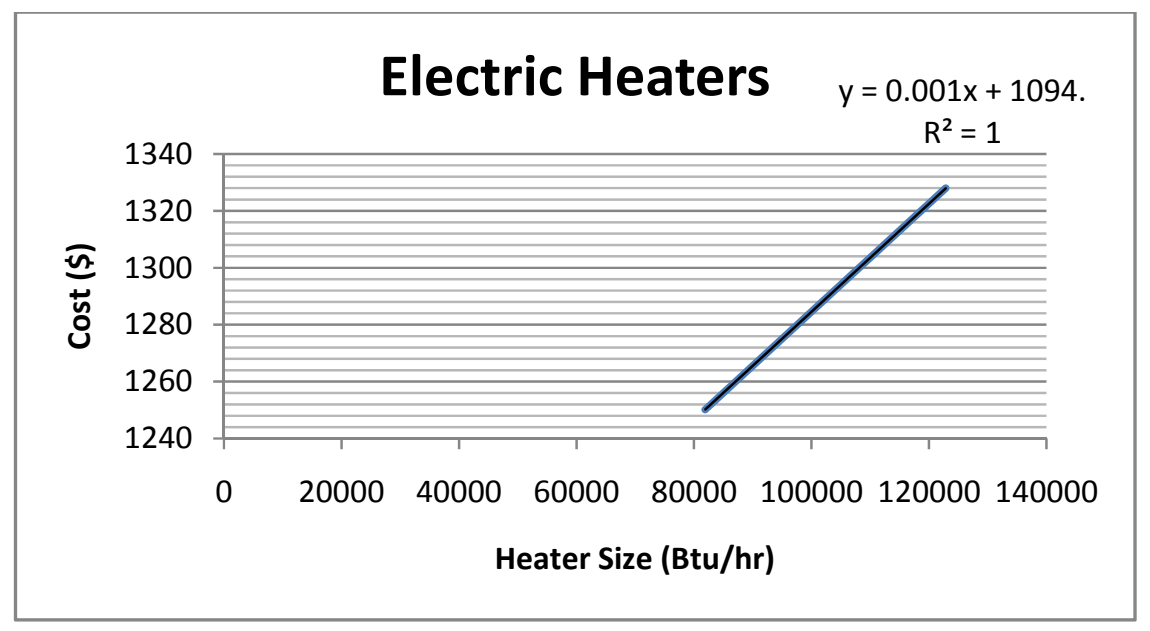

Figure 7.9 Heater Size (Btu/hr) vs. Cost (\$)

For Electric, Installation Cost $(\$)=(0.0019 *$ HS $)+941.58$ [7.16]

Where, HS = Heater Size, Btu/hr 
4. Water Heater Efficiency: The water heaters cost for different fuels was assumed to be more or less same as the gas heaters [18]. The graph was plotted for 30,50 and 80 gallons tanks and the equation of installation cost is obtained.

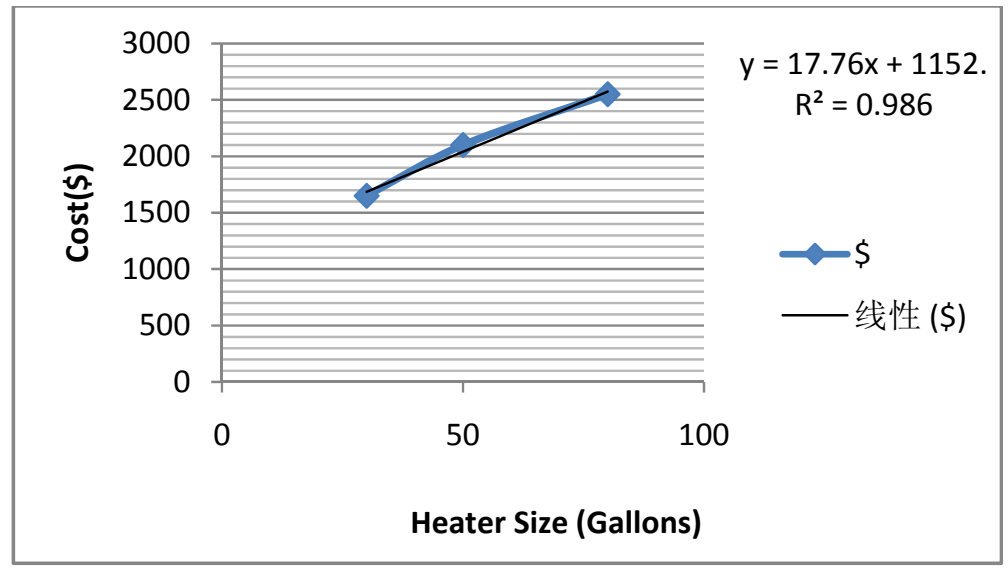

Figure 7.10 Heater Size (Gallons) vs. Cost (\$)

$$
\text { Installation } \operatorname{Cost}(\$)=(17.763 * \text { HS })+1152.6[7.17]
$$

Where, $\mathrm{HS}=$ Heater Size, gallons

5. Boiler Maintenance: The cleaning of the Boiler scales is a three day process and requires two cleaning personnel whose labor cost is approximately $\$ 70 /$ day. The total cost for cleaning is approximately $\$ 3360$.

\section{Cleaning Cost $(\$)=\mathbf{L C} * \mathrm{ND} * \mathrm{NL} * \operatorname{Hrs}[7.18]$}

Where, $\mathrm{LC}=$ Labor Cost, $\$$

ND $=$ Number of Days, 3

$\mathrm{NL}=$ Number of Labors, 2

Hrs = Labor Hours per day, 8 hrs/day 
6. Water Temperature: The Water Temperature can be adjusted to $120^{\circ} \mathrm{F}$ manually on a thermostat and there is no installation cost for this option.

7. Pipe Insulation: The Water Pipe Insulation is obtained from [42] and since the installing of insulation is an easier task and the school maintenance personnel can perform it easily, so the labor cost is excluded from the total cost of insulation.

$$
\text { Installation } \operatorname{Cost}(\$)=((2.66 * \mathbf{R})-\mathbf{0 . 8 0 6 7}) * \mathbf{L}[\text { [7.19] }
$$

Where, $\mathrm{R}=$ Insulation thickness, $\$ /$ Linear-ft

$L=$ Length of the Pipe, $\mathrm{ft}$

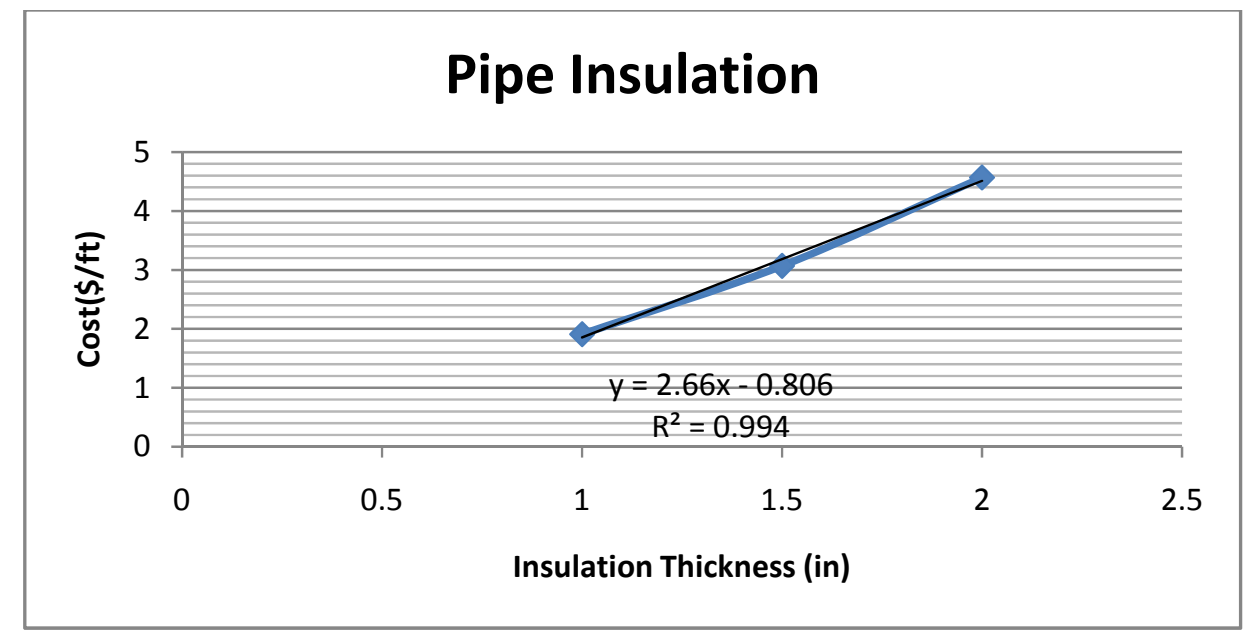

- Miscellaneous Savings

1. Computer Low Power Mode: Computer low power mode is the savings obtained by putting the computer in a hyper sleep mode. There is a message screen which is displayed about ENERGY STAR's EZ GPO \& EZ Wizard tool. 
2. Shower Heads: In this section the user can enter only 2.2 gallons per minute (gpm), 2 gpm, $1.75 \mathrm{gpm}, 1.5 \mathrm{gpm}, 1.25 \mathrm{gpm}$ and $1 \mathrm{gpm}$ in the changed shower head section. The cost of each shower head is $\$ 11, \$ 13, \$ 16, \$ 20$ and $\$ 25$ respectively [33]. Since the school maintenance personnel could do this job as a part of their daily routine work the labor cost is excluded for this option. The formula is given below.

\title{
Installation $\operatorname{Cost}(\$)=\mathrm{SHC} * \mathrm{NSH}[\mathrm{7.20]}$
}

Where, SHC $=$ Shower Head Cost \& NSH = Number of Shower Heads

3. Faucet (aerator): In this section the user can enter only 2.2 gallons per minute (gpm), $1.5 \mathrm{gpm}, 1 \mathrm{gpm}, 0.5 \mathrm{gpm}$ and $0.35 \mathrm{gpm}$ in the changed faucet head section. The cost of each shower head is $\$ 2.6, \$ 2.17, \$ 1.61$ and $\$ 1.6$ respectively. Since the school maintenance personnel could do this job as a part of their daily routine work the labor cost is excluded for this option. The formula is given below.

\author{
Installation $\operatorname{Cost}(\$)=$ FC $*$ NFH $[7.21]$ \\ Where, $\mathrm{FC}=$ Faucet (aerator) Cost $\& \mathrm{NFH}=$ Number of faucets
}

4. Pool Covers: The pool cover which was used is reinforced vinyl and it costs $\$ 1.08$ per sq.ft. [18]. The formula used is

$$
\text { Installation } \operatorname{Cost}(\$)=1.08 * \mathrm{PA}[7.22]
$$

Where, $\mathrm{PA}=$ Pool Area, $\mathrm{ft}^{2}$ 
5. Faucet Leakage: Since the leakages can be fixed by a plumber and most of the jobs would not take more than an hour, so the cost of plumber is considered as $\$ 52.05 /$ hour [18].

\section{Economic Analysis}

The payback period is determined for each saving choice and displayed as a result on the screen. The payback period is defined as the initial cost of investment divided by the annual cash inflows. The quotient is the number of years required for the schools to make the same amount of money required for the initial investment.

$$
\text { Payback Period }(\text { yrs })=\frac{\text { Cost for Installation }}{\text { Annual Cash Inflows }}[8.1]
$$

The cost of any installation is the total cost of the components and the labor cost. A few costs also include the installation and profits cost which are undertaken by a contractor. 


\section{Program Architecture}

This section describes the details about the composition of the code for the expert system software.

\subsection{Conditional Statement}

In the whole expert system there were a lot of conditional 'If' and 'else if' statements used in order to employ default values when the user is unsure of certain questions or the values needed for the formulae to give the final results according to the selections made. First, the selection of climate zone by the user, if a user selects climate zone 4 a then the default values for different recommendation types which are used in various calculations are Heating Degree Days (HDD) as 4987, Cooling Degree days (CDD) as 1288, Cooling Load (CLoad) as 1880.5 Btu.hr/lb-air and Heating Load (HLoad) as 8050 Btu.hr/lb-air and if the user selects climate zone 5a then the default values are Heating Degree Days (HDD) as 5522, Cooling Degree days (CDD) as 985, Cooling Load (CLoad) as 2925.4 Btu.hr/lb-air and Heating Load (HLoad) as $8700 \mathrm{Btu} . \mathrm{hr} / \mathrm{lb}$-air. The figure below shows the logic used to determine the default values taken into consideration for the calculations.

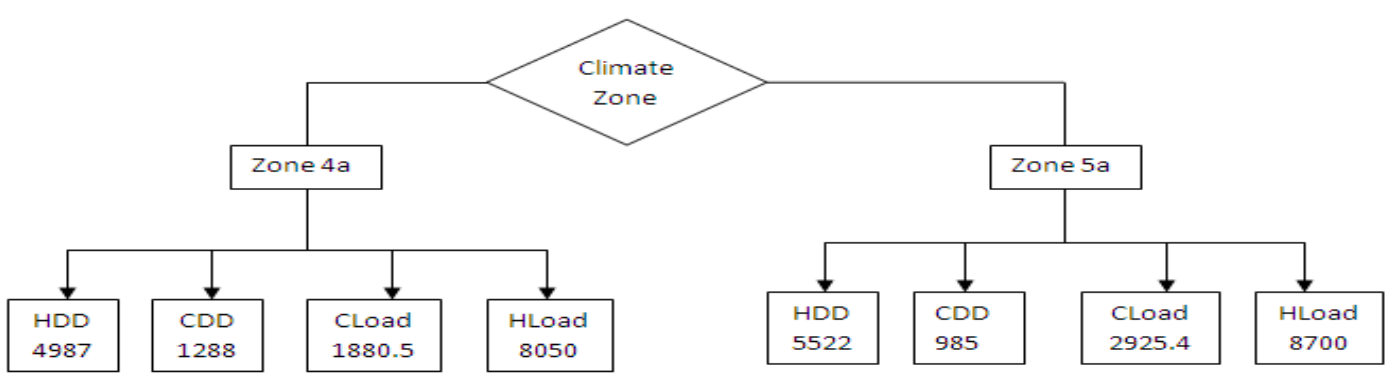

Figure 9.1 Flow chart for default values upon selecting climate zone 
Second, the selection of fuel type which performs two functions, for calculations assigning the default value heating value for each of the fuel selected and the other is asking the user the amount they pay per unit of a fuel. There are four fuel types chosen Natural gas, Propane, Fuel Oil and Electric and the heating values are $1050 \mathrm{Btu} / \mathrm{cu} . \mathrm{ft}, 90,000 \mathrm{Btu} / \mathrm{gallon}, 140,000$ Btu/gallon and $3413 \mathrm{Btu} / \mathrm{KWh}$ respectively. If the user selects yes for the amount they pay per unit of fuel then a box appears to enter the amount else the default value appears on the screen which \$10.31/MCF for natural gas, \$2.65/gallon for propane, \$2.6/gallon for fuel oil and $\$ 0.07 / \mathrm{KWh}$ for electric. The figure below shows the logic for the fuel selection.

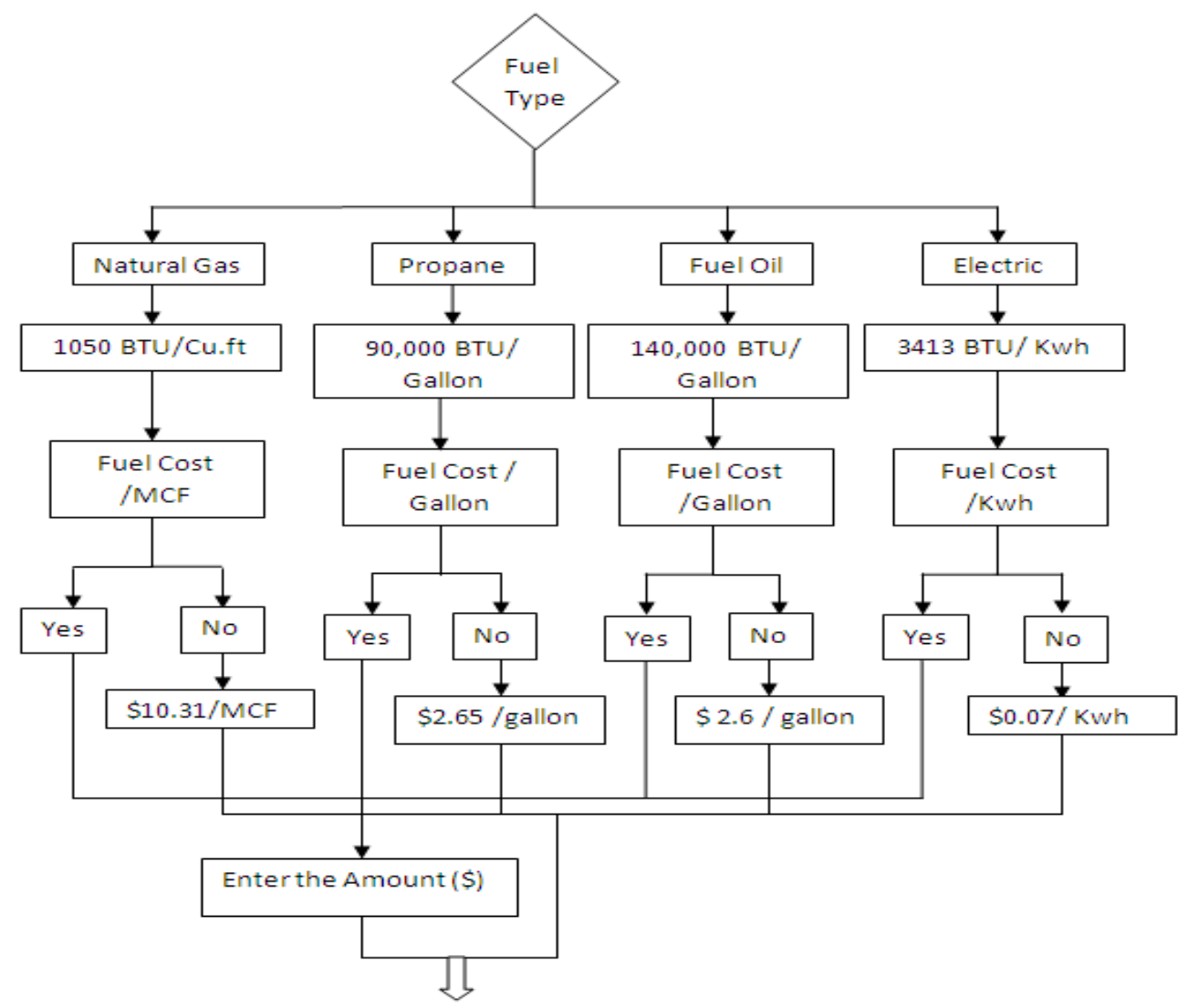

Figure 9.2 Flow Chart for logic of Fuel Selection 
Third, there are different sub-conditional statements used for different options for window caulking there are extra two options, one is 'Floor where the windows/window is' and the other is 'Window Type'. 'Floor where the windows/window is' contains ground floor, 1 st floor and $2^{\text {nd }}$ floor and 'Window Type' contains Single paned and Double paned. By selecting these buttons there are default values $\mathrm{Cs}$ and $\mathrm{Cw}$ which stand for stack co-efficient and wind co-efficient respectively and $U$-values for single and double paned are assigned to the parameters for the calculations. The figure below shows the logic for the above options.

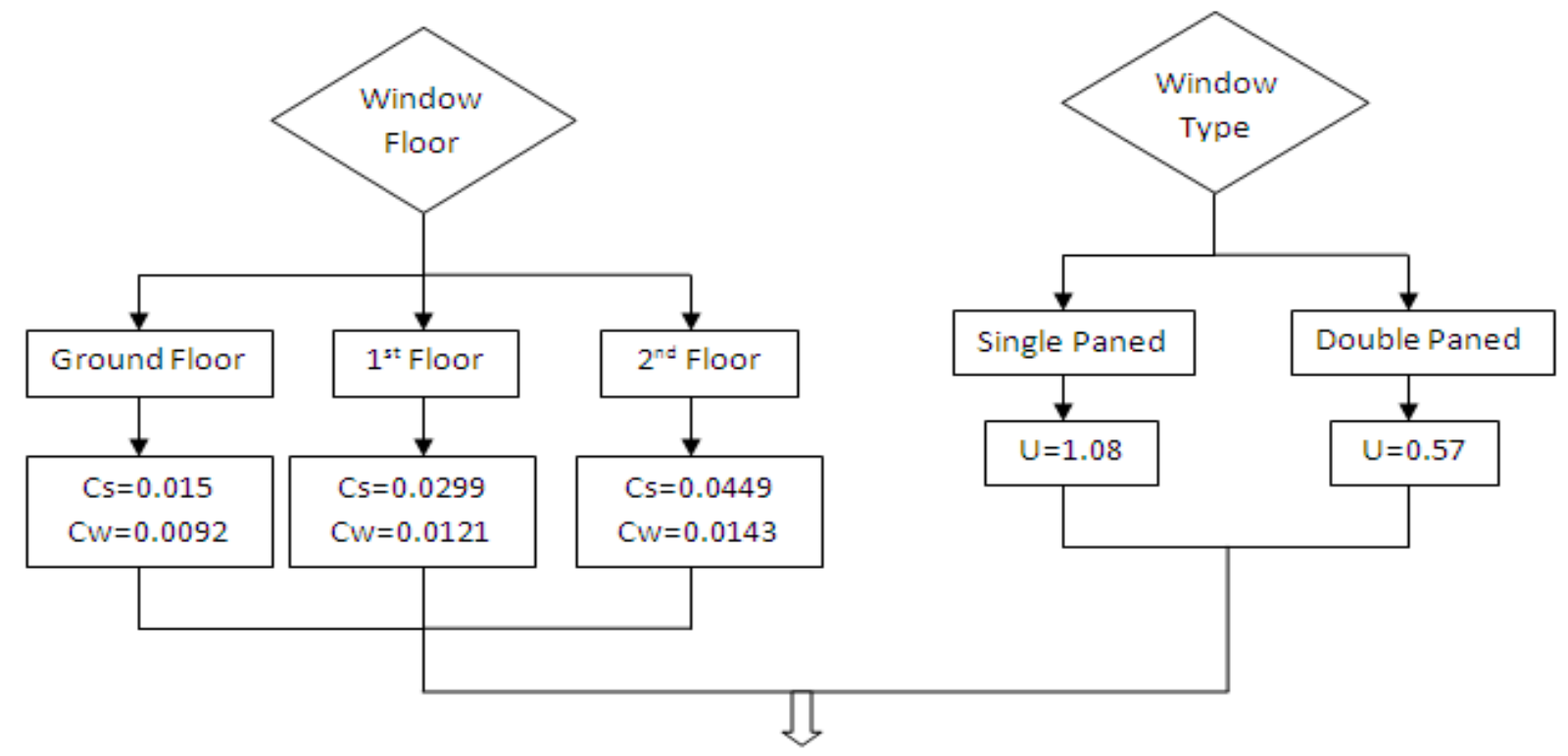

Figure 9.3 Flow chart showing logic for window Floor and type

In Duct Insulation option there is an option for duct types, there are Circular Duct and Square/Rectangular Duct, by clicking circular duct the duct diameter $(\mathrm{ft})$ and duct length (ft) boxes appear where the user has to input and by clicking Square/Rectangular Duct the duct 
width (ft), duct depth (ft) and duct length (ft) appear where the user has to input the data. The figure below shows the logic for the above options.
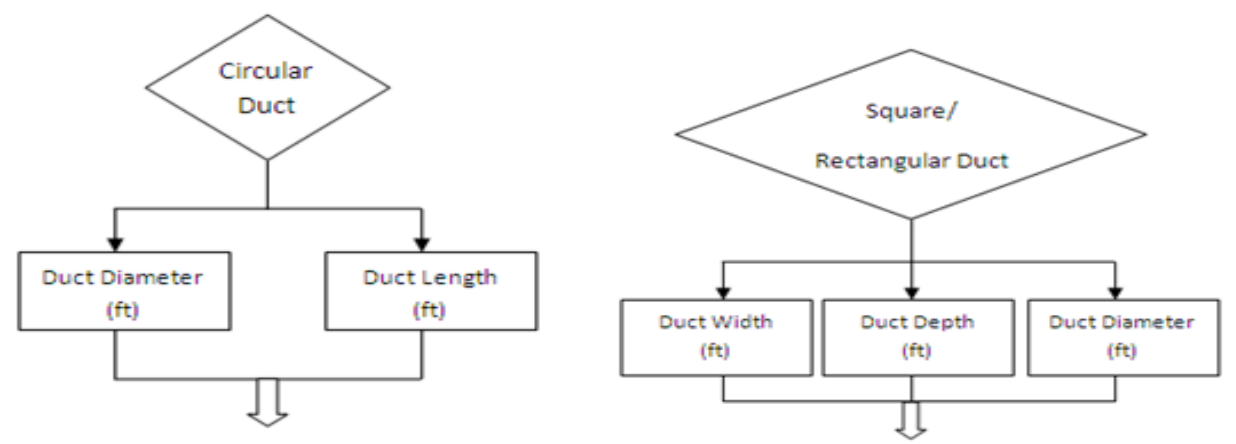

Figure 9.4 Flow Chart showing logic for Duct types

In 'Amount of ventilation air Needed', 'Shutoff Electric Reheat Systems' and 'Computer Low Power Mode' options, there are conditional statements which pop out messages. The figure below shows the logic for the above options.

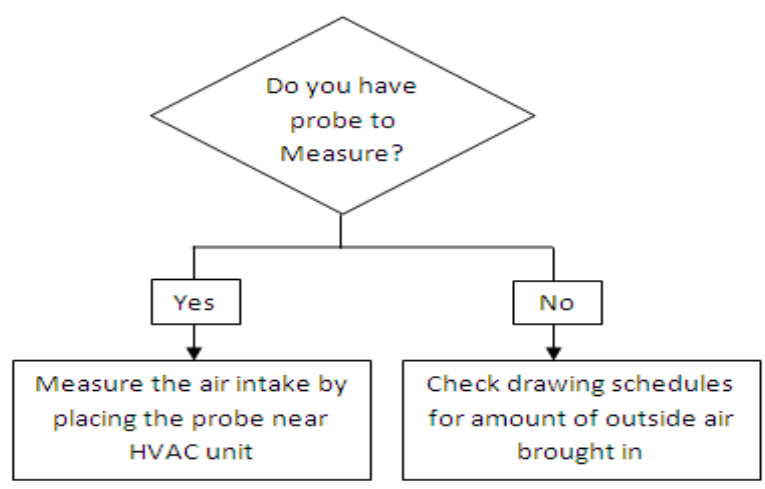

Figure 9.5 Flow chart Logic for Measuring Probe 


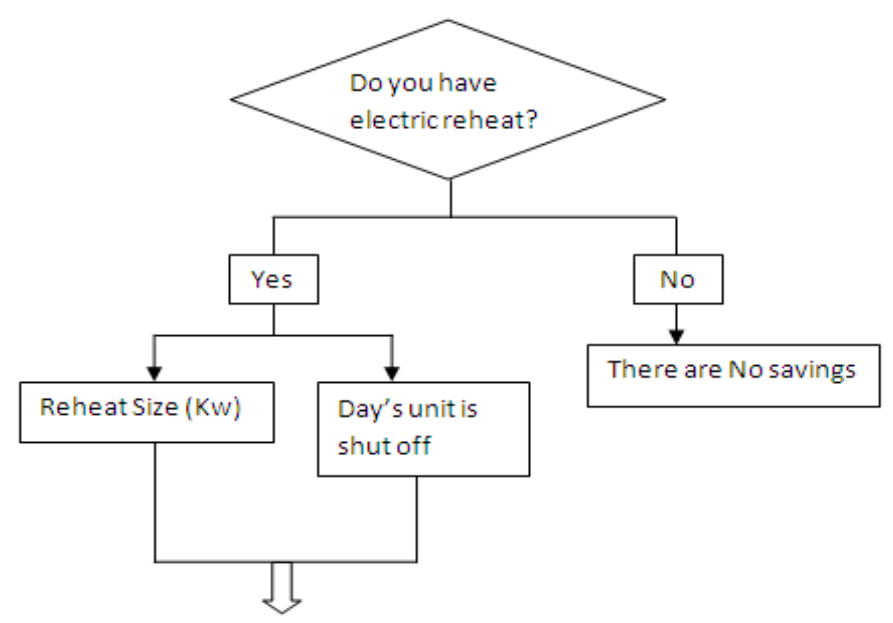

Figure 9.6 Flow chart showing logic for Electric reheat

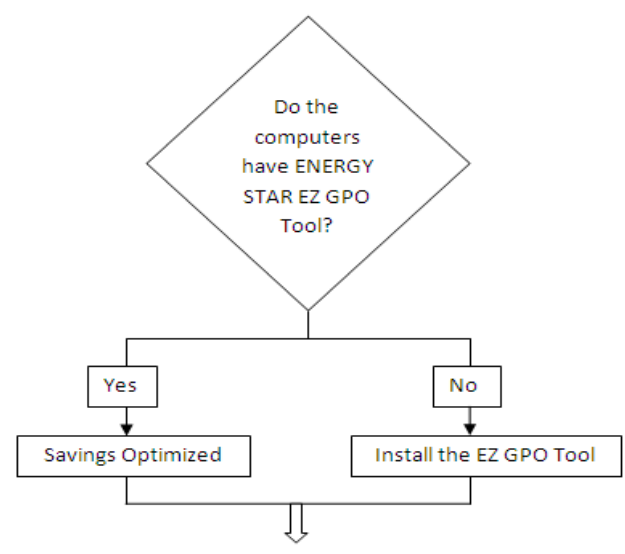

Figure 9.7 Flow chart showing logic for ENERGY STAR EZ GPO Tool

Fourth and the main conditional statements used were for the main savings type and also the option which appear when clicking the savings type. There is also a 'Go to main menu' button in each of the energy saving option which brings back to energy saving buttons again. 


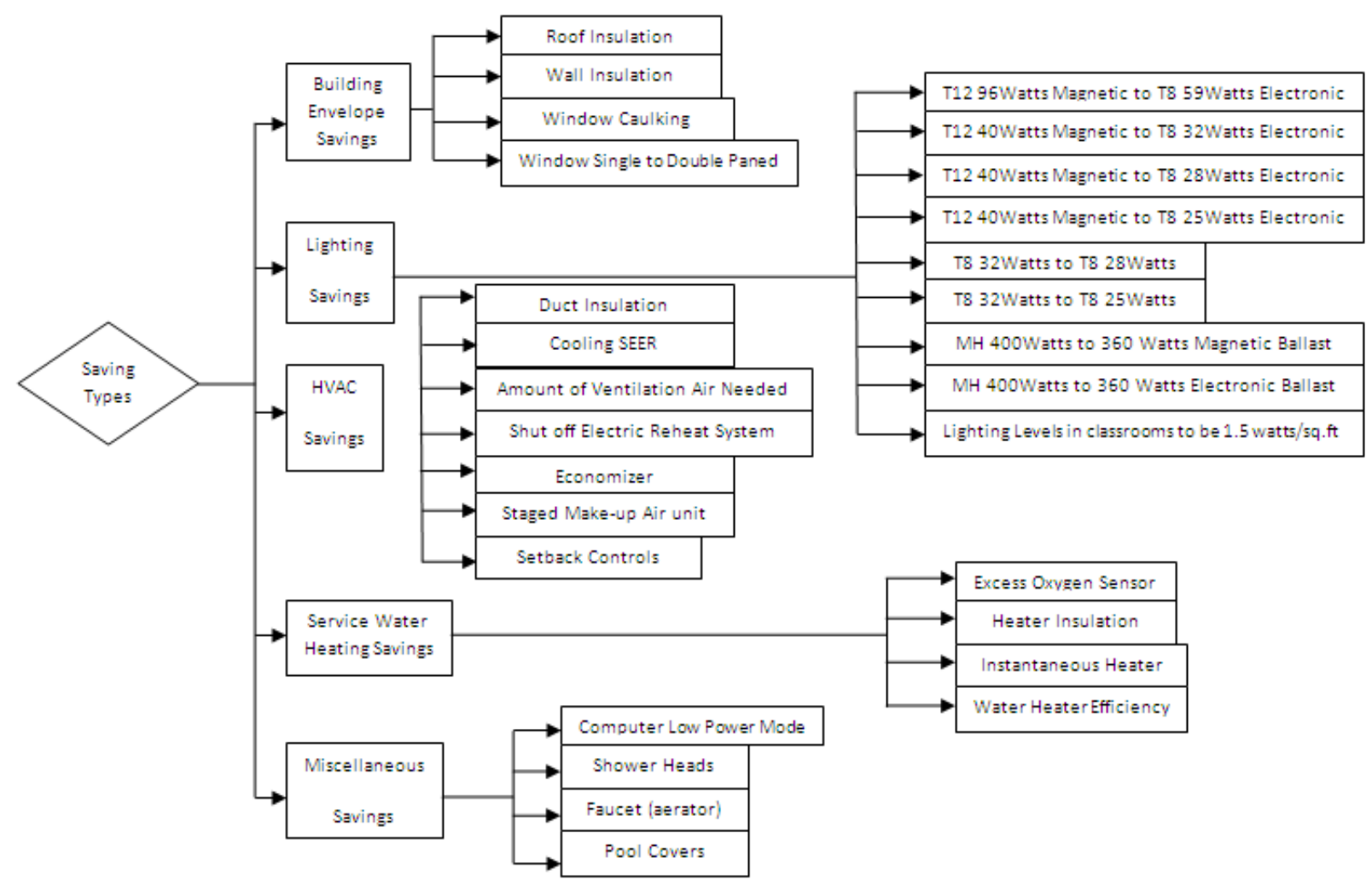

Figure 9.8 Logic for the whole expert system

\subsection{User Interface}

The introduction screen of the expert system has the list of counties which are in climate zone $4 a$ and $5 a$ and there is an important note which has a message saying please remember your climate zone as it is useful for future calculations and there is a start button, upon clicking it the saving types screen appears. The two figures are shown below. 


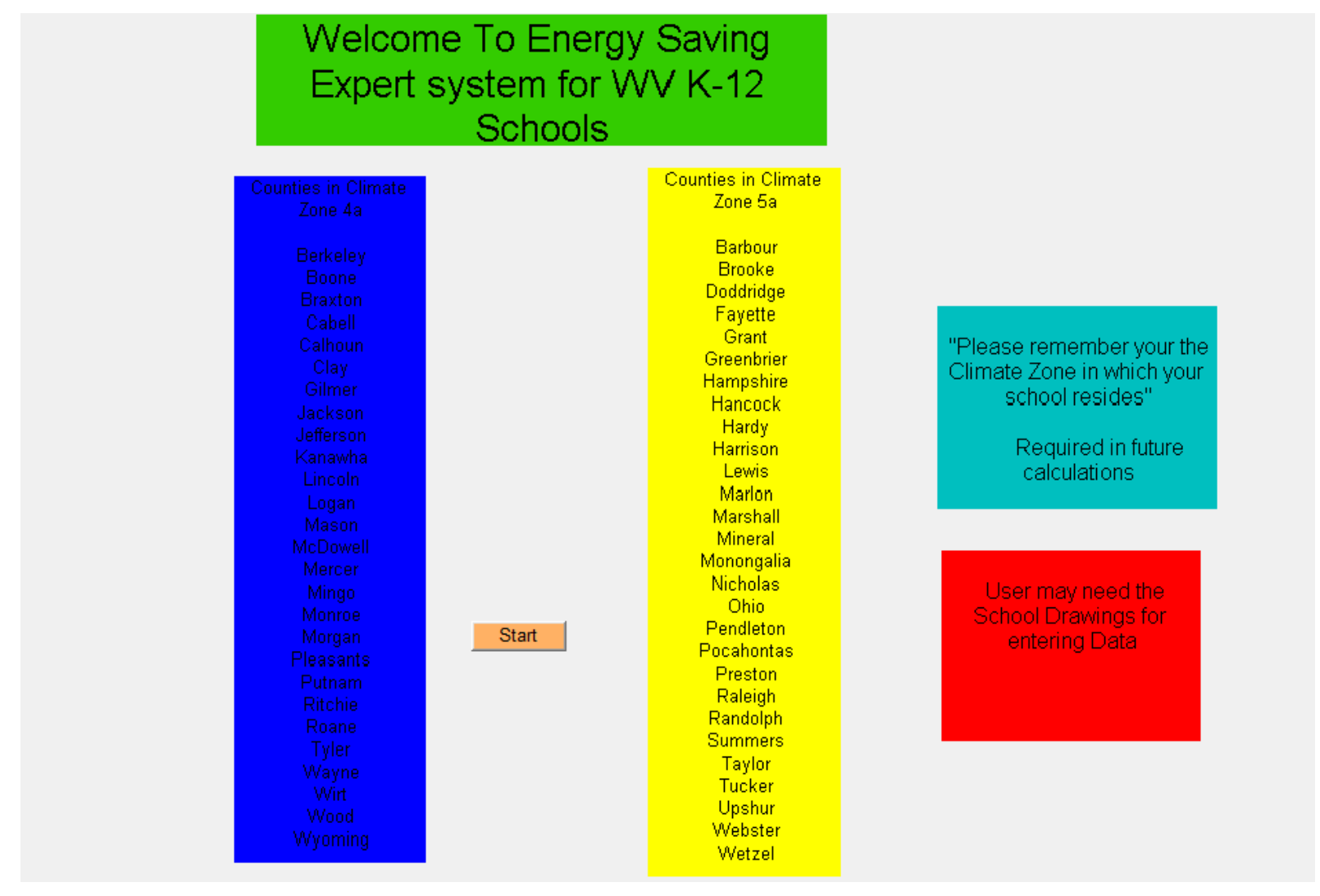

Figure 9.9 Introduction Screen of Expert system

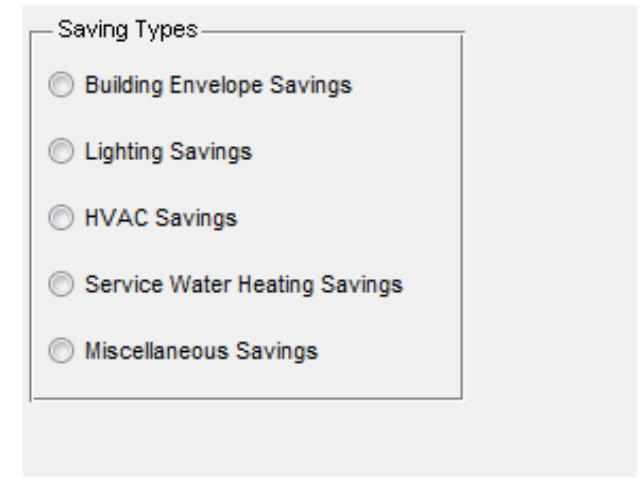

Figure 9.10 Screen for saving types

For example, upon clicking any of the saving type's buttons the respective information regarding the savings type is displayed to the right and below is the option screen. Below is the figure which shows the screen and the options when building envelope savings button is clicked. 


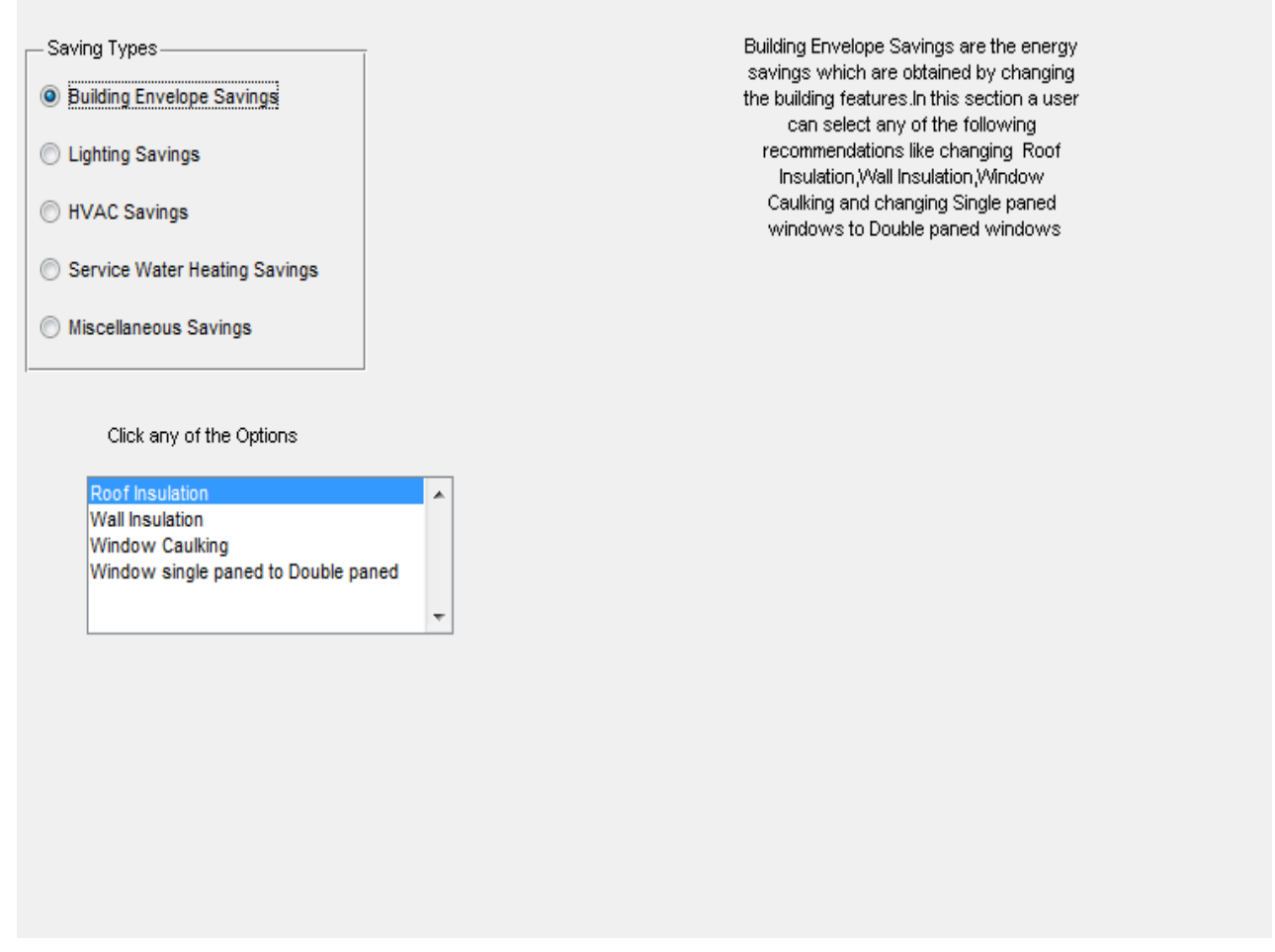

Figure 9.11 Screen showing the selection of Building Envelope Savings

By clicking the Roof insulation the screen which consists of all questions pop's up. The user selects the Roof Type, upon selecting one of the two, the types of roofs with different materials show up, upon selecting one a default value appears in the present R-Value box. In the screen you can notice by clicking the Natural gas as fuel option the question 'Do you know how much you pay per MCF of Natural Gas?' appears and by clicking 'No' option the default value of Fuel cost appears $\$ 10.00 / \mathrm{MCF}$. There is a Back to Main menu pushbutton at the bottom right corner of the screen. Below is the Figure [6.12] which shows the options. 


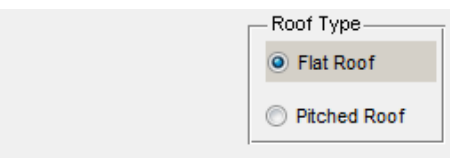

Enter the Present R-Value of the roof Insulation(h.ft2.F/Btu)

Enter the changed R-Value of the Roof Insulation (h.ft2.F/Btu)

Enter the Efficiency of the HVAC system(\%)

Enter the Roof Area $\left(\mathrm{ft}^{\wedge} 2\right)$

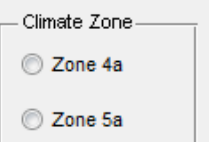

Do vou Know How much vou pav per Mct of Natural Gas?

\section{Savings}

Energy Saved with New Roof Insulation

Money saved with New Roof Insulation(\$)

Cost for Installing New root(\$)
1. Built-up Roof, Air film, Acoustic Tile

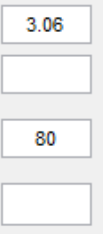

New Unit $\quad-$

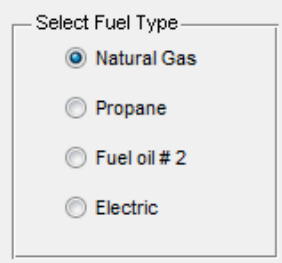

Yes

(2) $\mathrm{No}$

Fuel Cost

$\$ 10.00 \mathrm{MCF}$

Back to Main Menu

Figure 9.12 Screen showing the questions for Roof Insulation

There are some extra features added to the system for each and every energy saving option, for example, if the user enters the unknown characters or the number which is invalid then the error dialogue message appears saying 'Enter only numbers' or 'Value should be than 1 ' and if the user enters less than $100 \%$ for electric heaters then upon clicking electric heaters a warning message appears saying 'Electric heaters are $100 \%$ efficient'. The figures of the all the above mentioned things are given below. 


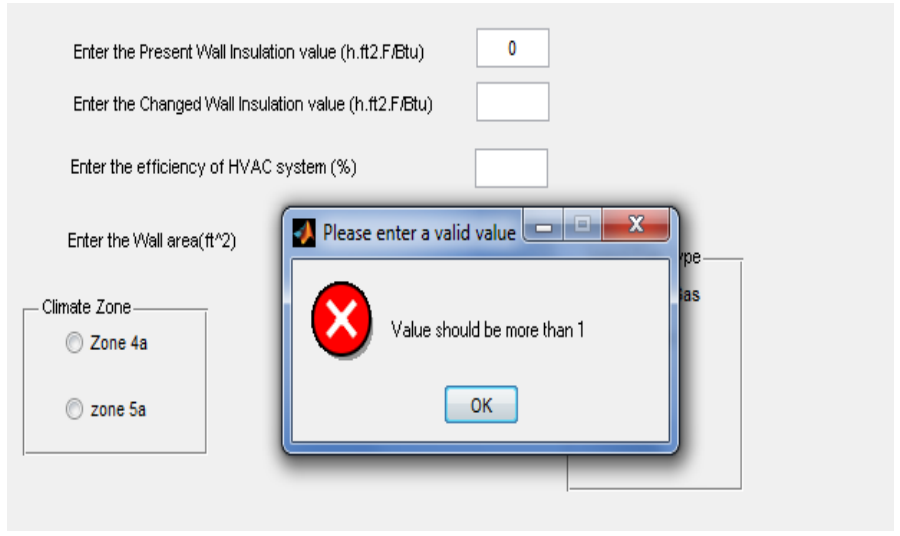

Figure 9.13 The error dialogue showing value to be more than 1

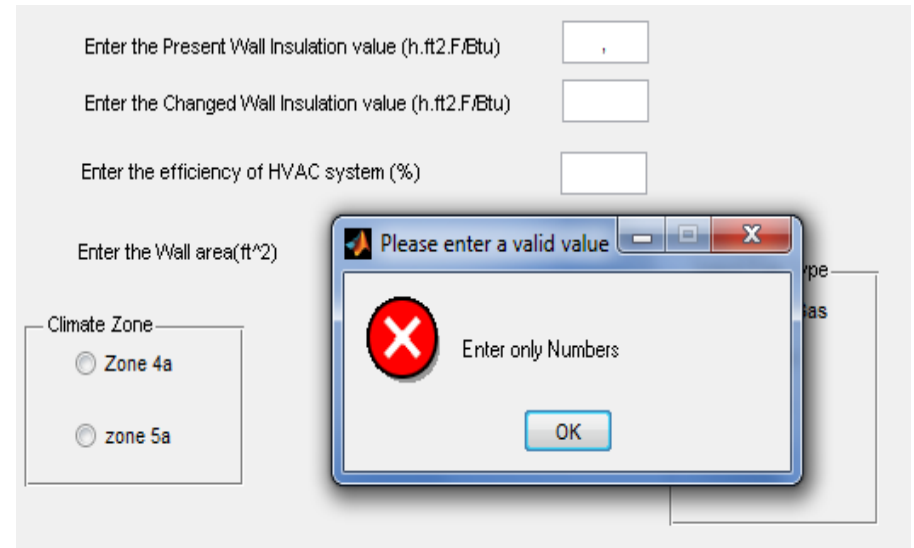

Figure 9.14 The error dialogue showing enter only numbers

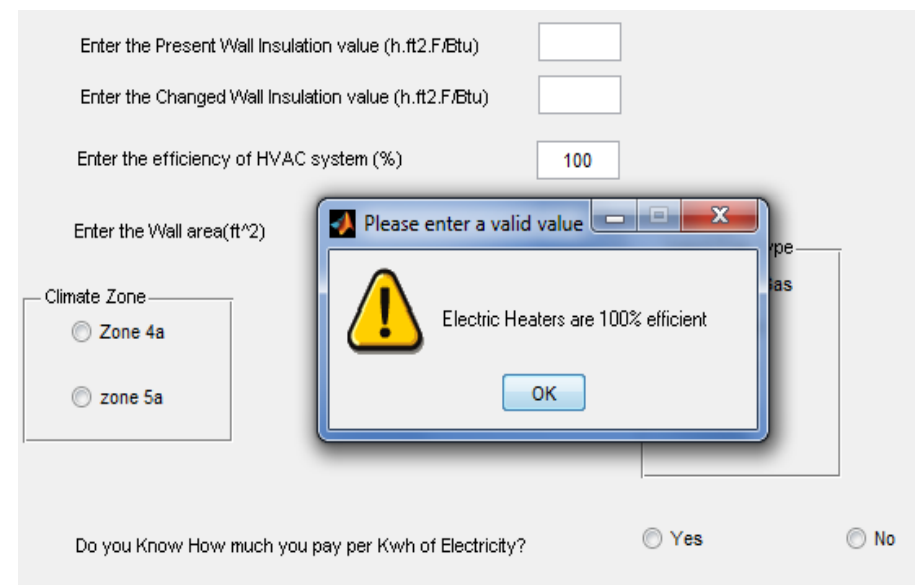

Figure 9.15 Warning Dialogue showing electric heaters are $100 \%$ efficient 


\section{Results and Verification:}

In order to determine the ability and uncertainty of the program to output useful and reliable data, the work done by others are entered into the expert system. This section shows the input values which were entered into the system and output values that were obtained to check the difference in results.

\subsection{Test case 1}

First Test case is the changing of Wall insulation of a two-story single-family home which was simulated in two climatic zones using eQuest software [40]. The two climate zones mentioned in [40] are Detroit, MI and Miami, Fl and the details about the R-Value, Wall Area, Efficiency of HVAC unit, HDD, Heat saved (Btu/hr), temperature difference and fuel cost taken into consideration by WVU are given in the table [10.1]. The climate zone $5 \mathrm{a}$ is used for the calculations as Detroit lies in zone 5 a.

Table 10.1 Attributes and Values

\begin{tabular}{|c|c|}
\hline Attributes & Values \\
\hline R-Value & 19 \\
\hline Added R-Value & 30 \\
\hline Roof Area & $1910 \mathrm{ft}^{2}$ \\
\hline Efficiency & $95 \%$ \\
\hline Climate Zone & $5 \mathrm{a}$ \\
\hline Fuel Type & Electric \\
\hline
\end{tabular}

The Values entered and options selected in the expert system are given in the table [10.2]. 
Table 10.2 Questions and Input data

\begin{tabular}{|c|c|}
\hline Question? & Inputs \\
\hline Present R-Value & 19 \\
\hline Changed R-Value & 30 \\
\hline Efficiency & $95 \%$ \\
\hline Roof Area & $1910 \mathrm{ft}^{2}$ \\
\hline Climate Zone & $5 a$ \\
\hline Fuel Type & Electric \\
\hline Fuel Cost $\mathbf{\$} / \mathrm{kWh})$ & $\$ 0.07$ \\
\hline
\end{tabular}

The results obtained by [40] and Expert system and also the percentage variation in results are given in the table [10.3].

Table 10.3 Results and \% Difference

\begin{tabular}{|c|c|c|c|}
\hline Results & {$[40]$} & Expert System & Diff (\%) \\
\hline Energy Saved (kWh) & 1500 & 1506.60 & 0.40 \\
\hline Money Saved (\$) & $\mathrm{n} / \mathrm{a}$ & 105.46 & $\mathrm{n} / \mathrm{a}$ \\
\hline Installation Cost (\$) & $\mathrm{n} / \mathrm{a}$ & 3470.45 & $\mathrm{n} / \mathrm{a}$ \\
\hline Payback Period (yrs) & $\mathrm{n} / \mathrm{a}$ & 34.80 & $\mathrm{n} / \mathrm{a}$ \\
\hline
\end{tabular}

\subsection{Test Case 2}

A 300 room hotel has 290 T12 40Watt which are converted into T8 25Watt bulbs [41] and the details of the attributes plugged-in by the hotel and expert system are provided in the table [10.4]. 
Table 10.4 Attributes and values

\begin{tabular}{|c|c|c|}
\hline Attributes & {$[41]$} & Expert System \\
\hline Number of Fixtures & 145 & 145 \\
\hline Bulbs/fixture & 2 & 2 \\
\hline Hours bulbs are ON per year & $18^{*} 365$ & 6570 \\
\hline Fuel Cost(\$/kWh) & 0.12 & 0.12 \\
\hline
\end{tabular}

Table 10.5 Results and \% Difference

\begin{tabular}{|c|c|c|c|}
\hline Results & {$[41]$} & $\begin{array}{c}\text { Expert } \\
\text { System }\end{array}$ & Diff (\%) \\
\hline Energy Saved (kWh/yr) & 30,484 & 30,484 & 0.0 \\
\hline Money Saved (\$) & 3658 & 3658 & 0.0 \\
\hline Installation Cost (\$) & 4132.5 & 5075 & 18.5 \\
\hline Payback Period (yrs) & 2.3 & 1.4 & 39 \\
\hline
\end{tabular}

The difference in the Installation cost is because, the cost in the hotel per one bulb and half of the electronic ballast costs $\$ 14.25$ including labor and the cost in the expert system was taken as, per ballast $\$ 16$ and per bulb $\$ 4.50$. For the labor costs the ballast and bulb replacement time is required, so the time required to change was assumed for a ballast to be half-an hour and each bulb to be 5 minutes, and according to the user input of number of bulbs and fixtures the labor cost is obtained.

\subsection{Test Case 3}

In this case, a live case of lighting levels in Mineral Resource Building (MRB) room 107 of WVU is studied as the test case. The details of manual calculations and those entered into the expert system are provided in table [10.6] and results in table [10.7]. The lighting levels 
of the room are measured using a light meter and the reading was $120 \mathrm{fc}$ and also the wattage per $\mathrm{ft}^{2}$ was 2.1 where as ASHRAE 90.1 recommends lighting level of $1.4 \mathrm{Watt} / \mathrm{ft}^{2}$.

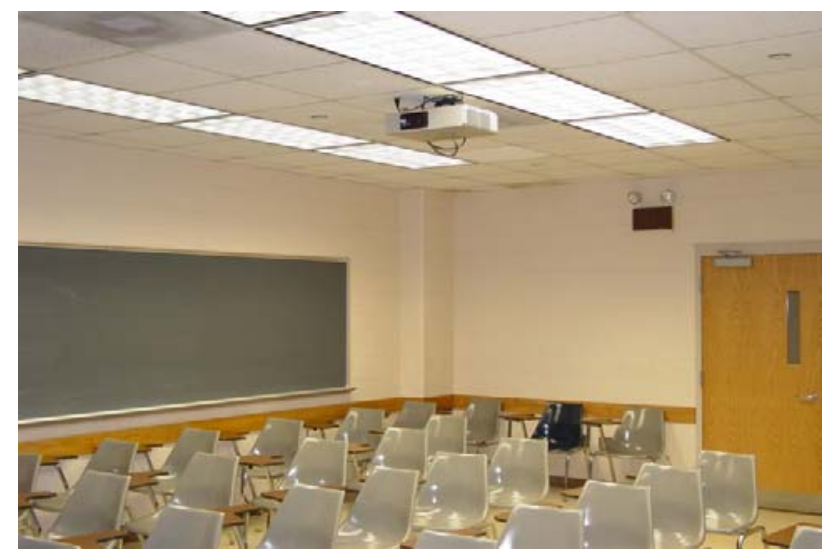

Figure 10.1 Lighting in MRB \# 107

Table 10.6 Attributes and Values

\begin{tabular}{|c|c|c|}
\hline Attributes & $\begin{array}{c}\text { Manual } \\
\text { Calculations }\end{array}$ & $\begin{array}{c}\text { Expert } \\
\text { System }\end{array}$ \\
\hline Room Width (ft) & 19.5 & 19.5 \\
\hline Room Length (ft) & 24.6 & 24.6 \\
\hline Bulb Wattage (W) & 28 & 28 \\
\hline \# Fixtures & 12 & 12 \\
\hline \# Bulbs/Fixture & 3 & 3 \\
\hline
\end{tabular}

Table 10.7 Results and \% Difference

\begin{tabular}{|c|c|c|c|}
\hline Results & $\begin{array}{c}\text { Manual } \\
\text { Calculations }\end{array}$ & Expert System & Diff (\%) \\
\hline Energy Saved (Watt/ $\mathrm{ft}^{2}$ ) & 1.4 & 1.4 & 0 \\
\hline Extra Lighting Levels (Watt/ $\mathrm{ft}^{2}$ ) & 0.7 & 0.7 & 0 \\
\hline \# Lights need to be Uninstalled & 12 & 12 & 0 \\
\hline
\end{tabular}

\subsection{Test Case 4}

In this case, an indoor swimming pool in Eastern Leisure center, Cardiff, UK [44] uses a pool cover 8 hours every night throughout the year by doing so the centre has saved 
energy and money. The savings of the report [44] are provided based on four operation regimes based on pool cover, Heating water and Ventilation Conditions. Since the expert system has a section which asks the user to input the "Hours the pool is heated but not covered?" taking this into consideration, the savings obtained by operating regime 3 is considered for the test case. The details of attributes and values of [44] and expert system are provided in table [10.8] and results in [10.9].

Table 10.8 Attributes and Values

\begin{tabular}{|c|c|c|}
\hline Attributes & {$[44]$} & Expert System \\
\hline Pool Area $\left(\mathrm{ft}^{2}\right)$ & 3364 & 3364 \\
\hline & Gas Fired Combined -Heat and & 70 \\
Boiler Efficiency (\%) & Power (CHP) & 2920 \\
\hline Bulb Wattage (W) & $8^{*} 365$ & Natural Gas \\
\hline Fuel Type & Natural Gas & \\
\hline
\end{tabular}

Table 10.9 Results and \% Difference

\begin{tabular}{|c|c|c|c|}
\hline Results & {$[44]$} & Expert System & Diff (\%) \\
\hline Energy Saved & $305,000 \mathrm{kWh} / \mathrm{yr}$ & $952,488 \mathrm{cu} . \mathrm{ft} / \mathrm{yr}$ & 3.92 \\
\hline Money Saved (\$) & $\mathrm{n} / \mathrm{a}$ & 9525 & $\mathrm{n} / \mathrm{a}$ \\
\hline Installation Cost $(\$)$ & $\mathrm{n} / \mathrm{a}$ & 3633 & $\mathrm{n} / \mathrm{a}$ \\
\hline Payback Period (yrs) & $\mathrm{n} / \mathrm{a}$ & 0.38 & $\mathrm{n} / \mathrm{a}$ \\
\hline
\end{tabular}

The CHP unit used for the center is considered to have an overall efficiency of $70 \%$ because most of the CHP units have an efficiency of 70 to $80 \%$. As per [44] energy saved is 305,000 $\mathrm{kWh} / \mathrm{yr}$, which when converted is 991395.24 cu.ft/yr. When calculating the \% difference of results it is found to be $3.92 \%$. As per [44] money saved is in British-pounds so the other sections are ignored. 


\section{Conclusion:}

The results obtained in the test cases gave a difference of less than $10 \%$ with those of WVU's. With the percentage difference it can be stated that the expert system is reliable. The expert system program gives the West Virginia school boards the energy and money saved, cost for installation and payback period by installing each energy efficiency option, and according to which the school board can make their own decisions whether or not to invest on the renovation. In West Virginia the payback period should be 10 years and below with this into consideration most of the options present in the expert system have a payback period less than 10 years. There are certain options which have minimal to no installation costs with which the schools could save energy and also money, using the money saved they can reinvest on other energy saving options. Since the funds needed for school to invest on renovations take time to be released, these minimal energy saving options can save money and add up to the installation costs. The Water saved by the options can also add to the money saved which is not added in the expert system and can also fetch LEED credits for saving water. The expert system also provides the technical expertise about ENERGY STAR, ASHRAE 90.1 and AEDG K-12 Schools recommendations for energy saving options. The MATLAB GUI can be easily converted into the .NET or com file and taking this point into consideration the expert system can be deployed on WVU's College of Engineering and Mineral Resources (CEMR) Website. 
12. Future Work:

The scope for future work on this expert system can be extended to a variety of scenarios which are

- Any new type of energy saving options which are not included can be easily added to the expert system.

- In the energy saving options the user can have more internal choices of material types.

- In the results section the user can also get the $\mathrm{CO}_{2}$ emissions reduction per year by installing the recommendations. 


\section{Bibliography:}

1. "ENERGY STAR ${ }^{\circledR ”}<$ http://www.ENERGYSTAR.gov/>

2. "ENERGY STAR ${ }^{\circledR}$ Building Upgrade Manual”, US EPA, Office of Air and Radiation 2008 Edition.

3. ASHRAE Standard 90.1-2007, American Society of Heating, Refrigeration and Air Conditioning Engineers, Atlanta, Georgia.

4. 2005 ASHRAE Handbook of Fundamentals, American Society of Heating, Refrigeration and Air Conditioning Engineers, Atlanta, Georgia.

5. Principles of Heating Ventilating and Air Conditioning, American Society of Heating, Refrigeration and Air Conditioning Engineers, Atlanta, Georgia.

6. Advanced Energy Design Guide for K-12 school Buildings, American Society of Heating, Refrigeration and Air Conditioning Engineers, Atlanta, Georgia.

7. Richard L. Routh, MAYNARD'S INDUSTRIAL ENGINEERING HANDBOOK, Chapter 12.5 "Artificial Intelligence and Knowledge Management Systems", 2004

8. Mehdi Sagheb-Tehrani, "The design process of expert systems development: some concerns", Expert Systems, May 2006, Vol. 23, No. 2.

9. Melissa L. Morris, "The Design of an Expert System to Aid in the Selection of a Wood Fired Boiler System", West Virginia University, 2008.

10. Ahmed, M., Gilman, D., Kim, s., Chongcharoensuk, C., Malhotra, M., Haberl, J., culp, C., "Development of a Web-based Emission Reduction Calculator for Code-Compliant Commercial Construction", Energy Systems Laboratory Report, ESL-IC-10/05-34, 2005. 
11. Jeff Habrel, Charles Culp, Bahman Yazdani, "Development of a Web-based CodeCompliant ASHRAE 90.1-1999 Commercial simulation for Texas", 2009 Building Simulation Conference, International Building Performance Simulation Association (IBPSA), July 27-30th, University of Strathclyde, Glasgow, Scotland.

12. Im, P and J.Haberl. "Analysis of the Energy saving Potential in K-5 Schools in Hot and Humid Climates", Proceedings of the Sixteenth Symposium on Improving Building Systems in Hot and Humid Climates, 2008b.

13. North Carolina Department of Public Instruction "Energy Guidelines for K-12 Public schools", 2009.

14. Heating Degree days, Cooling Degree days, <http://www.weatherdatadepot.com/>.

15. US DOE, EERE, "Energy Efficiency trends in Residential and Commercial Buildings", 2008.

16. Energy Management Guide for Schools, < http://www.need.org />.

17. Means, R.S. Building Construction Cost Data. $68^{\text {th }}$ Annual Edition, 2010.

18. Means, R.S. Mechanical Cost Data. $33^{\text {rd }}$ Annual Edition, 2010.

19. Means, R.S. Electrical Cost Data, $32^{\text {nd }}$ Annual Edition, 2009.

20. Chapter 15. "Aquaculture”, Kevin D. Rafferty, P.E. Geo-Heat Center Klamath Falls, OR., <http://0-www.osti.gov.iii-server.ualr.edu/geothermal/servlets/purl/895106Bx22q6/895106.pdf>.

21. Im, P and J.Haberl. "A survey of High Performance Schools". 2006, < http://wwwesl.tamu.edu/docs/terp/2006/ESL-HH-06-07-12.pdf >. 
22. Im, P and J.Haberl. "Development of a simplified simulation tool for high performance K5 schools in Hot and Humid climates", ESL-PA-08-08-06, Third National Conference of IBPSA-USA Berkeley, California, July 30 - August 1, 2008.

23. Im, P and J.Haberl. "Analysis of the Energy saving Potential in K-5 Schools in Hot and Humid Climates: Application of high performance measures and renewable energy systems". ESL-PA-10-08-05, 2010.

24. J.Haberl, C.Culp, B.Yazdani, H.kim, Z.Liu, J. Mukhopadhyay, S.Do, K.Kim, JC. Baltazar. "Energy Efficiency, Cost-Effectiveness, and Air pollutant reduction analysis from energy efficiency and renewable energy (EE/RE) Projects in Texas Public Schools". Energy Systems Laboratory, ESL-TR-10-08-01, 2010.

25. "Energy Efficiency Programs in K-12 schools", US EPA, 2011, <http://www.epa.gov/statelocalclimate/documents/pdf/k-12_guide.pdf>

26. Expert Systems, < http://www.wikipedia.org />.

27. MATLAB, < http://www. wikipedia.org />.

28. MATLAB, <http://www.mathworks.com/>.

29. Charleston Yeager Arpt Weather file, 724140,

<http://rredc.nrel.gov/solar/old_data/nsrdb/1991-

2005/tmy3/by_state_and_city.html\#W>.

30. Harrison Marion Rgn Weather file, 724175 ,

<http://rredc.nrel.gov/solar/old_data/nsrdb/1991-

2005/tmy3/by_state_and_city.html\#W>.

31. Caulking Gun and tube, < http://www.lowes.com/>. 
32. Bulbs and electronic ballasts, <http://www.bulbs.com/>.

33. Shower Heads, <http://www.sears.com/>.

34. Brasch Make-up Air unit, CASTO TECHNICAL SERVICES.

35. Electronic Ballast for MH 360 Watt Bulb, < http://www.elightbulbs.com/>.

36. UEI Combustion analyzer kit, < http://www.actoolsupply.com/>.

37. DOE-2, < http://doe2.com/>.

38. Water Science for Schools, <http://ga.water.usgs.gov/edu/sc4.html>.

39. ASHRAE 1987 HVAC Systems and Applications, Chapter 54, Table 54.4.

40. Kim, Jong-Jin and Moon, Jin Woo. "Impact of Insulation on Building Energy Consumption". Eleventh International IBPSA Conference, Glasgow, Scotland, July 27-30 2009.

41. Replace T12 fluorescent tubes with high performance T-8 lamps and electronic ballasts, $<$ http://www.ahla.com/Green.aspx?id=28815>.

42. Pipe Insulation Worksheet, Missouri Department of Natural Resources, <http: //dnr.mo.gov/forms/780-1362-f.pdf>.

43. Boiler Scale Formation and Efficiency Loss, <http://www.thermidaire.on.ca/bls.html>

44. Case Study 76, Energy Efficiency in sports and recreation buildings: swimming pool covers, <http://www.dgcommunity.net/dgcommunity/xdocuments/6107.pdf.ashx>

45. Economizer Cost, Jackson Heating and Air, LLC. , Morgantown. 
Appendix A: Expert System Software Code for Main Case and Roof Insulation 


\section{Main Case Program}

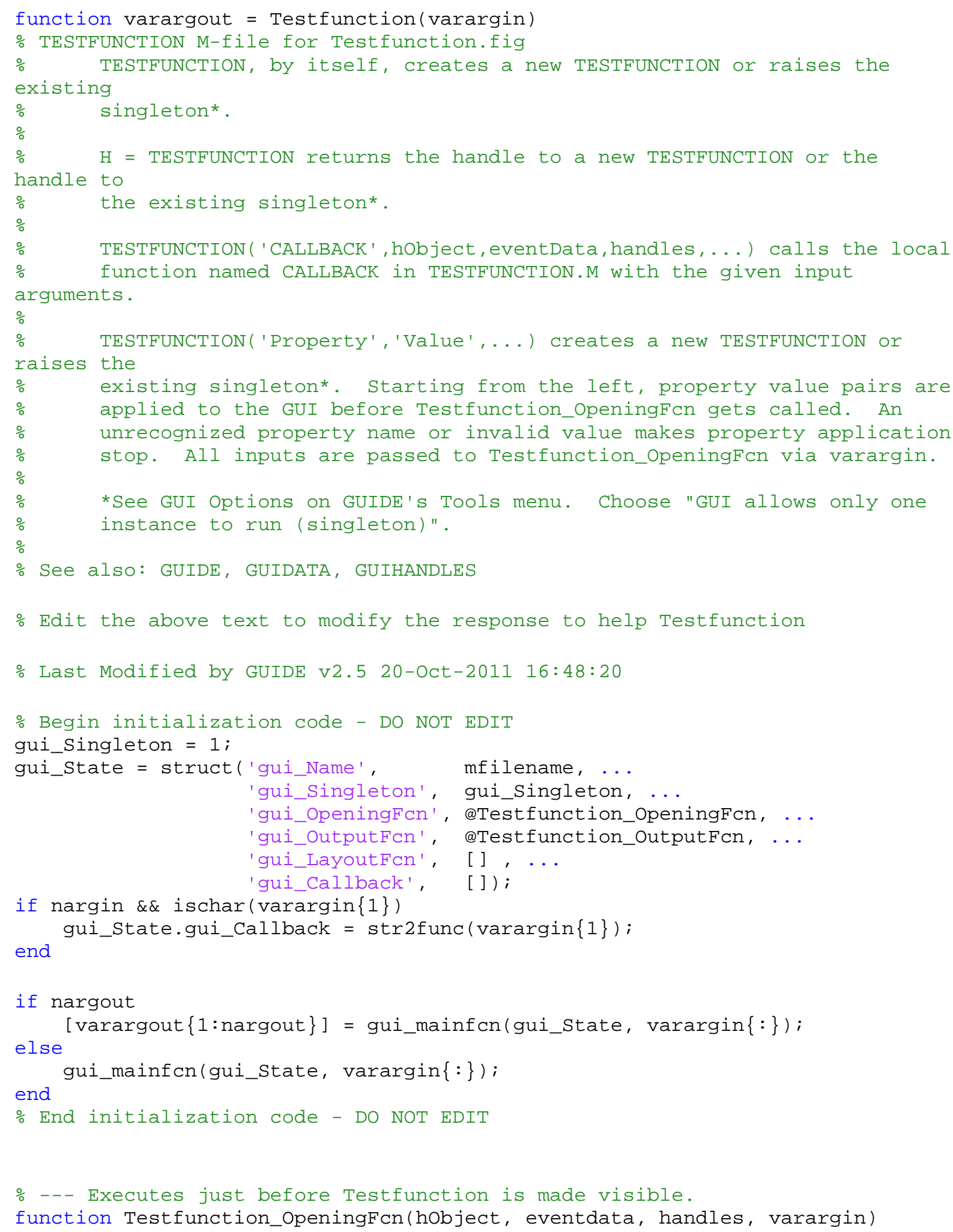


$\%$ This function has no output args, see OutputFcn.

$\%$ hobject handle to figure

$\%$ eventdata reserved - to be defined in a future version of MATLAB

$\%$ handles structure with handles and user data (see GUIDATA)

\% varargin command line arguments to Testfunction (see VARARGIN)

\% choose default command line output for Testfunction

handles. output $=$ hobject;

\% Update handles structure

guidata(hobject, handles);

\% UIWAIT makes Testfunction wait for user response (see UIRESUME)

$\%$ uiwait(handles.figure1);

\% -- Outputs from this function are returned to the command line.

function varargout = Testfunction_outputFcn(hobject, eventdata, handles)

$\%$ varargout cell array for returning output args (see VARARGOUT);

$\%$ hobject handle to figure

$\%$ eventdata reserved - to be defined in a future version of MATLAB

$\%$ handles structure with handles and user data (see GUIDATA)

\% Get default command line output from handles structure

varargout $\{1\}=$ handles . output;

\% --- Executes on selection change in listbox1.

function listbox1_Callback(hobject, eventdata, handles)

$\%$ hobject handle to listbox1 (see GCBO)

$\%$ eventdata reserved - to be defined in a future version of MATLAB

$\%$ handles structure with handles and user data (see GUIDATA)

$\%$ Hints: contents $=\operatorname{cellstr}($ get $($ hobject, 'String') $)$ returns listbox1 contents as cell array

\% contents $\quad$ get(hobject, 'Value')\} returns selected item from listbox1

listnames $=\operatorname{get}($ hobject, 'String');

listName $=$ listNames $($ get $($ hobject, 'Value' $))$;

if( $\operatorname{strcmp}$ (listName, 'Computer Low Power Mode')) M1;

elseif(strcmp(listName, 'Shower Heads ')) M2；

elseif( $\operatorname{strcmp}($ listName, 'Faucet(aerator) ' ))

M3;

elseif(strcmp(listname, 'Pool Covers')); M4;

elseif(strcmp(listName, 'Faucet Leaks'));

end M5;

\% --- Executes during object creation, after setting all properties. function listbox1_createFcn(hobject, eventdata, handles)

$\%$ hobject handle to listbox1 (see GCBO)

$\%$ eventdata reserved - to be defined in a future version of MATLAB

$\%$ handles empty - handles not created until after all createfcns called 
\% Hint: listbox controls usually have a white background on Windows. $\% \quad$ See ISPC and COMPUTER.

if ispc \&\& isequal(get(hobject, 'BackgroundColor'),

get $(\Theta$, 'defaultUicontrolBackgroundColor' $)$ )

end

set(hobject, 'BackgroundColor', 'white');

$\%$-- Executes on selection change in SWH.

function SWH_Callback(hobject, eventdata, handles)

$\%$ hobject handle to SWH (see GCBO)

$\%$ eventdata reserved - to be defined in a future version of MATLAB

$\%$ handles structure with handles and user data (see GUIDATA)

$\%$ Hints: contents $=\operatorname{cellstr}($ get $($ hobject, 'String') $)$ returns SWH contents as cell array

$\% \quad$ contents $\{$ get(hobject, 'Value')\} returns selected item from SWH

listNames $=\operatorname{get}($ hobject, 'String');

listName $=$ listNames $($ get $($ hobject, 'Value' $))$;

if (strcmp(listName, 'Excess Oxygen Sensor'))

S1;

elseif(strcmp(listName, 'Heater Insulation'))

$\mathrm{S} 2$;

elseif( $\operatorname{strcmp}($ listName, 'Instantaneous Heater'))

S3;

elseif(strcmp(listName, 'Water Heater Efficiency'))

S4;

elseif(strcmp(listName, 'Boiler Maintenance'))

S5;

elseif(strcmp(listName, 'Water Temperature'))

S6;

elseif(strcmp(listName, 'Pipe Insulation'))

end

S7;

\% --- Executes during object creation, after setting all properties.

function SWH_CreateFcn(hobject, eventdata, handles)

$\%$ hobject handle to SWH (see GCBO)

$\%$ eventdata reserved - to be defined in a future version of MATLAB

$\%$ handles empty - handles not created until after all createFcns called

\% Hint: listbox controls usually have a white background on Windows.

$\% \quad$ See ISPC and COMPUTER.

if ispc \&\& isequal(get(hobject, 'BackgroundColor'),

$\operatorname{get}(0$, 'defaultUicontrolBackgroundColor' $))$

end set(hobject, 'BackgroundColor', 'white');

$\%$-- Executes on selection change in HVAC.

function HVAC_Callback(hobject, eventdata, handles)

$\%$ hobject handle to HVAC (see GCBO)

$\%$ eventdata reserved - to be defined in a future version of MATLAB

$\%$ handles structure with handles and user data (see GUIDATA) 
$\%$ Hints: contents $=\operatorname{cellstr}($ get (hobject, 'String')) returns HVAC contents as cell array

\% contents\{get(hobject, 'Value')\} returns selected item from HVAC

listNames $=$ get $($ hobject, 'String');

listName $=$ listNames $($ get $($ hobject, 'Value' $))$;

if( $\operatorname{strcmp}($ listName, 'Duct Insulation'))

$\mathrm{H} 1$;

elseif(strcmp(listName, 'Cooling SEER')) $\mathrm{H} 2$;

elseif(strcmp(listName, 'Amount of ventilation Air Needed')) H3;

elseif(strcmp(listName, 'Shut off Electric Reheat Systems')) $\mathrm{H} 4$;

elseif( $\operatorname{strcmp}($ listName, 'Economiser' $)$ ) H5;

elseif(strcmp(listName, 'Staged Make-up Air Unit')) $\mathrm{H} 6$;

elseif(strcmp(listName, 'Setback Controls')) $\mathrm{H} 7$;

elseif(strcmp(listName, 'HVAC Maintenance'))

end $\mathrm{H} 8$;

\% --- Executes during object creation, after setting all properties. function HVAC_CreateFcn(hobject, eventdata, handles)

$\%$ hobject handle to HVAC (see GCBO)

$\%$ eventdata reserved - to be defined in a future version of MATLAB

$\%$ handles empty - handles not created until after all createFcns called

\% Hint: listbox controls usually have a white background on Windows.

$\% \quad$ See ISPC and COMPUTER.

if ispc \&\& isequal(get(hobject, 'BackgroundColor'),

$\operatorname{get}(\odot$, 'defaultUicontrolBackgroundColor' $))$

end

set(hobject, 'BackgroundColor', 'white');

$\%$-- Executes on selection change in lighting.

function lighting_Callback(hobject, eventdata, handles)

$\%$ hobject handle to lighting (see GCBO)

$\%$ eventdata reserved - to be defined in a future version of MATLAB

$\%$ handles structure with handles and user data (see GUIDATA)

$\%$ Hints: contents $=$ cellstr $($ get $($ hobject, 'String') $)$ returns lighting contents as cell array

\% contents $\quad$ get(hobject, 'Value')\} returns selected item from lighting listNames $=\operatorname{get}($ hobject, 'String');

listName $=1$ istNames $($ get $($ hobject, 'Value' $))$;

if(strcmp(listName, 'T12 96Watts Magnetic to T8 59Watts Electronic')) L1;

elseif(strcmp(listName, 'T12 40Watts Magnetic to T8 32Watts Electronic')) L2;

elseif(strcmp(listName, 'T12 40Watts Magnetic to T8 28Watts Electronic')) L3;

elseif(strcmp(listName, 'T12 40Watts Magnetic to T8 25Watts Electronic')) L4; 


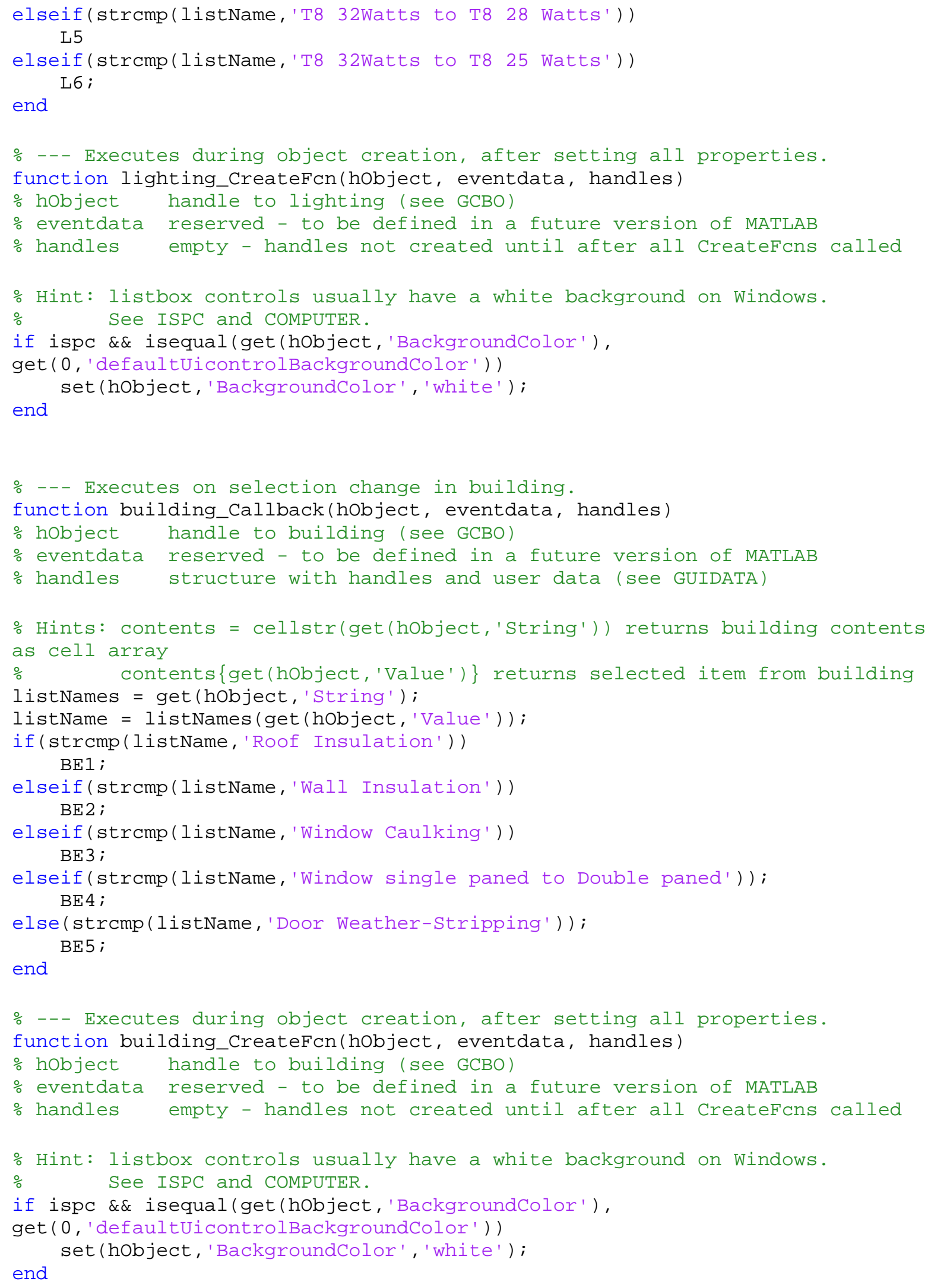


$\%$--- Executes on button press in BE.

function BE_Callback(hobject, eventdata, handles)

$\%$ hobject handle to BE (see GCBO)

$\%$ eventdata reserved - to be defined in a future version of MATLAB

$\%$ handles structure with handles and user data (see GUIDATA)

\% Hint: get(hobject, 'Value') returns toggle state of BE

handles.output = hobject;

guidata(hobject, handles);

set (handles.building, 'Visible', 'on');

\%set (handles.text1, 'Visible', 'on');

set (handles. listbox7, 'Visible', 'on');

set (handles.listbox8, 'Visible', 'off');

set (handles. listbox9, 'Visible', 'off');

set (handles.listbox10, 'Visible', 'off');

set (handles. listbox11, 'Visible', 'off');

set (handles. Mainlight, 'Visible', 'off');

set (handles. HVAC, 'Visible', 'off');

\%set (handles. text3, 'Visible', 'off');

set (handles. SWH, 'Visible', 'off');

set (handles. listbox1, 'Visible', 'off');

set (handles.text9, 'Visible', 'on');

set (handles. lighting, 'Visible', 'off');

set (handles. lighting2, 'Visible', 'off');

set (handles. lighting3, 'Visible', 'off');

if get (handles.BE, 'Value')

set (handles. Light, 'Value ', 0 );

set (handles. Hvac, 'Value', $\Theta$ );

set (handles. Swh, 'Value', $\odot$ );

else

set (handles. Misc, 'Value', $\odot$ );

end

set (handles. BE, 'Value', 1);

listNames $=\operatorname{get}($ hobject, 'String');

listName $=$ listNames $($ get $($ hobject, 'Value' $))$;

if strcmp(listName, 'Building Envelope Savings')

end building;

\% --- Executes on button press in Light.

function Light_Callback(hobject, eventdata, handles)

$\%$ hobject handle to Light (see GCBO)

$\%$ eventdata reserved - to be defined in a future version of MATLAB

$\%$ handles structure with handles and user data (see GUIDATA)

\% Hint: get(hobject, 'Value') returns toggle state of Light

handles. output = hobject;

guidata(hobject, handles);

set (handles. Mainlight, 'Visible', 'on');

set (handles.building, 'Visible', 'off');

set (handles. listbox7, 'Visible', 'off');

set (handles. listbox8, 'Visible', 'on');

set (handles. listbox9, 'Visible', 'off'); 


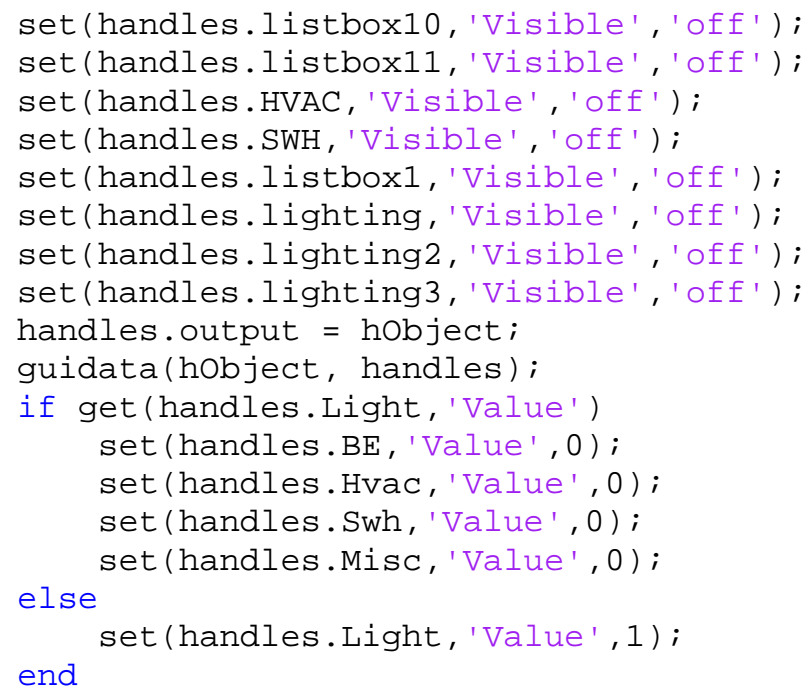

$\%$-- Executes on button press in Swh.

function Swh_Callback(hobject, eventdata, handles)

$\%$ hobject handle to Swh (see GCBO) 
\% eventdata reserved - to be defined in a future version of MATLAB $\%$ handles structure with handles and user data (see GUIDATA)

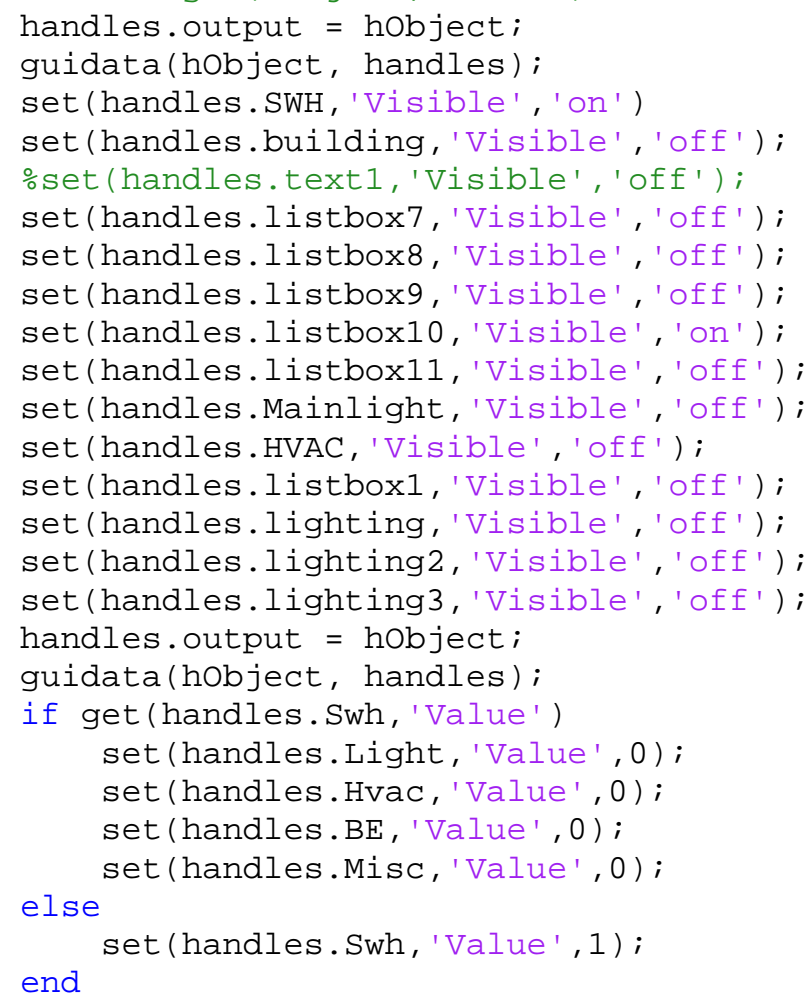




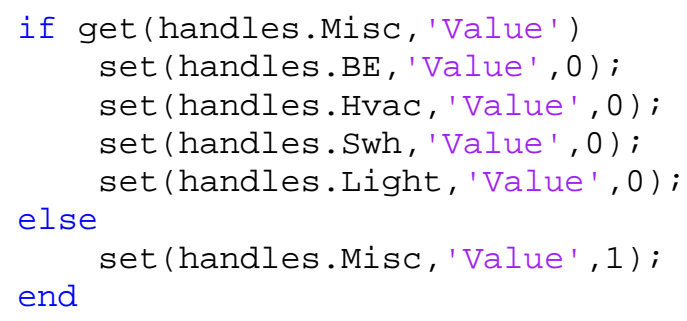




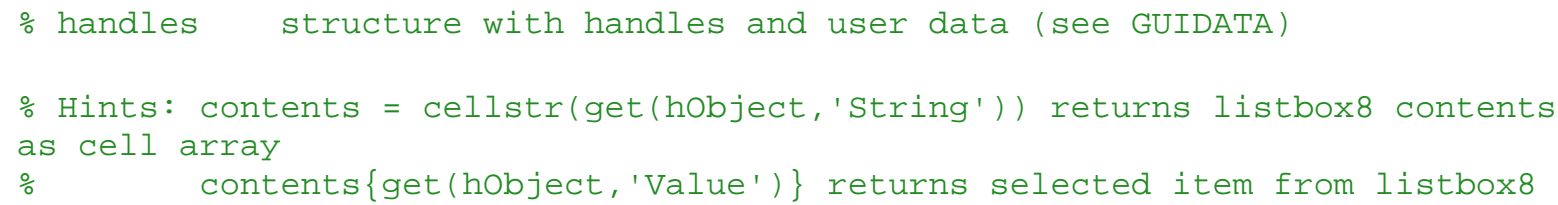




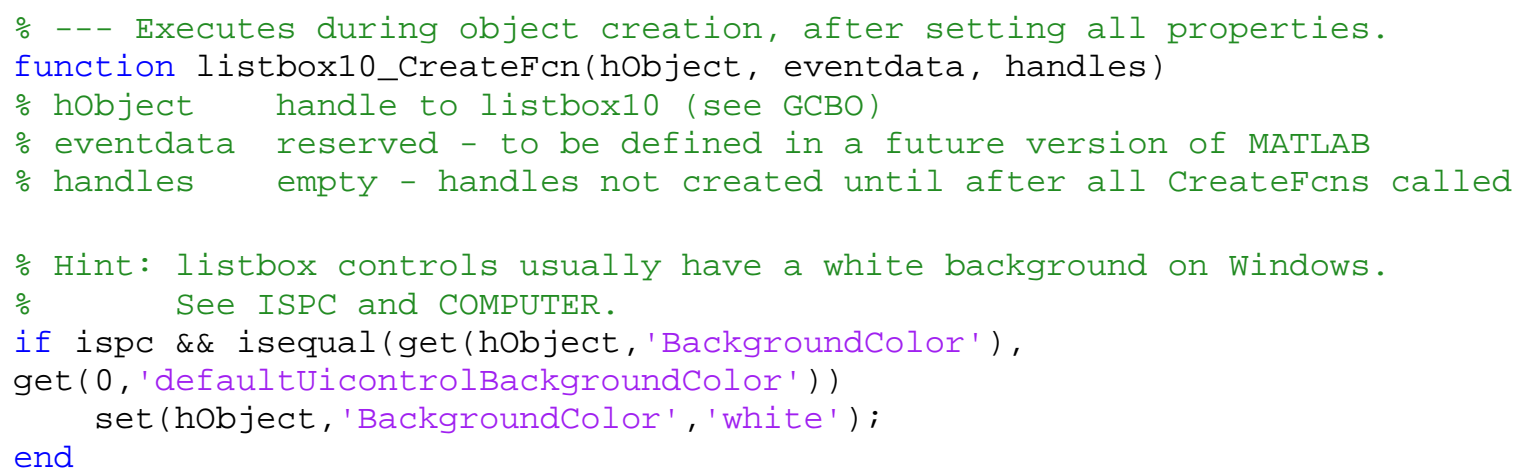

\% -- Executes on selection change in listbox11.

function listbox11_Callback(hobject, eventdata, handles)

$\%$ hobject handle to listbox11 (see GCBO)

$\%$ eventdata reserved - to be defined in a future version of MATLAB

$\%$ handles structure with handles and user data (see GUIDATA)

\% Hints: contents $=\operatorname{cellstr}($ get $($ hobject, 'String') $)$ returns listbox 11 contents as cell array

$\% \quad$ contents $\{$ get(hobject, 'Value')\} returns selected item from listbox11

\% -- Executes during object creation, after setting all properties.

function listbox11_CreateFcn(hobject, eventdata, handles)

$\%$ hobject handle to listbox11 (see GCBO)

$\%$ eventdata reserved - to be defined in a future version of MATLAB

$\%$ handles empty - handles not created until after all createFcns called

\% Hint: listbox controls usually have a white background on Windows.

$\% \quad$ See ISPC and COMPUTER.

if ispc \&\& isequal(get(hobject, 'BackgroundColor'),

$\operatorname{get}(\odot$, 'defaultUicontrolBackgroundColor' $))$ end

set(hobject, 'BackgroundColor', 'white');

\% --- Executes on selection change in Mainlight.

function Mainlight_Callback(hobject, eventdata, handles)

$\%$ hobject handle to Mainlight (see GCBO)

$\%$ eventdata reserved - to be defined in a future version of MATLAB

$\%$ handles structure with handles and user data (see GUIDATA)

\% Hints: contents $=\operatorname{cellstr}($ get $($ hobject, 'String') $)$ returns Mainlight contents as cell array

$\% \quad$ contents $\{$ get(hobject, 'Value')\} returns selected item from Mainlight

listnames = get (hobject, 'String');

listName $=$ listNames $($ get $($ hobject, 'Value' $))$;

if(strcmp(listName, ' Fluorescent Lighting')) 


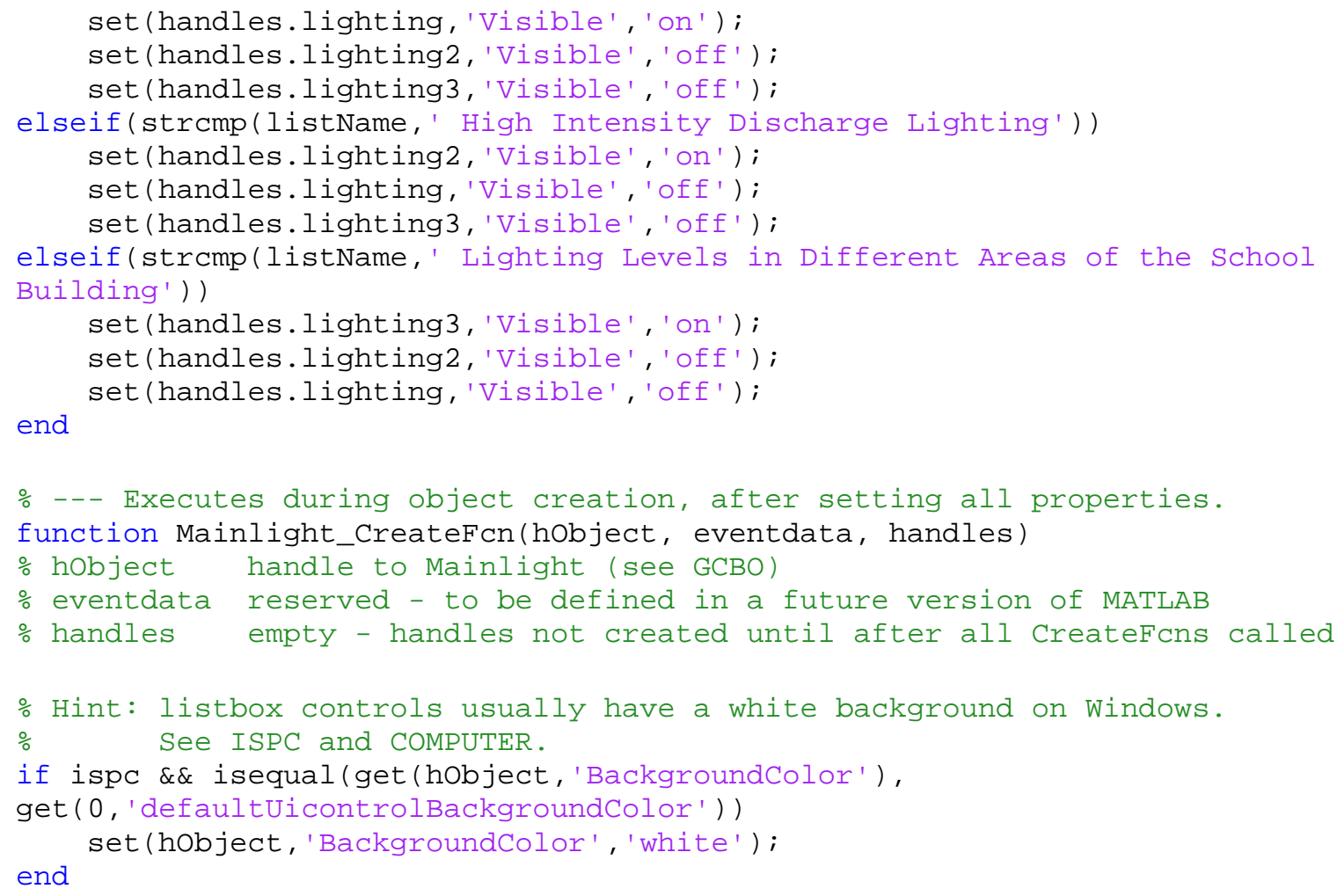


end

set(hobject, 'BackgroundColor', 'white');

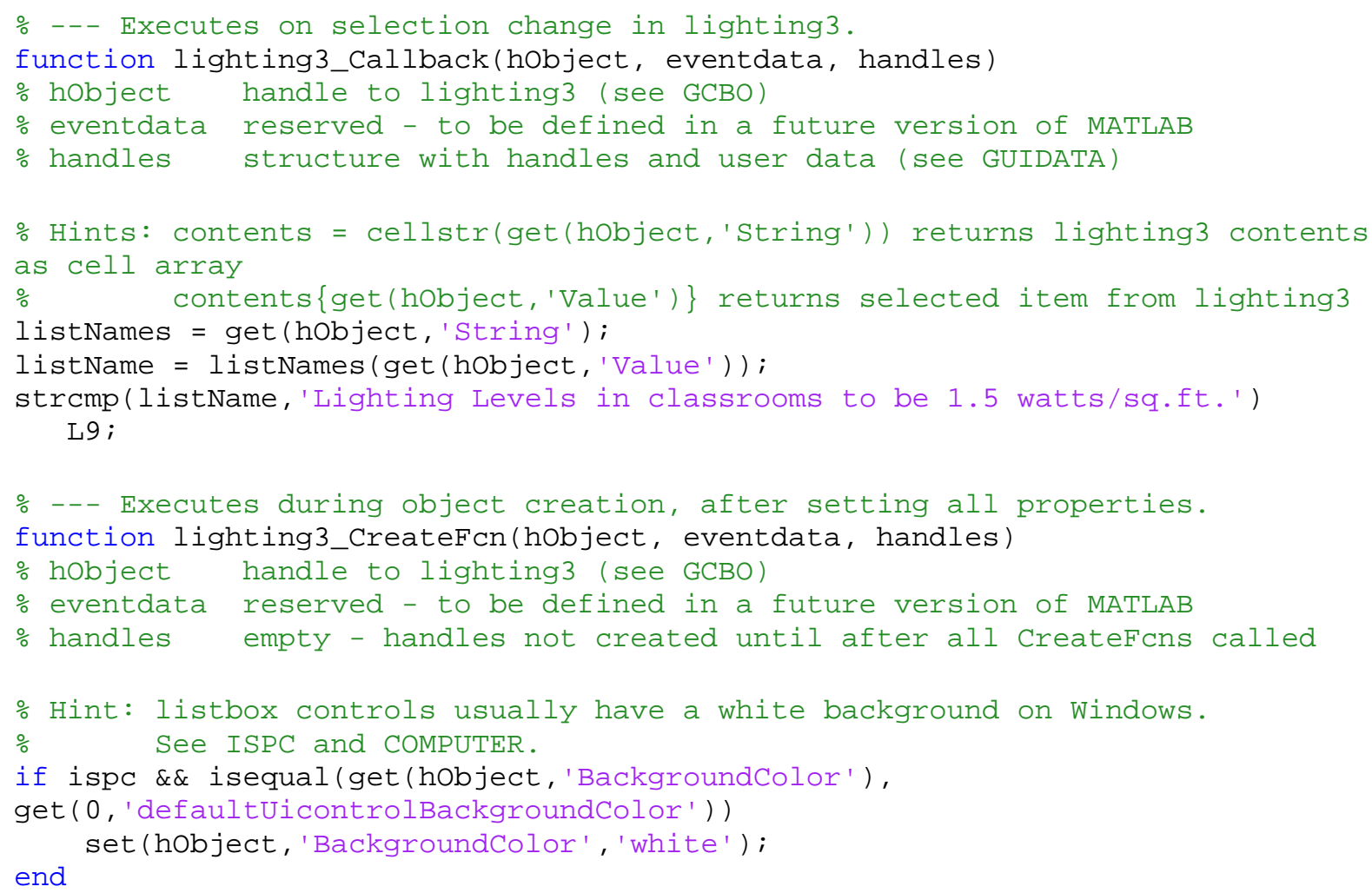




\section{Roof Insulation}

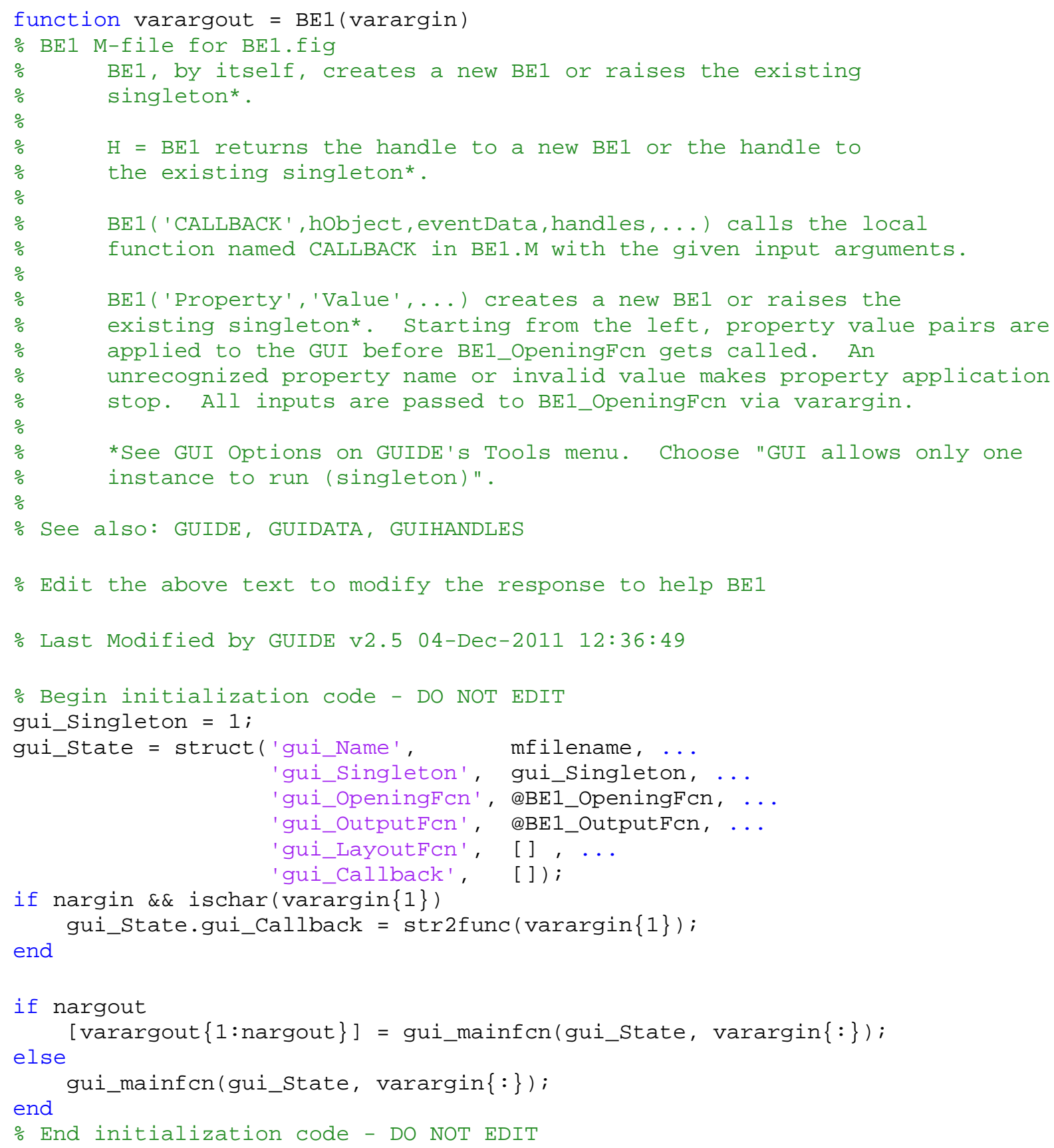


\% --- Executes just before BE1 is made visible.

function BE1_openingFcn(hobject, eventdata, handles, varargin)

$\%$ This function has no output args, see OutputFcn.

$\%$ hobject handle to figure

$\%$ eventdata reserved - to be defined in a future version of MATLAB

$\%$ handles structure with handles and user data (see GUIDATA)

\% varargin command line arguments to BE1 (see VARARGIN)

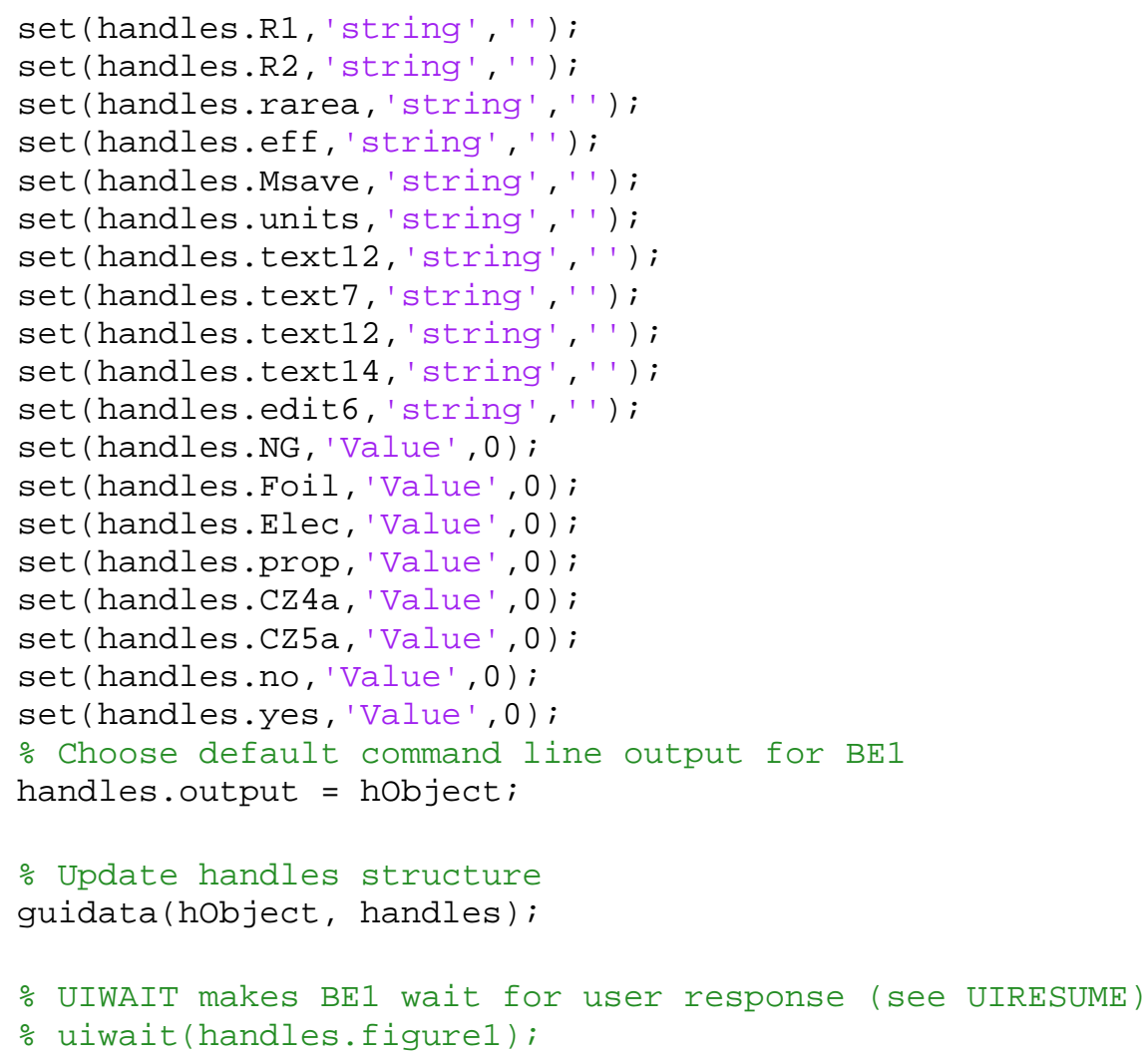




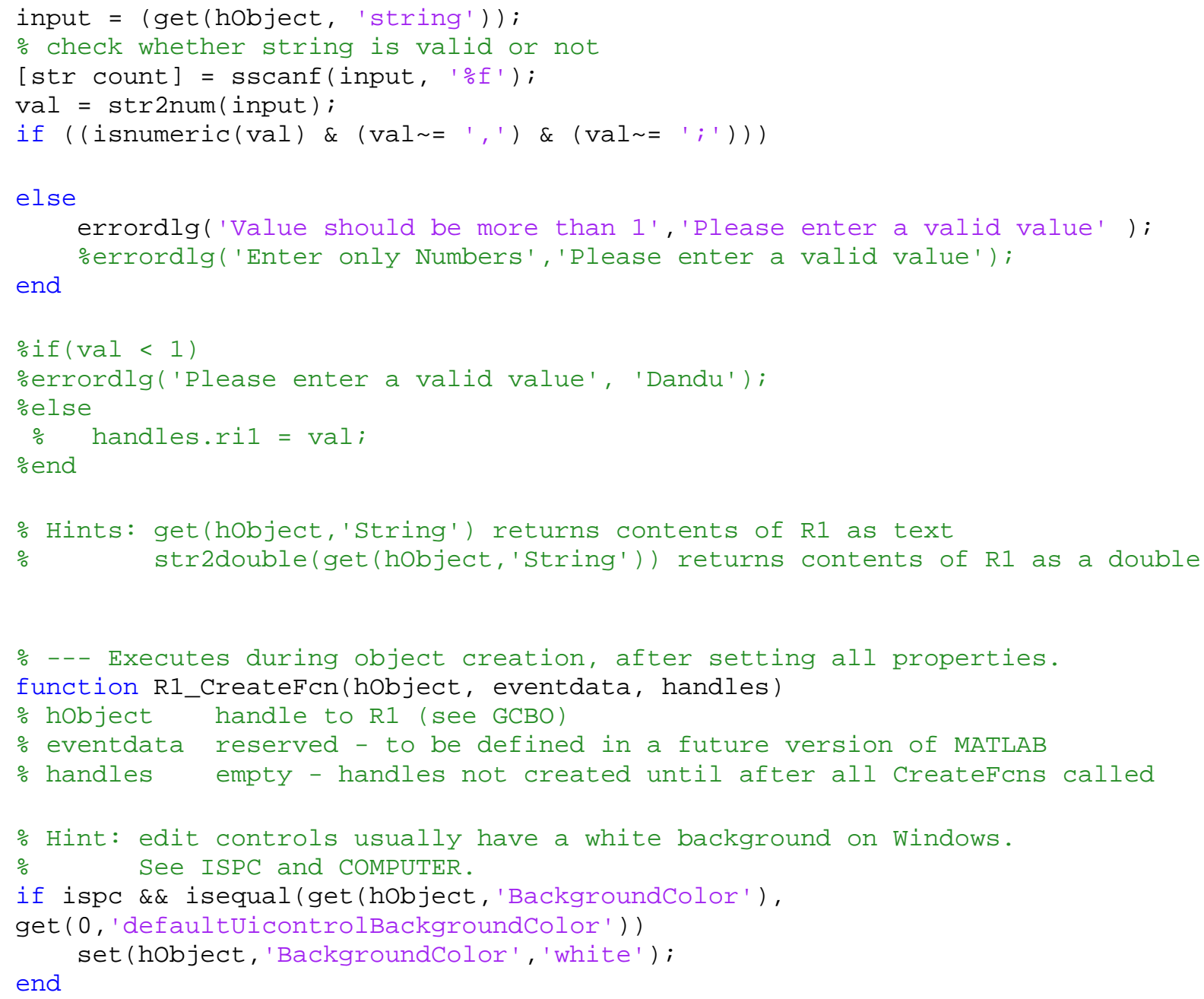


$\%$-- Executes during object creation, after setting all properties. function R2_CreateFcn(hobject, eventdata, handles)

$\%$ hobject handle to R2 (see GCBO)

$\%$ eventdata reserved - to be defined in a future version of MATLAB

$\%$ handles empty - handles not created until after all createFcns called

\% Hint: edit controls usually have a white background on Windows.

$\% \quad$ See ISPC and COMPUTER.

if ispc \&\& isequal(get(hobject, 'BackgroundColor'),

get $(\Theta$, 'defaultUicontrolBackgroundColor' $)$ )

end

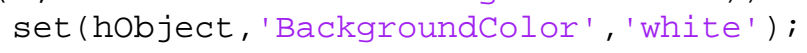




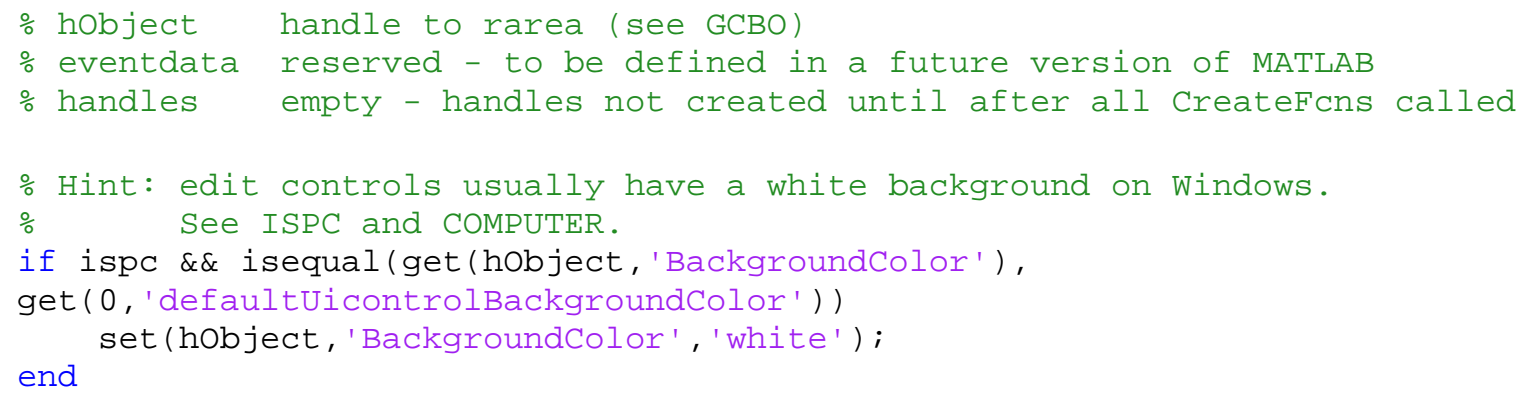




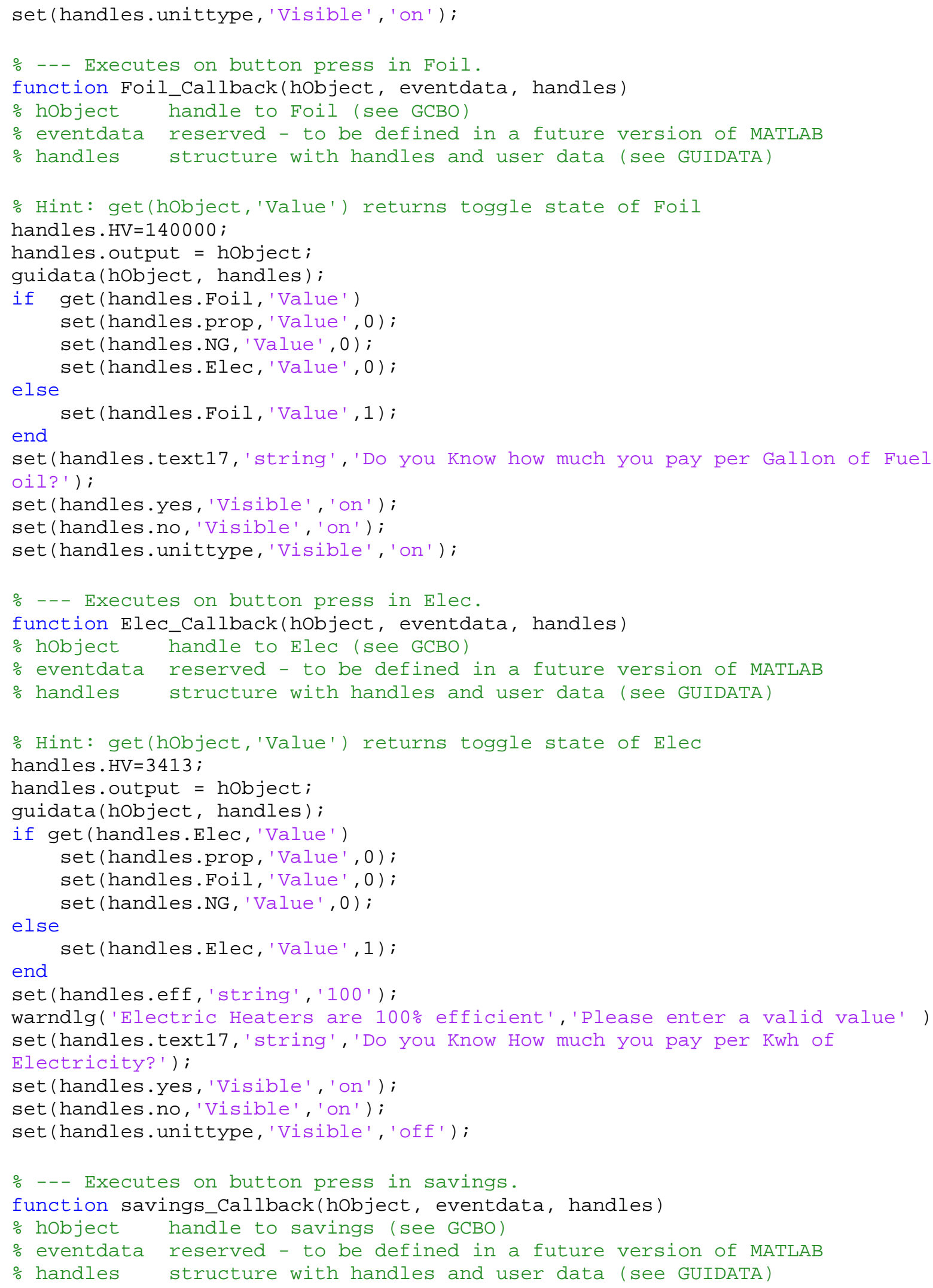




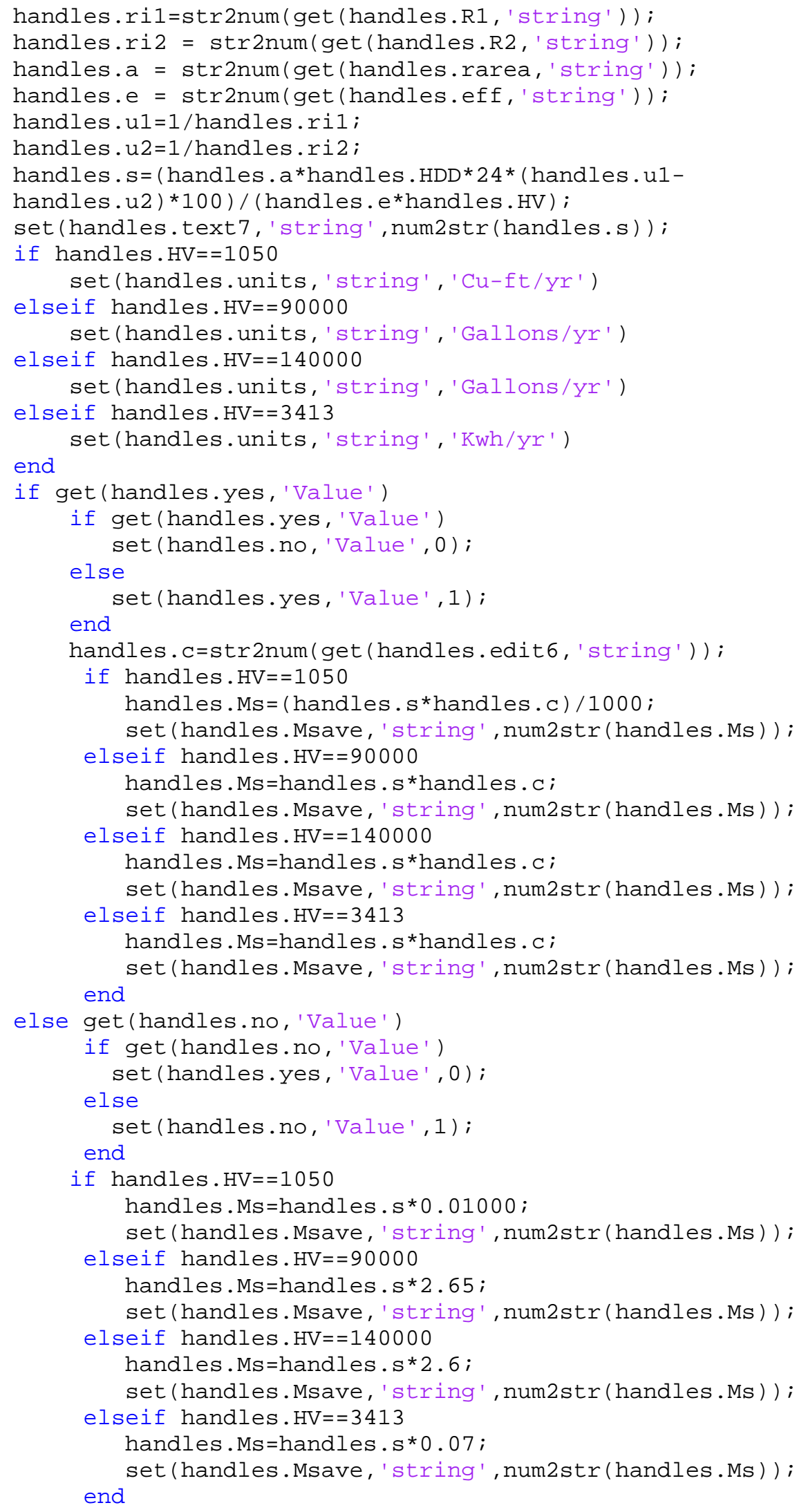




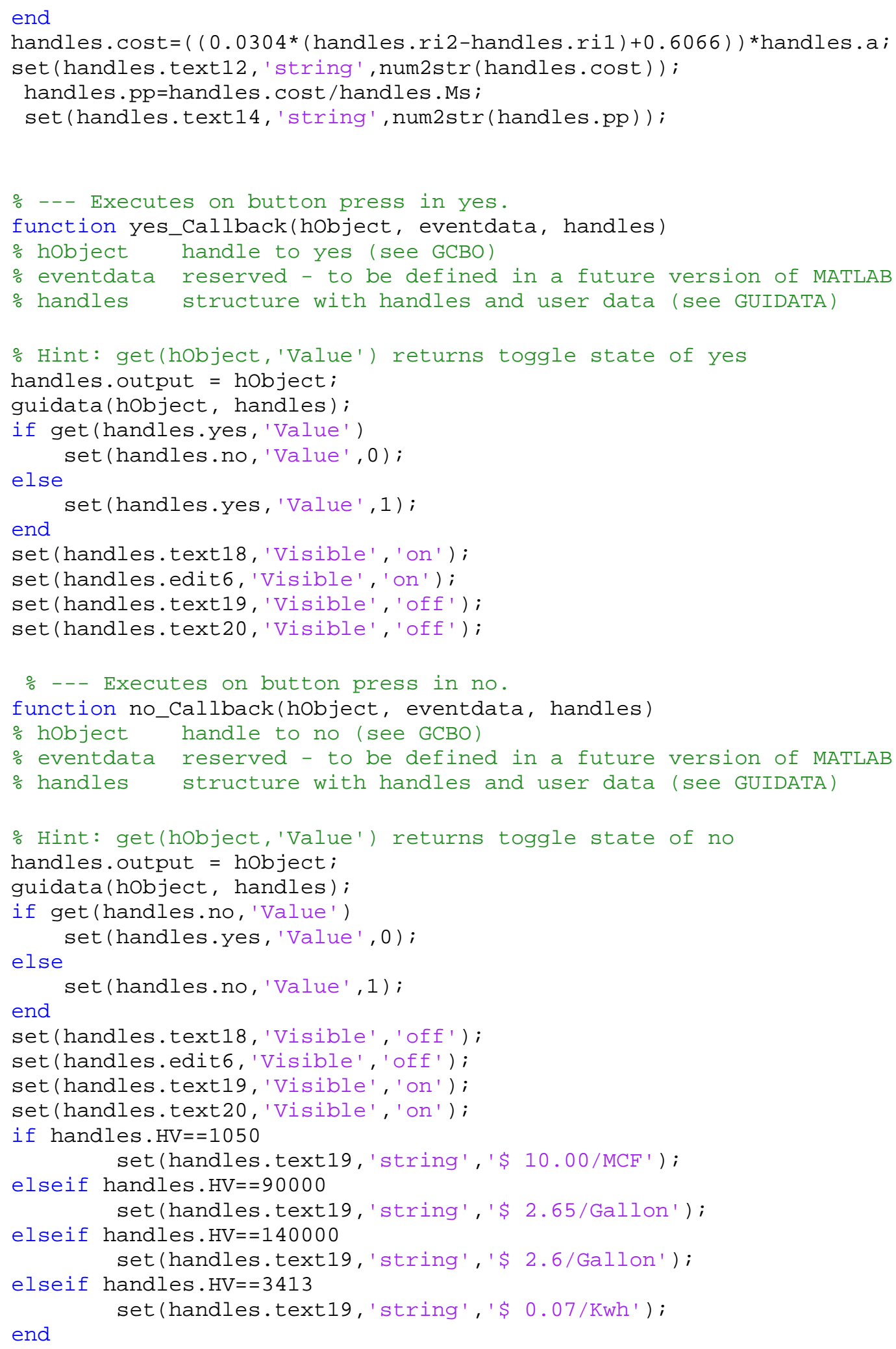




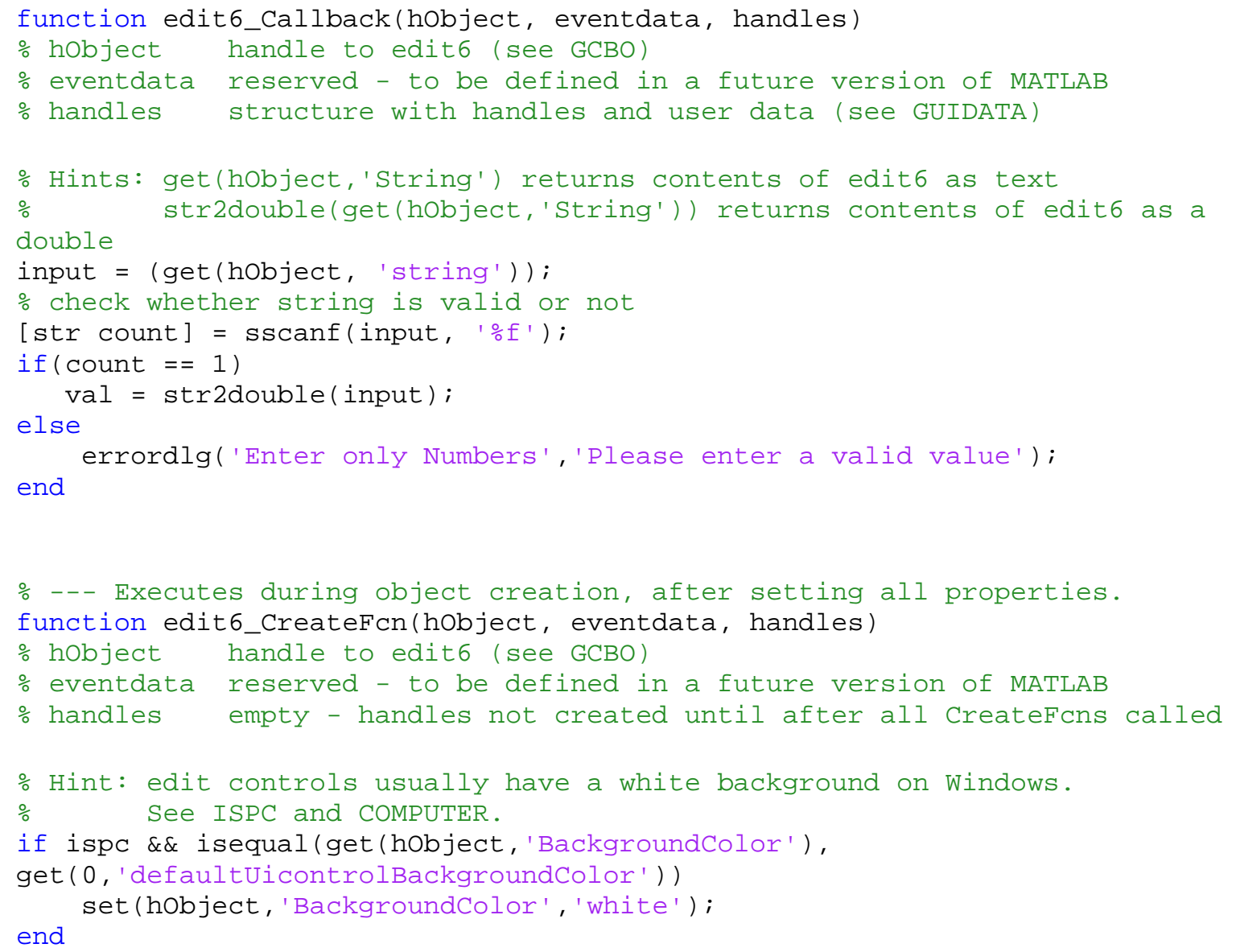


end

set (handles.Flatroof, 'Value', 1);

set (handles . popupmenu1, 'Visible', 'off' )

set (handles. popupmenu2, 'Visible', 'on')

\% - - Executes on button press in Pitchroof.

function Pitchroof_Callback(hobject, eventdata, handles)

$\%$ hobject handle to Pitchroof (see GCBO)

$\%$ eventdata reserved - to be defined in a future version of MATLAB

$\%$ handles structure with handles and user data (see GUIDATA)

\% Hint: get(hobject, 'Value') returns toggle state of Pitchroof

handles.output $=$ hobject;

guidata(hobject, handles);

if get (handles.Pitchroof, 'Value')

else

set (handles. Flatroof, 'Value', $\odot$ );

end

set (handles. Pitchroof, 'Value', 1);

set (handles . popupmenu1, 'Visible', 'on')

set (handles. popupmenu2, 'Visible', 'off' )

\% --- Executes on selection change in popupmenu1.

function popupmenu1_Callback(hobject, eventdata, handles)

$\%$ hobject handle to popupmenu1 (see GCBO)

$\%$ eventdata reserved - to be defined in a future version of MATLAB

$\%$ handles structure with handles and user data (see GUIDATA)

\% Hints: contents $=\operatorname{cellstr}($ get $($ hobject, 'String') $)$ returns popupmenu1

contents as cell array

$\% \quad$ contents\{get(hobject, 'Value')\} returns selected item from popupmenu1

listNames = get(hobject, 'String');

listName $=$ listNames $($ get $($ hobject, 'Value' $))$;

if(strcmp(listName, '1. Asphalt Shingles, 0.75" Wood, Air Film, Air Film,

0.75 " Wood, Plaster Board'))

set (handles.R1, 'string ', '4.29')

elseif(strcmp(listName,'2. Option 1+ 3" batt Insulation')) set (handles.R1, 'string', '15.29')

elseif(strcmp(listName, '3. Option 1+ 4" batt Insulation')) set (handles.R1, 'string ', '18.29')

elseif(strcmp(listName, '4. Option 1+6" batt Insulation')) set (handles.R1, 'string ', '23.29')

elseif(strcmp(listName, '5. Option 1+6.5" batt Insulation')) set (handles.R1, 'string', '25.29')

elseif(strcmp(listName, '6. Option 1+ 9" batt Insulation')) set (handles.R1, 'string ', '34.29' )

elseif ( strcmp (listName, Pitched Roof types')) set (handles.R1, 'string', ' ')

end

if get (handles. popupmenu1, 'Visible') else set (handles. popupmenu2, 'Visible', 'off') end set (handles . popupmenu1, 'Visible', 'on ') 


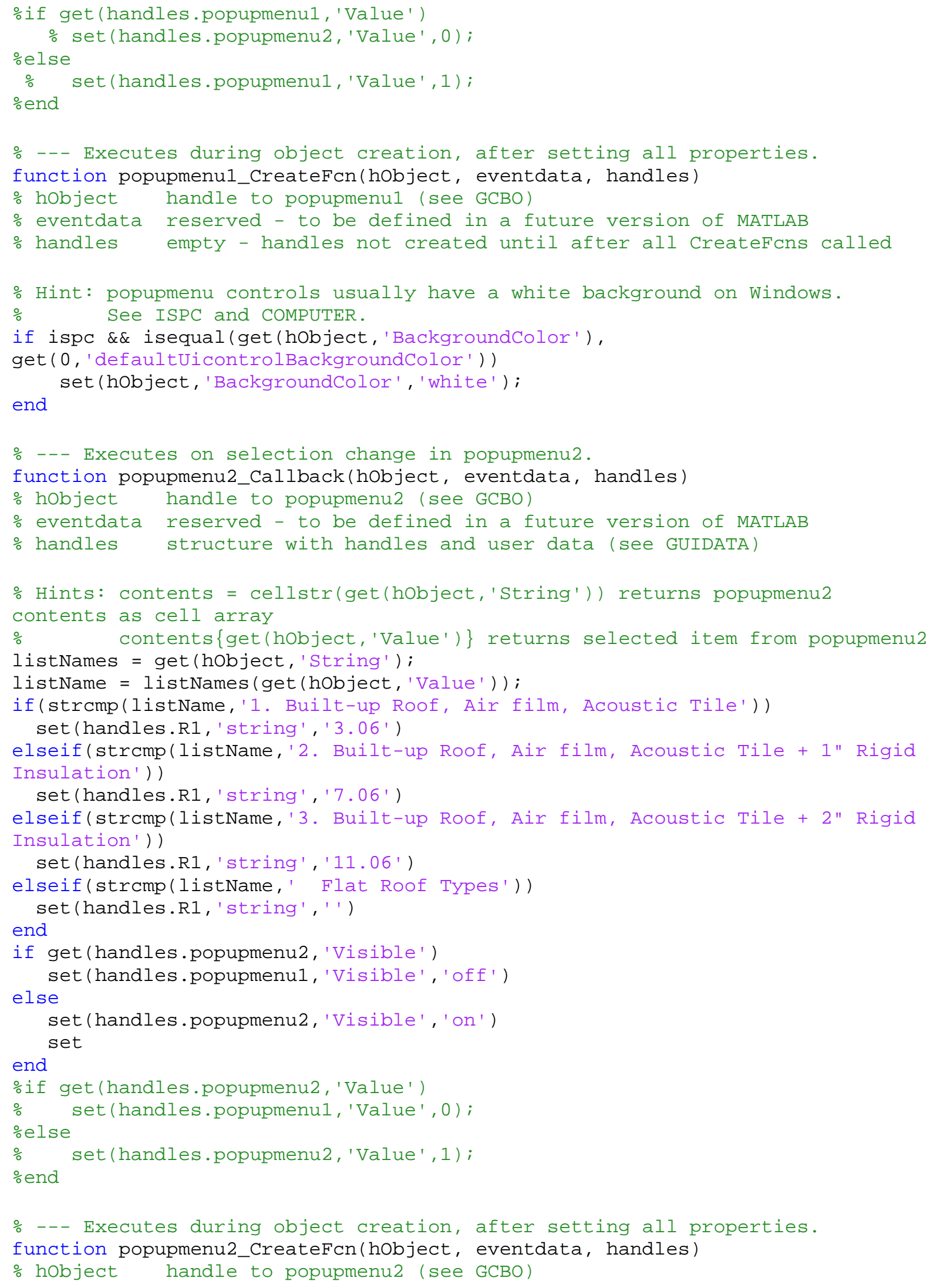


$\%$ eventdata reserved - to be defined in a future version of MATLAB

$\%$ handles empty - handles not created until after all createFcns called

\% Hint: popupmenu controls usually have a white background on Windows.

$\% \quad$ See ISPC and COMPUTER.

if ispc \&\& isequal(get(hobject, 'BackgroundColor'),

$\operatorname{get}(\Theta$, 'defaultUicontrolBackgroundColor' $)$ )

end

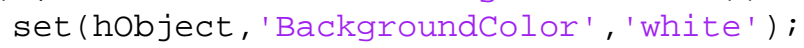




\section{ENERGY SAVING EXPERT SYSTEM FOR WEST VIRGINIA K-12 SCHOOLS \\ Karthik Reddy Dandu \\ Thesis Submitted to the College of Engineering and Mineral Resources at West Virginia University \\ in partial fulfillment of the requirements}

for the degree of

Master of Science

In

Mechanical Engineering

Department of Mechanical and Aerospace Engineering

APPROVAL OF THE EXAMINING COMMITTEE

Dr. Kenneth H. Means, Ph.D., P.E.

Dr. Larry E. Banta, Ph.D., P.E.

Dr. Bhaskaran Gopalakrishnan, Ph.D., P.E., CEM

\footnotetext{
John H. 